EQL Memo No. 21

\title{
COST ESCALATION IN NUCLEAR POWER
}

\author{
by \\ W. DAVID MONTGOMERY \\ and \\ JAMES P. QUIRK
}

EQL MEMORANDUM NO. 21

\begin{abstract}
January 1978
ENVIRONMENTAL ENGINEERING

LISRAPY (13B-78)

136 W. M. KECK LABOPATORY

California Institute of Technology

Pasadona, Calíomia 91125 U.S.A.
\end{abstract}

\section{Environmental Quality Laboratory CALIFORNIA INSTITUTE OF TECHNOLOGY \\ Pasadena, California 91125}




\title{
COST ESCALATION IN NUCLEAR POWER
}

$$
\text { by }
$$

W. David Montbmery

$$
\text { and }
$$

James P. Quirk

EQL MEMORANDUM NO. 21

January 1978

\author{
Sponsored by \\ National Science Foundation \\ Grant No. APR-75-16566 AOI \\ and \\ Energy Research and Development Administration \\ Grant No. EY-76-G-03-1305
}


ABSTRACT

This report is concerned with the escalation of capital costs of nuclear central station power plants between the early $1960 \mathrm{~s}$ and the present. The report presents an historical overview of the development of the nuclear power industry and cost escalation in the industry, using existing data on orders and capita1 costs. New data are presented on regulatory delays in the licensing process, derived from a concurrent study being carried on in the Social Science group at Caltech.

The conclusions of the study are that nuclear capital costs have escalated more rapidly than the GNP deflator or the construction industry price index. Prior to 1970 , cost increases are related to bottleneck problems in the nuclear construction and supplying industries and the regulatory process; intervenors play only a minor role in cost escalation. After 1970, generic changes introduced into the licensing process by intervenors (including environmental impact reviews, antitrust reviews, more stringent safety standards) dominate the cost escalation picture, with bottlenecks of secondary importance. Recent increases in the time from application for a construction permit to commercial operation are related not only to intervenor actions, but also to suspensions, cancellations or postponements of construction by utilities due to unfavorable demand or financing conditions. 
CONTENTS

$\frac{\text { Page }}{1}$ EXECUTIVE SUMMARY AND CONCLUSTONS . . . . . . . . . . . 1 BACKGROUND: THE GROWTH OF NUCLEAR POWER . . . . . . . . . 6 THE TURNKEY ERA: $1963-1966$. . . . . . . . .... 12 THE COMMERCIAL SUCCESS OF NUCLEAR POWER: 1966-1970 . . . . . 20 A TIME OF CHANGE: 1971-1976 ............... 36 CAUSES FOR NUCLEAR COST INCREASES . . . . . . . . . . . 43 OPERATING COSTS OF NUCLEAR AND COAL UNITS . . . . . . . . 52 FOOTNOTES ..................... 56 APPENDIX A: CAPITAL COST DATA FOR NUCLEAR UNITS . . . . . 61 APPENDIX B: DELAYS IN THE ISSUANCE OF CONSTRUCTION PERMIT FOR UNITS APPLYING FOR CONSTRUCTION PERMIT, 1966-1970 • • 70 APPENDIX C: SUSPENDED OR CANCELED NUCLEAR POWER PLANTS BETWEEN 1970-1977 WITH OUTSTANDING NSSS ORDER . . . . . . . 77 BIBLIOGRAPHY . . . . . . . . . . . . . . . . 94 
TABLES

Page

1 GROWTH OF NUCLEAR POWER • . . . . . . . . . . . 7

2 BACKLOGS IN THE LICENSING-CONSTRUCTION PROCESS
(UNITS IN EACH PROCESS AT END OF YEAR)

3 REPORTED CAPITAL COSTS OF NEW NUCLEAR UNITS, 1968-1976 • $~ 11$ FPC AND AEC/ERDA

4 AVERAGE ESTIMATED FINAL COST, \$/kw, AT SELECTED

POINTS IN TIME, FOR NUCLEAR UNITS UNDER • • • . 24 CONSTRUCTION, 1965-1975

5 CP APPLICÁtion, $1966,1968,1970$ •

6 REGULATORY TIME LAGS -- NUCLEAR LICENSING . • • . . 27-30

7 COMPARISON OF AVERAGE INITIAL ESTIMATES TO ESTIMATED AVERAGE ACTUAL COSTS OF NUCLEAR • • • • • 35 PLANTS BY YEAR OF ORDER

8 HISTORICAL CAPITAL COST DATA, 1968-1976 NUCLEAR AND COAL POWER PLANTS

9 PRICE INDICES AND INTEREST RATES, 1967-1976 • • • • . 44

10 CP APPLICATIONS, 1966-1970 . . . . . . . . . . . 49

11 HISTORICAL OPERATING COST COMPARISON, 1968-1973 . . . 54 NUCLEAR AND COAL POWER PLANTS

FIGURES

I ESTIMATED ACTUAL CAPITAL COSTS 1966-1976 • . • • . 23 
COST ESCALATION IN NUCLEAR POWER*

EXECUTIVE SUMMARY AND CONCLUSIONS

Rarely in the history of United States industry has there been a rags-to-riches-to-rags story as dramatic as that of the nuclear power industry. Just twenty years ago, the AEC was subsidizing the construction and operation of small prototype reactors, pursuing a goal mandated for it by the Atomic Energy Act of 1954, to promote a viable nuclear power industry. By the early 1960s, the technical capabilities of nuclear power had been demonstrated, but it was generally agreed within industry and the government that nuclear power would not be economically competitive with fossil fuel until the 70s. Then between 1963 and 1966, the two major reactor manufacturers, General Electric and Westinghouse, promoted nuclear power through fixed-price (turnkey) contracts at capital costs that made nuclear power competitive with coal for much of the nation. Orders for nuclear units soared during 1966 and 1967, followed by a trough in 1969. A second wave of orders hit the reactor manufacturers in the early 70s, peaking in 1973 .

*Research underlying this paper was supported in part under a grant from the National Science Foundation, APR-75-16566 AOI, in part under funds provided by the California Energy Commission and in part under funds provided by ERDA, EY-76-G-03-1305, EQL Block. 
Since 1974, there has been a drastic falling off of new orders accompanied by cancellations of existing orders to the point where net new orders, 1975-1976 totaled minus 9, with 8 additional cancellations in 1977.

Nuclear power which was originally hailed as the ultimate "clean" power source, has become highly controversial. In the mid-1960s the expansion of the nuclear power industry coincided with the growth of the environmental movement, leading to confrontations between utilities and intervenors in the nuclear licensing process. Safety issues and antitrust questions dominated the hearings up to the late 1960s. Then environmental issues came to the fore, leading to a restructuring of the licensing process following the Calvert Cliffs decision in 1971. But recently, an even more fundamental problem has hit the industry. Environmentalists and many neutral observors alike argue that even if nuclear units are safe, and even if nuclear power meets environmental standards, nonetheless nuclear units should not be built because they are simply too expensive relative to other alternatives, particularly coal fired power plants. It is this issue of the cost of nuclear power that is the central topic of this paper.

The basic economic advantage of nuclear power has always been low fuel costs relative to fossil fuel units. The economic viability of nuclear power is currently under attack on the ground that other costs of nuclear power are overwhelming this fuel cost advantage. Specifically, it is argued that: 
1. Escalation of capital costs for nuclear units will, if it continues, more than offset the inherent fuel cost advantages of nuclear power.

2. The operating performance of the new large (1000 MWe and over) nuclear units has been poor, resulting in low plant availability factors and high maintenance costs. Coupled with high capital costs per kwh of electricity generated, it is argued that the result is a total cost per kwh greater for nuclear units than for coal units in much of the country.

The discussion of this paper is concerned with escalation of nuclear capital costs, which is well documented in the data available. The argument concerning the operating performance of large nuclear units is still a matter of considerable controversy, in large part because only two or three years of operating experience are available for the typical large unit. In any case, however the argument concerning operating performance is resolved, escalation of capital costs remains a central issue so far as the economics of the nuclear industry is concerned.

Our approach in this paper is historical, summarizing data on the course of development of the nuclear power industry, and examining some of the leading explanations for that course of development. Based on previous unsuccessful attempts by the AEC and others to predict the future course of the industry, it might be well to point out that we do not attempt any such projections 
here. Instead, we feel that there is a contribution to be made simply by recounting what has happened and attempting to understand that.

We examine in detail the two basic explanations that have been offered for capital cost escalation in nuclear power; namely, first, the argument that cost increases are related to the activities of intervenors in the nuclear licensing process; and, second, the argument that cost increases reflect bottleneck problems in construction, equipment supplying industries, and in the licensing process. As will be developed later, capital cost increases in the nuclear industry far exceed those that would have resulted simply from inflation of the general price level, or even inflation of the construction industry price level. Hence an explanation of the differential rate of escalation of nuclear costs must ultimately rest on characteristics specific to the nuclear industry.

Our general conclusions are these: in the early years of commercial development of the nuclear power industry (1966-1970), the bottleneck hypothesis accounts for most of the cost increases that occurred; but, since 1970, while bottleneck effects are still present, the procedural and substantive effects of intervention in the licensing processes have dominated the cost picture. We develop these conclusions in the course of a narrative description of the economic history of the industry, rather than attempting an explicit statistical treatment aimed at identifying the quantitative importance of these two underlying hypotheses. Data problems relating to 
sma11 sample size, site specific characteristics of nuclear units, serial and auto correlation, and other related issues argue against the reliability of sophisticated statistical models in the analysis of the cost escalation problem.

The period from the early 1960s to the present has been one of dramatic changes in the technology and costs of power generation, not only in the nuclear industry, but also in coal, oil and natural gas. Moreover, it has been a period during which the federal government has played an increasingly important role in influencing investment decisions by electric utilities. Thus in our analysis of the development of the nuclear power industry, we place special emphasis on the information available to decision makers at the time that decisions were made and how that information was used, rather than judgements as to whether the decisions make sense from the point of view of informed hindsight. With one or two notable exceptions, a rather consistent picture of the period can be constructed using the usual model of the economist, namely that decision makers, whether utilities or reactor manufacturers, tended to make profit maximizing choices based on the best data available, and that the market for nuclear units was relatively responsive to changes in information.

To develop these points, we begin with a brief description of the pattern of growth in nuclear generating capacity and changes in nuclear costs. Then we turn to a detailed description of the economic decisions which created those patterns. 
BACKGROUND: THE GROWTH OF NUCLEAR POWER

Table 1 summarizes the statistics on the growth of the nuclear power industry over the period 1955 to 1976 . The term NSSS refers to "nuclear steam supply system," the heart of the nuclear unit. As indicated by the final four columns, units ordered up through 1961 were mainly small prototype reactors (capacity of less than 100 MWe), but beginning in 1962 , commercial size reactors dominate the picture. The history of the industry has been characterized by a rapid growth in unit size, the typical unit under order being in the 600 MWe range in the mid-1960s in contrast to a typical size of $1000 \mathrm{MWe}$ and more in the mid-1970s. Except for a handful of large coal units, only nuclear plants are built in the 1000 MWe and over range, even today.

Construction and operation of a nuclear plant requires licenses from the AEC (now NRC). The licensing-construction process involves four basic stages: applying for and receiving a construction permit; building under a construction permit until construction is far enough along so that the design is finalized, at which time an operating license application is filed; applying for and receiving an operating license; testing under the operating license until approval is received for operating the plant commercially, under full power. The second pair of columns in Table 1 1ists the number and capacity of units attaining commercial status for each year in the 1955-1976 time span. Finally, the last two colums of the table list the installed capacity of the nuclear power industry, figures that reflect both the commissioning of new units and the 
TABLE 1

GROWTH OF NUCLEAR POWER

NSSS Orders

Net

Year

1955

1956

1957

1958

1959

1960

1961

1962

1963

1964

1965

1966

1967

1968

1969

1970

1971

1972

1973

1974

1975

1976

Orders

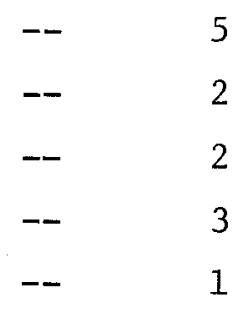

1
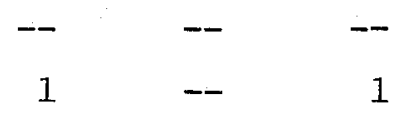

$\begin{array}{lll}7 & -- & 7\end{array}$

21

16

$\begin{array}{rrr}16 & - & 16 \\ 8 & -- & 8\end{array}$

$\begin{array}{lll}15 & 1 & 14\end{array}$

$21 \quad 1 \quad 20$

37

5

32

$33 \quad 11 \quad 22$

$4 \quad 6 \quad-2$

Units Attaining

Com'1 Status
Installed

Capacity

No. MWe $\quad$ No. $\quad$ MWe
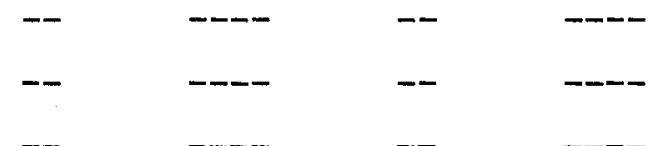

1

$$
-
$$

200

1

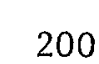

1

175

2

375

1

265

3

640

2

140

780

5

830

3

50

8

902

1

72

9

992

1

90

10

1004

1

40

9

2007

1025

10

3267

143

1260

12

5036

1796

15

8678

6

3615

21

14351

$\begin{array}{llll}38 & 5 & 33 & 8\end{array}$

8

5673

29

18864

7

4513

36

28351

11

9527

46

37188

10

8837

56

39815

Source: Status of Central Station Nuclear Power Reactor, Significant Milestones, ERDA-30, July 1976, and Electrical Wor1d, 1965-1977. 
decomissioning (or shutdowns) of older units.

There is a pronounced cyclic character to orders for NSSS's, a feature common to all capital goods industries. This leaves it at least open to question whether the recent falling off of orders is simply a hiatus before a new cyclical revival, or whether the decline signals a permanent bottoming out of orders.

The rate of growth in installed capacity has been impressive, with capacity doubling approximately every two years over the 1966-1976 period. Moreover, it is clear that whatever is the long term economic picture for nuclear power, units already in the pipeline will result in large increases in installed capacity for a number of years to come. As of the end of 1976, there were 59 nuclear units operating to produce power in the United States; and as of July 1976, there were 134 units (with average size perhaps 50 percent larger than the average of installed units) in the construction-1icensing pipeline.

Table 2 identifies the number of units at various stages of the licensing-construction process as of July 1976, and during earlier periods. Units already in the pipeline would increase nuclear generating capacity over its present level by something on the order of 300 percent, over the next five to ten years. About half of those units are still awaiting construction permits, and others are in early stages of construction. Units in the early stages of licensing and construction can be, and have been, canceled or deferred. Consequently, the backlog is not an irreversible commitment to nuclear power, although construction of many units is so far advanced that outright cancellation is unlikely. Appendix $\mathrm{C}$ to this paper provides 
TABLE 2

BACKLOGS IN THE LICENSING-CONSTRUCTION PROCESS (UNITS IN EACH PROCESS AT END OF YEAR)

\begin{tabular}{|c|c|c|c|c|c|}
\hline Year & $\underline{\mathrm{CP}}$ & $\begin{array}{c}\text { Primary } \\
\text { Construction } \\
\end{array}$ & $\underline{\mathrm{OL}}$ & $\begin{array}{l}\text { Testing For } \\
\text { Commercia1 }\end{array}$ & Total \\
\hline 1955 & 2 & -- & -- & -- & 2 \\
\hline 1956 & 1 & 3 & -- & -- & 4 \\
\hline 1957 & - & 4 & -- & -- & 4 \\
\hline 1958 & 1 & 3 & 2 & -- & 6 \\
\hline 1959 & 6 & 3 & -- & 2 & 11 \\
\hline 1960 & 1 & 8 & 2 & -- & 11 \\
\hline 1961 & 1 & 3 & 7 & -- & 11 \\
\hline 1962 & 1 & 1 & 3 & 6 & 11 \\
\hline 1963 & 2 & 2 & 2 & 5 & 11 \\
\hline 1964 & 1 & 4 & 1 & 4 & 10 \\
\hline 1965 & 4 & 3 & 3 & 2 & 12 \\
\hline 1966 & 15 & 7 & 3 & 2 & 27 \\
\hline 1967 & 26 & 17 & 4 & 4 & 51 \\
\hline 1968 & 15 & 31 & 13 & 1 & 60 \\
\hline 1969 & 19 & 30 & 17 & 3 & 69 \\
\hline 1970 & 27 & 26 & 26 & 6 & 85 \\
\hline 1971 & 35 & 14 & 37 & 3 & 89 \\
\hline 1972 & 33 & 18 & 36 & 1 & 88 \\
\hline 1973 & 47 & 24 & 32 & 6 & 109 \\
\hline 1974 & 67 & 40 & 25 & 9 & 141 \\
\hline 1975 & 65 & 48 & 25 & 2 & 140 \\
\hline 1976 & 60 & 48 & 24 & 2 & 134 \\
\hline
\end{tabular}

Source: Status of Central Station Nuclear Power Reactors, Significant Milestones, ERDA-30, July 1976. 
details on orders, cancellations and delays in the licensing-construction process.

The increase in the reported cost of nuclear power plants has been as dramatic as the growth of the nuclear industry. Units coming on line in the late 1960s and early 1970 s had reported costs in the range of $\$ 150$ per kilowatt; by 1976 reported costs for units coming on line had increased to $\$ 560$ per kilowatt. Thus, capital costs $(\$ / k w)$ of nuclear units have increased by approximately 300 percent over the 1968-1976 period, while the general price index has increased by "only" 67 percent. ${ }^{1}$ However, it is important to emphasize that "reported" costs in the early years (1968-1971) almost certainly understated the true costs for the units coming on line during that period, so that cost comparisons involving these early years are next to worthless. But even when the early years are ignored, the rate of increase in capital costs for nuclear units far outstrips the rate of general inflation. Table 3 summarizes data on capital costs using both FPC and AEC/ERDA figures (see Appendix A for details). The period 1968-1971 is dominated by the so-called "turnkey" plants, where reported costs (by utilities) are generally agreed to be far less than costs incurred (by reactor manufacturers) in the construction of these units. To identify the factors responsible for increasing costs and to explain how the nuclear power industry continued to grow for a time in the face of substantial cost increases, a more detailed account of the economic history of nuclear power is required. We begin with a discussion 
TABLE 3

REPORTED CAPITAL COSTS OF

NEW NUCLEAR UNITS

1968-1976

FPC AND AEC/ERDA

\section{Capital Cost $\$ / \mathrm{kw}$}

$\underline{\text { Year }}$

FPC

AEC/ERDA

Avg. Range

Avg. Range

1968

$164 \quad 153-180$

$192 \quad 165-228$

1969

$215 \quad 163-262$

$205 \quad 157-247$

1970

$138 \quad 114-161$

$127 \quad 116-155$

1971

$146 \quad 101-185$

$139 \quad 109-169$

1972

$188 \quad 12 I-353$

$217 \quad 122-333$

1973

$251 \quad 161-393$

$240 \quad 184-383$

1974

$362 \quad 258-546$

$329 \quad 184-504$

1975

n.a.

$428 \quad 251-518$

1976

n.a.

$560 \quad 415-692$

Sources: FPC, Steam Electric Plant Construction Cost and Annual Production Expenses, 1968-1974; AEC/ERDA, Central Station Nuclear Plants, selected issues 1968-1977 
of the turnkey period, during which construction of the first large (over $400 \mathrm{MW}$ ) commercial reactors commenced.

THE TURNKEY ERA, 1963-1966 2

The Atomic Energy Act of 1954 provided a mandate for the $\mathrm{AEC}$ to develop and regulate a commercial nuclear power industry. The first stage in this effort was a program of research and development activities designed to identify commercially viable reactor types. This program, designated as the Power Reactor Demonstration Program (PRDP), involved partial AEC financing (in collaboration with utilities) of a number of small reactors between 1955 and 1961. By 1962, the LWR (1ight water reactor) had been established as the most immediately promising of the reactor types, with the breeder reactor and gas cooled reactor still at a development stage.

The problem with the LWR was that capital costs for the small units that had been constructed under PRDP were too high to provide competitive generating costs relative to fossil fuel power plants. Commercialization of the LWR required a move to larger capacity units, say in the 200-400 MWe and over range, where capital costs per kw were expected to show a sizeable drop. But utilities were not willing to undertake the risks of financing such plants, and when the AEC showed no inclination to subsidize plants of this size, orders for reactors simply ceased. At this point, in 1962, the Joint Committee for Atomic Energy stepped into the picture by specifically earmarking $\$ 20$ million of previously 
appropriated AEC funds for design and research and development assistance to subsidize construction of commercial size LWRs. Two reactors were financed in part by the AEC under this new authorization, the last two LWRs to receive government assistance -Connecticut Yankee (NSSS order in December 1962) and San Onofre 1 (NSSS order in January 1963). Both of these units were built by Westinghouse, and both were built under so-called "turnkey" contracts. Turnkey contracts were contracts under which the builder of the reactor took on all of the responsibility for designing and building the unit, including any actions required to meet regulatory guidelines. After the plant had passed through the licensing process, including testing to attain commercial status, the plant was then turned over to the utility for operation. The typical turnkey contract also provided a financial guarantee in the form of a fixed price for the unit, this price to cover all of the costs of construction and licensing, exclusive of interest during construction.

San Onofre and Connecticut Yankee were contracted for at prices to the utility (after deducting the AEC subsidy) of around $\$ 180 / \mathrm{kw}$. This still left a competitive advantage to coal power plants, with capital costs in the $\$ 110-\$ 160 / \mathrm{kw}$ range. Then, in December 1963, came the dramatic announcement that General Electric had agreed to build the Oyster Creek unit for Jersey Central at a turnkey price of $\$ 132 / \mathrm{kw}$, with no AEC subsidy. Added to the known fuel cost advantages of nuclear units, this capital cost was so low that nuclear power was actually cheaper than coal power at Oyster Creek, the first instance of a nuclear unit being built on the basis 
of economic advantages alone.

For the next two and one-half years, General Electric, Westinghouse and several of the small reactor manufacturers (including General Atomics and Allis-Chalmers) offered turnkey contracts at fixed prices at or near the Oyster Creek level. In a11, 13 plants were contracted for on a turnkey basis between December 1962 and mid-1966. 3 Then, in June 1966, GE announced that it would no longer offer complete nuclear power plants on a firm-price (turnkey) basis in the United States (turnkey contracts are still available for foreign orders). As a practical matter, Westinghouse also pulled out of the turnkey business at about the same time, although a formal announcement to this effect was not made until 1971. 4

The initial response of the utility industry to the Oyster Creek announcement was one of cautious skepticism; only two nuclear units were announced in 1964 and six in 1965 . But in 1966, a flood of 23 announcements were made, most after June and most on a nonturnkey basis. This continued into 1967, with 27 more announcements. Whatever else can be said about the turnkey era, it is a fact that for the nuclear power industry it represented a transition from a period of being a heavily subsidized step-child of the AEC to a period of being a vigorous competitor with fossil fuels for base load power plants.

From all reports, the turnkey contracts signed by General Electric and Westinghouse turned out to be first class financial disasters for the two companies. Mooz (1966) cites correspondence 
with executives of the two companies that indicate combined losses in the range of $\$ 1$ billion, and there is corroboration for this estimate from the CONCEPT cost model developed by United Engineers and discussed in WASH-1345. Specifically, the comparisons between reported costs (by the utilities) of turnkey units and the WASH-1345 estimated costs (to the contractor) are as follows.

Turnkey Units $\quad \begin{array}{ccc}\begin{array}{c}\text { Reported } \\ \text { Cost }\end{array} & \begin{array}{c}\text { WASH-1345 } \\ \text { Estimated Cost }\end{array} & \begin{array}{c}\text { Estimated } \\ \text { Loss }\end{array} \\ \text { (Millions of Dollars) }\end{array}$

General Electric

\begin{tabular}{|c|c|c|c|}
\hline Oyster Creek & $\$ 91$ & $\$ 170$ & $\$ 79$ \\
\hline Dresden 2,3 & 230 & 413 & 183 \\
\hline Millstone & 97 & 182 & 85 \\
\hline Quad Cities 1, 2 & 250 & 448 & 198 \\
\hline Monticello & 105 & 168 & 63 \\
\hline Totals & $\$ 773$ & $\$ 1381$ & $\$ 608$ \\
\hline
\end{tabular}

Westinghouse

\begin{tabular}{lrrr} 
San Onofre & $\$ 97$ & $\$ 131$ & $\$ 34$ \\
Ginna & 83 & 161 & 78 \\
Robinson & 78 & 179 & 101 \\
Point Beach 1, 2 & 128 & 329 & 201 \\
Connecticut Yankee & $\underline{92}$ & $\underline{149}$ & $\underline{57}$ \\
\multicolumn{1}{|}{ Totals } & $\underline{\$ 478}$ & $\underline{\$ 949}$ & $\underline{\$ 471}$ \\
\multicolumn{1}{c}{ Combined Totals } & $\underline{\$ 1251}$ & $\underline{\$ 2330}$ & $\underline{\$ 1079}$
\end{tabular}

Source: Power Plant Capital Costs, WASH-1345, AEC, October 1974. 
The estimated losses presented above should be viewed as, at best, educated guesses, in part because estimates of capital costs prepared by United Engineers for the AEC have not proved to be particularly accurate in the past. ${ }^{5}$

Whatever the exact figures, there seems little doubt that General Electric and Westinghouse lost substantial amounts of money on the turnkey contracts of the 1963-1966 period. And, because the turnkey era was pivotal in the history of the nuclear power industry, it is important to try to understand the motivations of reactor manufacturers and utilities at that time, and how market forces in the nuclear power industry might have operated.

One version of the history of the turnkey era goes something like this. 6 General Electric negotiated the Oyster Creek contract at a time when the nuclear power industry was at a standstil. General Electric engineers expected to take a loss on Oyster Creek, but acted in the expectation that if two other such units could be built, the learning curve would lower construction costs enough so that General Electric could at least break even on three units. Westinghouse was forced to offer contracts at or near the Oyster Creek price by the competitive pressures applied by General Electric. But as construction proceeded, it became clear both to General Electric and Westinghouse that costs would far exceed original estimates, at which point turnkey contracts were withdrawn from the market. However, the effect of the turnkey period on utilities was to create expectations that nonturnkey units would come in at costs near the turnkey prices, so that orders continued to come 
in for reactors even after the turnkey option was phased out. Whether intended or not, the turnkey era produced the kinds of results associated with a "loss leader" strategy, in terms of expanding demand for nuclear units. As it turned out, the nonturnkey units came on. line six to eight years later at costs two to three times higher than turnkey prices, so that both the reactor manufacturers (on turnkey contracts) and the utilities (on nonturnkey contracts) suffered losses deriving from their overly optimistic expectations as to costs.

The main problem with this story of the turnkey era is clear evidence that cost problems with the turnkey units stemmed largely from the post-turnkey period. The reasons cited for cost overruns by Westinghouse in Mooz' study were: (1) a dramatic change in labor costs (annual rate of increase of 30 percent from 1967 on versus a rate of increase of about 5 percent prior to 1967 ); (2) birth of the environmental movement; (3) increases in licensing costs; (4) decreases in labor productivity. A11 of these factors came to the fore only after 1966, that is, only after turnkey contracts had already been withdrawn. And there is no evidence of special sources of information available to General Electric and Westinghouse concerning these general economic trends that were not also available to utilities planning nuclear units .

An alternative to the "Ioss leader" argument as an explanation for the growth in nuclear orders following the turnkey era is as follows. There are certain advantages to utilities from 
nuclear power that make it a desirable investment even if generating costs are slightly higher for nuclear relative to fossil fuel plants. First, there is a spreading the risk argument: given that a utility is already using coal, oil and/or natural gas units, adding a nuclear unit reduces the vulnerability of a utility to fossil fuel price increases or lack of availability. Second, nuclear is a high capital cost-low operating cost power source. Adding nuclear units increases the rate base of the regulated utility more than would be the case with alternative power sources and hence increases allowed profits for any given level of output. Third, at the time, nuclear power was regarded as a "clean" fuel, and hence would be less subject to problems of siting and pollution control.

These inherent advantages of nuclear power were offset prior to the turnkey era by uncertainties as to capital costs and uncertainties as to the technical feasibility of large nuclear units. The reactor manufacturers had strong incentives to prove out the technology of large reactors in the mid-1960s. They did this, in effect, by engaging in privately financed demonstration projects, subsidizing the building of the turnkey plants. As construction progress was reported on San Onofre and Connecticut Yankee, the concerns of the utilities as to technological risks diminished. Moreover, by the end of the turnkey era, capital costs of coal plants were increasing at the rate of 15 percent or more per year, and there was a general expectation that coal prices would increase in the future, an expectation that was realized in the wake of the mine safety legislation of 1969. Fina11y, reported costs on the 
turnkey units under construction (and on nonturnkey units such as Nine Mile Point) were favorable. The point is that there were a number of factors, over and above estimated capital costs of nuclear units, that encouraged utility investments in nuclear units, even after the turnkey era had ended.

As noted earlier, capital costs to electric utilities for the nonturnkey units contracted for in the immediate post-turnkey era were badly underestimated. But even in the face of those underestimates, it can be argued that, from hindsight, utilities going nuclear at that time might well have made the correct decision. Developments in alternative fuels, especially coal, acted in part to offset the underestimates of nuclear capital costs.

It seems to us that the turnkey era can only be understood in terms of the distinction between technological risks and cost risks. While the reactor manufacturers had incentives to establish the technological feasibility of large nuclear units, since they could capture the rents from a successful demonstration program, the utilities appear to be in a better position to bear cost risks. Turnkey contracts are rare in the history of United States utilities for that very reason. As a permanent fixture of the contracting process, the price quoted for a turnkey contract would have to incorporate an actuarially sound insurance premium against cost increases. The withdrawal of turnkey contracts once utilities were convinced of the technological feasibility of large nuclear units can be interpreted as a return to the historical practices of the industry with the utility bearing cost risks, because self-insurance 
against such risks was preferable to the "contingency" premium that would have been built into future turnkey contracts.

There are several reasons for this. In the first place, the utilities are regulated monopolists, able to pass through cost increases to customers through rate increases, while the reactor manufacturers were operating in a competitive environment, competing with fossil fuel units and less able to absorb such cost increases. Moreover, there are moral hazard problems in turnkey-type contracts. The utility is interested in obtaining the lowest total cost of electricity possible for its base load plants, but a turnkey contract only provides a guarantee as to the capital cost of the plant. To the extent that there is the possibility of substitution between low capital cost components and 1ow operating cost components, the incentives for the contracting firm under a turnkey contract are to opt for the low capital cost component. Thus there might well be sound economic reasons for a utility to prefer a nonturnkey contract to a turnkey contract, even if the capital cost of the nonturnkey unit is greater than that of the turnkey unit. We can of course on $1 y$ speculate on the forces that were at work during the turnkey era. One thing is clear, however; by the end of the era, the nuclear industry had established itself as a major force in the future development of electric power in the United States.

THE COMMERCIAL SUCCESS OF NUCLEAR POWER 1966-1970 As the turnkey era ended, commercialization of nuclear power 
was an accomplished fact. In 1966 twenty plants were ordered, six on turnkey contracts. The remaining reactors, and almost all reactors ordered after 1966, were built by utilities under normal financial arrangements involving contracting with architect-engineers. During 1967, thirty reactors were ordered, but only one was on a turnkey basis. In 1968 and 1969 orders dropped off to fourteen and then seven reactors; by 1970 orders were back up to fourteen.

\section{Nuclear Costs in Contemporary Perspective}

Construction of the reactors ordered in 1966 and 1967 on a nonturnkey basis did not begin until at least twelve months after the orders were announced, because of time required for granting of various licenses. Consequently the initial surge of decisions to build nuclear plants occurred with little experience with construction of large nuclear reactors under normal utility contracting procedures. Nevertheless a mood of general optimism about total nuclear costs -both capital and operating - appears to have pervaded this industry. Electrical World (November 7, 1966) quoted Dr. Alvin Weinberg as saying that reactors ordered during 1966 would produce electricity at a cost of 25 percent less than that of coa1, and in mid-1967, TVA Board member Frank Smith described nuclear power as having a clear but somewhat smaller advantage in the TVA area.

There were, however, some warnings that turnkey quotations were unreliable bases for projections of nuclear costs. Genera1 Electric's annual report issued in 1967 stated that "earlier commitments made to win customer acceptance of the new [nuclear] 
technology continue to affect earnings." Stephen F. Dunn, president of the National Coal Association, said that General Electric's annual report illustrated that coal was a more competitive fuel than turnkey prices implied (Electrical World, April 10, 1967).

The trend in actual and estimated nuclear capital costs is apparent from Figure 1. Three time series are plotted in that figure:

1. The average estimated capital costs of all plants ordered in the previous year, as reported by utilities to AEC/ERDA.

2. The average of updated capital cost estimates for all plants still under construction during the previous year (and ordered in years prior to the previous year).

3. The average actual capital cost of all plants completed in the previous year, using AEC/ERDA data.

The same data are displayed in a somewhat different format in Table 4. Complete cost data on a plant by plant basis are provided in Appendix Table A-2. During 1966 and 1967, estimates of nuclear costs appear to have been based on the price quotations for turnkey plants. During 1967 updated estimates of the cost of nonturnkey plants under construction became available. They indicated that actual costs would exceed initial estimates, but not by a large margin. 
FIGURE 1

ESTIMATED AND ACTUAL CAPITAL COSTS

1966-1976

(Data missing on estimated costs for 1974)

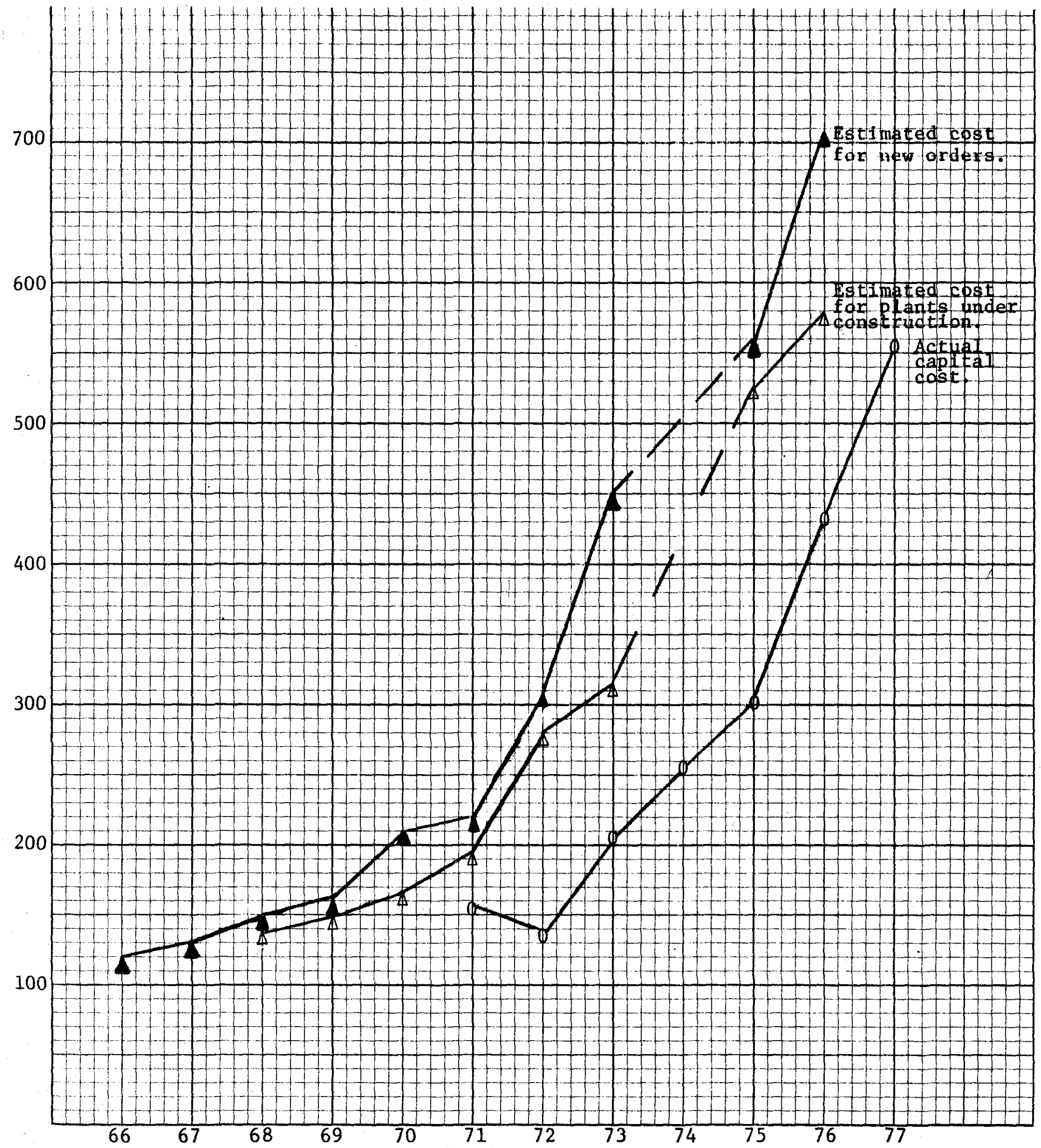


Table 4

AVERAGE ESTIMATED FINAL COST, \$/kw, AT SELECTED POINTS IN TIME, FOR

NUCLEAR UNITS UNDER CONSTRUCTION, 1965-1975

\begin{tabular}{|c|c|c|c|c|c|c|c|c|c|}
\hline NSSS & & & & Estim & Fina1 & $\$ / \mathrm{kw}$ & as of: & & \\
\hline Order Date & $1 / 67$ & $1 / 68$ & $1 \longdiv { 6 9 }$ & $3 / 70$ & $1 / 71$ & $1 / 72$ & $1 / 73$ & $1 / 75$ & $4 / 76$ \\
\hline 1965-Turnkey & 137 & 133 & 131 & 129 & 143 & 155 & 226 & - & - \\
\hline Other & 123 & 138 & 148 & 170 & 215 & 257 & 279 & 694 & - \\
\hline 1966-Turnkey & 126 & 125 & 126 & 117 & 131 & 129 & 157 & - & - \\
\hline Other & 122 & 129 & 141 & 160 & 188 & 213 & 277 & 328 & 429 \\
\hline 1967 & - & 148 & 148 & 171 & 194 & 237 & 319 & 448 & 539 \\
\hline 1968 & - & - & 156 & 193 & 206 & 252 & 359 & 460 & 578 \\
\hline 1969 & - & - & - & 208 & 228 & 328 & 375 & 571 & 701 \\
\hline 1970 & - & - & - & - & 217 & 248 & 301 & 402 & 501 \\
\hline 1971 & - & - & - & - & - & 301 & 370 & 521 & 591 \\
\hline 1972 & - & - & - & - & - & - & 420 & 541 & 722 \\
\hline 1973 & - & - & - & - & - & - & - & 583 & 678 \\
\hline 1974 & - & - & - & - & - & - & - & 549 & 690 \\
\hline 1975 & - & - & - & - & - & - & - & - & 694 \\
\hline
\end{tabular}

Source: Central Station Nuclear Plants, AEC and ERDA, selected issues, 1967-1976 
Estimates of the cost of newly ordered plants did increase from year to year between 1968 and 1971, rising from about $\$ 150$ per kilowatt in 1968 to $\$ 220$ per kilowatt in 1971 . They rose more rapidly than interim estimates of the cost of plants under construction, but perhaps no more than sufficiently to incorporate the additional inflation that would affect plants with later completion dates.

\section{Licensing Delays}

Between 1967 and 1970, problems in licensing and constructing nuclear plants began to surface. With a total of 50 new commitments to deal with during 1966 and 1967, the AEC's capacity to process applications showed signs of strain.

By the fall of 1967 licensing delays were apparent throughout the industry and, by the end of 1967,26 plants were caught in the construction permit process alone. Table 5 reveals that the time required to obtain a construction permit for a reactor ordered in 1968 was 14 months longer, on average, than it had been for a reactor ordered in 1966. Between 1966 and 1970, the situation worsened as the time required to obtain a construction permit (CP) increased by another 15 months. The actual distribution of time to obtain CPs is detailed in Table 6 .

During the 1966-1970 period, intervenors such as environmental groups, states, and municipalities, entered the licensing process. There were a few well publicized cases in which the activities of intervenors resulted in lengthening of the licensing process. 


\section{CP Application}

$\begin{array}{llr}7 / 66 & \text { CP application } & \\ 7 / 67 & \text { CP issuance } & 12 \text { months } \\ 7 / 69 & \text { OL application } & 24 \text { months } \\ 5 / 73 & \text { OL issuance } & 46 \text { months } \\ 9 / 73 & \text { commercial status } & \frac{4 \text { months }}{86 \text { months }}\end{array}$

(Average time, CP application to commercial, 7 years, 2 months.)

\section{CP App1ication}

Change from 1966

(Months)

$\begin{array}{lllr}7 / 68 & \text { CP application } & \\ 9 / 70 & \text { CP issuance } & 26 \text { months } & +14 \\ 3 / 73 & \text { OL application } & 30 \text { months } \\ ? / 77 & \text { OL issuance } & \\ ? / 77 & \text { commercial status } & \\ & & \\ \text { (Average time, CP app1ication to commercial, over } 8 \text { years.) }\end{array}$

1970 CP Application

Change From

$1966 \quad 1968$

(Months)

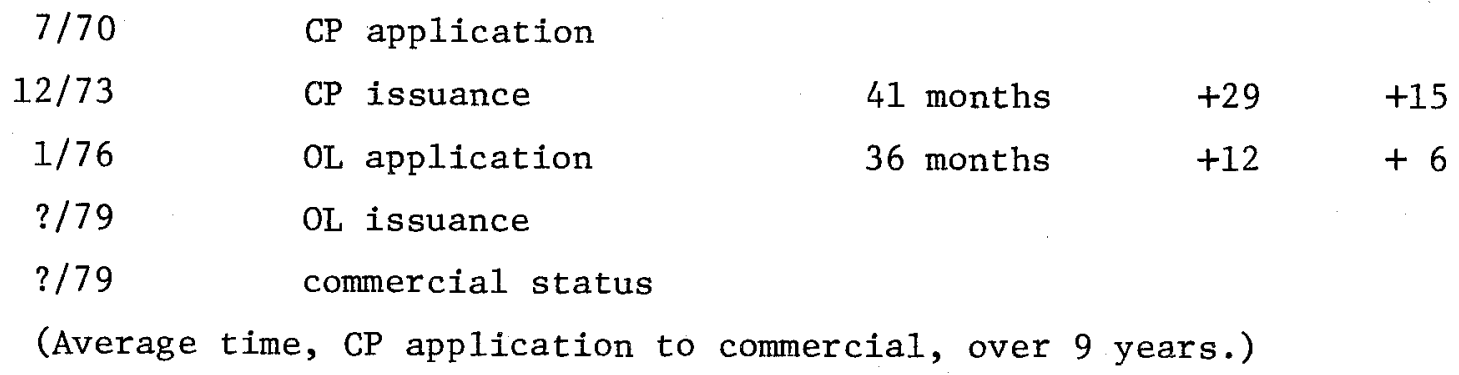


TABLE 6

REGULATORY TIME LAGS - NUCLEAR LICENSING

I. Construction Permit Phase

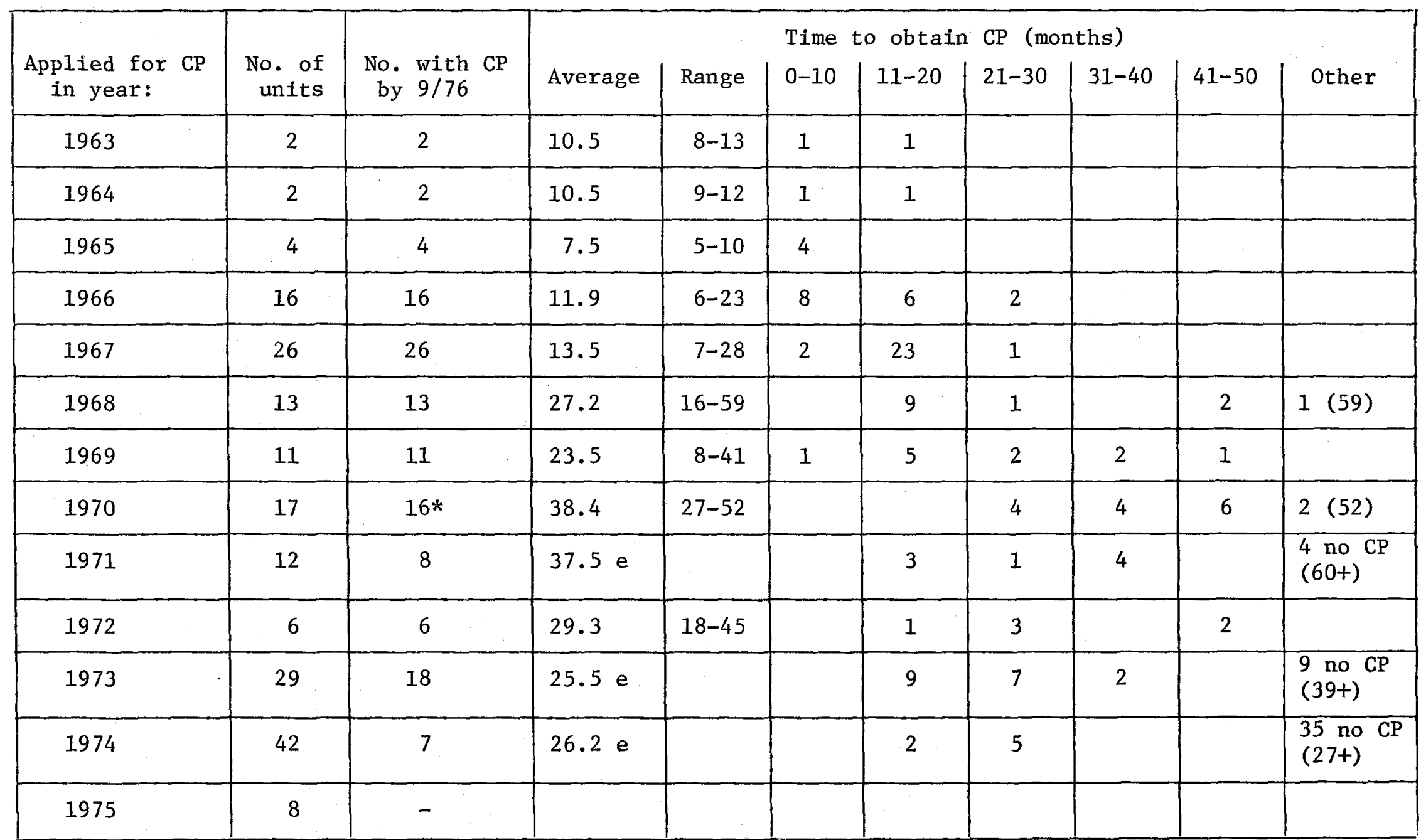

* One cancellation.

e refers to the minimum possible average for that year; i.e., by assuming that plants not obtaining CP by $9 / 76$ actually obtain $\mathrm{CP}$ in $10 / 76$. 
TABLE 6

REGULATORY TIME LAGS - NUCLEAR LICENSING

II. Primary Construction Phase - CP to Application for Operating License

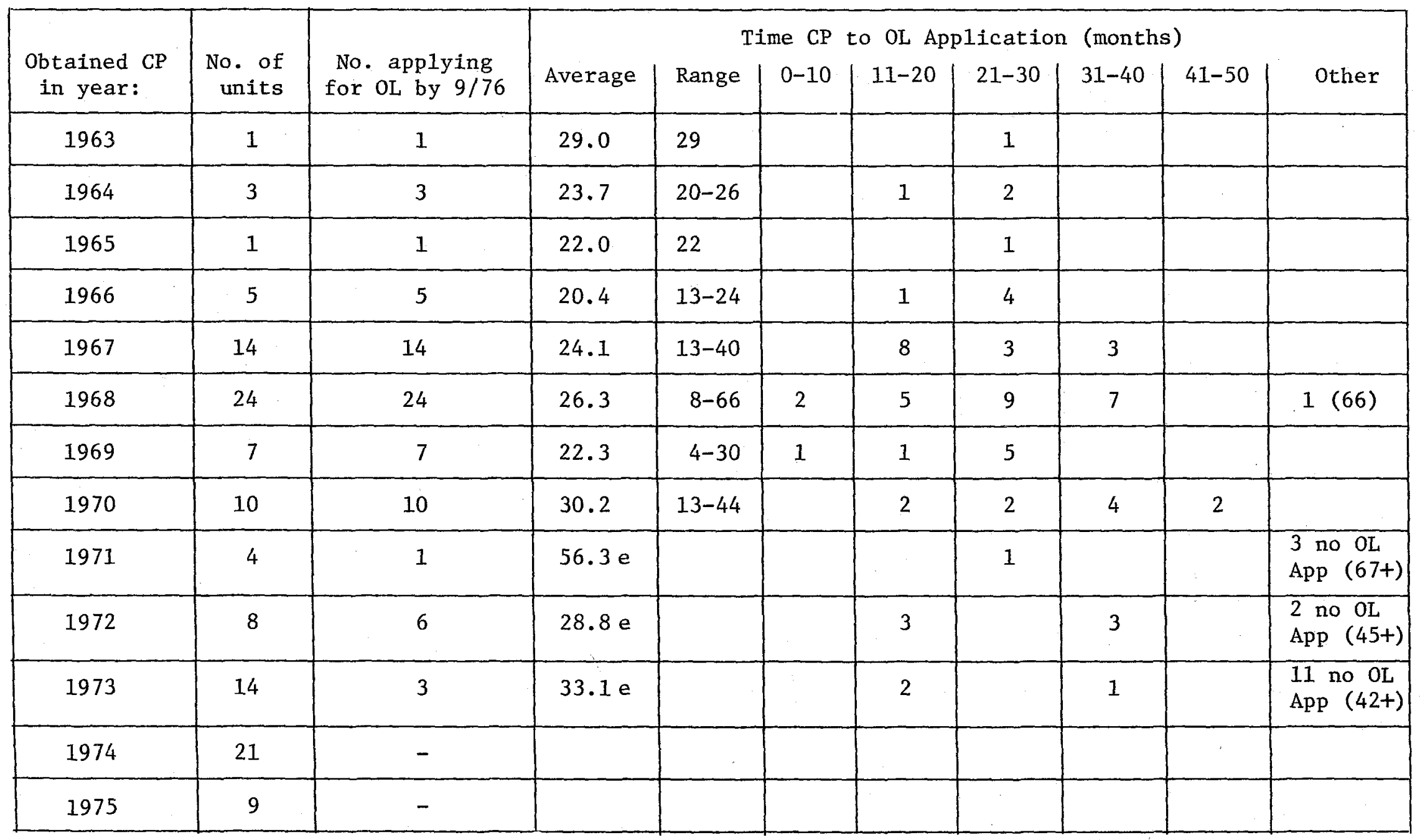

e refers to the minimum possible average for that year; i.e., by assuming that plants not applying for oL by $9 / 76$ actually apply in $10 / 76$. 
III. Operating License Phase

\begin{tabular}{|c|c|c|c|c|c|c|c|c|c|c|}
\hline $\begin{array}{l}\text { Applied for } \\
\text { OL in year: }\end{array}$ & $\begin{array}{l}\text { No. of } \\
\text { units }\end{array}$ & $\begin{array}{l}\text { No. with oL } \\
\text { by } 9 / 76\end{array}$ & Average & Range & $0-10$ & $\begin{array}{l}\text { me to } \\
11-20\end{array}$ & $\begin{array}{l}\text { tain Ol } \\
21-30\end{array}$ & $\begin{array}{l}\text { (month } \\
31-40\end{array}$ & $41-50$ & Other \\
\hline 1963 & - & - & - & - & & & & & & \\
\hline 1964 & 1 & 1 & 23.0 & 23 & & & 1 & & & \\
\hline 1965 & 2 & 2 & 19.5 & $16-23$ & & 1 & 1 & & & \\
\hline 1966 & 1 & 1 & 11.0 & 11 & & 1 & & & & \\
\hline 1967 & 4 & 4 & 29.0 & $25-38$ & & & 3 & 1 & & \\
\hline 1968 & 8 & 8 & 21.1 & $20-42$ & & 3 & 1 & 3 & 1 & \\
\hline 1969 & 10 & 10 & 41.5 & $18-61$ & & 1 & & 3 & 4 & $\begin{array}{ll}1 & (52) \\
1 & (61)\end{array}$ \\
\hline 1970 & 15 & 15 & 40.1 & $24-69$ & & 1 & 4 & 4 & 4 & $\begin{array}{ll}1 & (60) \\
1 & (69)\end{array}$ \\
\hline 1971 & 15 & 12 & $45.5 \mathrm{e}$ & & & & 2 & 5 & 3 & $\begin{array}{lll}1 & (60) & 3 \text { no OL } \\
1 & (67) & (65+)\end{array}$ \\
\hline 1972 & 4 & 3 & $32.3 \mathrm{e}$ & & & & 2 & 1 & & $\begin{array}{l}1 \text { no OL } \\
(47+)\end{array}$ \\
\hline 1973 & 5 & 2 & - & & & & & 2 & & \\
\hline 1974 & 5 & - & - & & & & & & & \\
\hline 1975 & 3 & - & - & & & & & & & \\
\hline
\end{tabular}

e refers to the minimum possible average for that year; i.e., by assuming that plants not obtaining ol by $9 / 76$ actually obtain ot in $10 / 76$. 
IV. Operating License to Commercial Operation

\begin{tabular}{|c|c|c|c|c|c|c|c|c|c|c|}
\hline $\begin{array}{l}\text { Obtained } \mathrm{OL} \\
\text { in year: }\end{array}$ & $\begin{array}{l}\text { No. of } \\
\text { units }\end{array}$ & $\begin{array}{l}\text { No. commercial } \\
\text { by } 9 / 76\end{array}$ & Average & Range & $\begin{array}{l}m e-c \\
0-10\end{array}$ & $\begin{array}{l}\text { to con } \\
11-20\end{array}$ & $\begin{array}{r}\text { ercial } \\
21-30\end{array}$ & $\begin{array}{c}\text { peratio } \\
31-40\end{array}$ & $\begin{array}{l}\text { (month } \\
41-50\end{array}$ & Other \\
\hline 1963 & 1 & 1 & 2.0 & 2.0 & 1 & & & & & \\
\hline 1964 & 2 & 2 & 0 & 0 & 2 & & & & & \\
\hline 1965 & - & - & - & - & - & & & & & \\
\hline 1966 & 1 & 1 & 17.0 & 17 & & 1 & & & & \\
\hline 1967 & 3 & 3 & 19.7 & $7-42$ & 2 & & & & 1 & \\
\hline 1968 & - & - & - & - & & & & & & \\
\hline 1969 & 4 & 4 & 7.5 & $4-10$ & 4 & & & & & \\
\hline 1970 & 3 & 3 & 5.7 & $4-8$ & 3 & & & & & \\
\hline 1971 & 6 & 5 & $20.2 \mathrm{e}$ & & 2 & 2 & 1 & & & $\begin{array}{l}1 \text { no } \operatorname{com}^{\prime} 1 \\
(58+)\end{array}$ \\
\hline 1972 & 4 & 4 & 6.0 & $0-9$ & 4 & & & & & \\
\hline 1973 & 12 & 12 & 2.3 & $0-13$ & 11 & 1 & & & & \\
\hline 1974 & 15 & 14 & $2.3 \mathrm{e}$ & & 14 & & & & & $\begin{array}{l}1 \text { no } \operatorname{com}^{\prime} 1 \\
(29+)\end{array}$ \\
\hline 1975 & 3 & 3 & .6 & $0-2$ & 3 & & & & & \\
\hline
\end{tabular}

e refers to the minimum possible average for that year; i.e., by assuming that plants not commercial by 9/76 actually go commercial in $10 / 76$.

Source: Status of Central Station Nuclear Reactors - Significant Milestones, ERDA, September 1976. 
However, there is clear evidence that a major part of the increase in regulatory delay was due to bottleneck problems involving the staff and the Advisory Commission on Reactor Safety (ACRS). In 1966, uncontested applications could be processed in ten months or less; by 1970, it took a year and one-half or more simply to perform the staff and ACRS review preceding announcement of establishment of a licensing board and scheduling of prehearing conferences. This increase, it might be noted, occurred before the expansion of the scope of the CP review process to handle antitrust and environmental matters. No doubt a part of this bottleneck problem was indirectly related to intervention; it simply takes more staff time to prepare answers to issues that might be raised by intervenors in a contested hearing than would be the case in an uncontested hearing.

\section{Delays in Construction}

Licensing requirements were not, however, the only source of delay or of increasing costs. The Joint Committee on Atomic Energy warned in 1967 that manufacturers might have problems in delivering equipment on time and in meeting performance and safety standards. To keep up with nuclear demands, in October 1968, General Electric announced major expansion of two manufacturing divisions (Electrical World, October 28, 1968). Another NSSS manufacturer, Babcock and Wilcox, was reported to have problems in meeting delivery dates because of lack of capacity.

One contemporary study found the following reasons for delays in bringing nuclear units on line: 
1. Labor Trouble

28 plants

2. Licensing Delays

25 plants

3. Late Delivery of Pressure Vessels

21 plants

4. Public Opposition

16 plants

5. Construction Problems

16 plants

6. Scheduling Problems

6 plants

(Source: Electrical World, March 2, 1970).

Labor trouble, late delivery, construction and scheduling problems can all be interpreted as evidence of bottlenecks resulting from rapid expansion of damand for nuclear plants. Contemporary authorities recognized that equipment problems were epidemic, but favored the bottleneck hypothesis. The president of Westinghouse Power Systems, for example claimed that "much of the delay being experienced by some utilities is simply the result of the large influx of orders experienced in 1966-1967. Once this is behind us, plants should consistently come on line with five year lead time from order to operation." (Electrical World, September 1, 1970)

The Relation Between Estimated and Actual Costs: 1966-1970

Although licensing and construction delays were recognized in the nuclear industry, their full implications for nuclear costs did not appear in cost estimates by utilities until after 1970 . Between 1968 and 1971, estimates of nuclear capital costs were formed by utilities on the basis of historical experience: inflation and rising interest rates which appeared late in the sixties were not anticipated, delays were seen as largely a transitory phenomenon 
resulting from the great influx of orders in 1966 and 1967, and increasing the size of nuclear power units was expected to provide the economies of scale that had in the past been obtained by building larger fossil plants. It was not until 1972 and later that cost estimates begin to skyrocket in response to the observed fact that the 50 percent increase in estimates between 1966 and 1970 fell far short of the trend in realized costs.

The first published estimates of capital costs by the AEC was commissioned in March 1968, to be based on March 1967 data (WASH-1082). The study estimated that a $1000 \mathrm{MW}$ plant would cost about \$135/kw, a figure lower than 1968 estimates by electric utilities. The procedures used were seriously flawed -- the bill of materials was underestimated, the design of the plant was poorly defined, an unrealistically low interest rate was used, and zero inflation was assumed.

In a second part, published in June 1969 (WASH-1150), an attempt was made to determine the causes of the obvious increase in estimated cost. The WASH-1150 estimate of $\$ 250$ per kilowatt actually exceeded contemporary utility estimates. The reasons cited for cost increases were:

1. Higher direct costs, due to a revised description of the plant -- including additional safety systems -and higher prices of factor inputs.

2. Higher indirect costs (which included some construction costs), contingency reserves, and interest rates. 
3. Escalation of construction and manufacturing labor rates.

In January 1971 a new estimate of $\$ 350 / \mathrm{kw}$ was reported (WASH-1230). The increase was attributed to "latest safety requirements, codes, and standards..., environmental protection and licensing criteria." WASH-1230 also assumed an additional year of construction time and a higher interest rate. Utility estimates of nuclear costs lagged behind WASH-1230; the average reported for plants under construction in 1971 was on $1 \mathrm{y} \$ 300 / \mathrm{kw}$.

In Table 7 original estimates and actual realized costs of plants ordered in each year from 1965 to 1970 are compared. As Bupp (1974) has pointed out, not all of these plants have yet been completed, and estimates of costs for plants still in the operating license process when the data were assembled exceed the actual cost of completed plants.

The 1965 and 1966 cohorts were completed at an average cost twice the estimate. Costs of completed plants in the 1967 and 1968 cohorts range from two and one-half to three times the initial estimate, but it must be emphasized that these retrospective comparisons could not be made by utilities considering nuclear power plants in 1970 or 1971. They had only the historical experience of the utility industry with construction of fossil fueled power plants and four years of nuclear construction experience to rely on. Moreover, plants such as Connecticut Yankee and San Onofre had been completed on time and, to all appearances, under budget. 


\section{TABLE 7}

COMPARISON OF AVERAGE INITIAL ESTIMATES TO ESTIMATED AVERAGE ACTUAL COSTS OF NUCLEAR PLANTS BY YEAR OF ORDER

\section{Year of NSSS Order}

\author{
Average Initial \\ Estimate
}

Estimated Average Cost of Plants Completed by $1 / 77$

$\begin{array}{lll}1965 & 120 & 240 \\ 1966 & 125 & 240 \\ 1967 & 150 & 365 \\ 1968 & 155 & 460 \\ 1969 & 205 & \\ 1970 & 220 & \end{array}$

Source: Central Station Nuclear Plants, AEC and ERDA 1968-1976

Estimated Average cost of plants completed by $1 / 77$ uses WASH-1345 estimates of turnkey costs. 
A TIME OF CHANGE: 1971-1976

During the seventies initial estimates of the cost of newly ordered plants increased rapidly, from $\$ 200 / \mathrm{kw}$ during 1970 to almost $\$ 700 / \mathrm{kw}$ during 1975 . The fact that information on the actual costs of completed plants became available at almost exactly the time that new estimates shot up (see Figure 1) suggests that utilities were learning from experience. From 1971 on, year to year changes in updated estimates of the eventual costs of plants under construction increased at about the same pace as initial estimates.

But the actual costs of completed plants also increased rapidly during the seventies. During 1970 and 1971 many of the turnkey plants ordered before 1967 were completed; average reported costs in those years were about $\$ 125 / \mathrm{kw}$. Through 1974 reported costs increased at an average of $\$ 50$ per year. Plants completed in 1975 and early 1976 provided the real shock; the average cost of plants completed during 1975 was $\$ 425$ per kilowatt, compared to $\$ 300$ per kilowatt during 1974. And plants completed during 1976 cost on average $\$ 560$ per kilowatt.

These changes in real -- as opposed to estimated -- costs resulted from changes in the regulatory process and from external events which changed the whole environment in which utilities operated.

\section{The Regulatory Process}

Events in the regulatory process tend to increase capital costs in two general ways. First, regulation can increase costs 
through mandated changes in the design and construction of plants when regulatory guidelines are strenghtened or extended; such added costs reflect the substantive impact of regulation. Second, regulation can increase costs by imposing delays on the construction process, even when no changes take place in the design or construction of the plant; such costs represent the procedural effects of regulation. The most important procedural effects arise from changes in the length of time required to complete the licensing process. As that time increases, interest payments on prior expenditures accumulate and inflation drives up the cost of later procurements.

Table 4 revealed that the length of time spent in construction permit. processes alone was 29 months longer for a plant ordered in 1970 than for one ordered in 1966. The primary reason for licensing and construction delays from 1970 on was undoubted1y increasing attention to environmental and safety issues, much of which stemmed from intervenor activities in the licensing process. The Calvert Cliffs decision introduced a new dimension of environmental concern into licensing procedures. In 1971 the United States District Court ruled that the National Environmental Policy Act of 1969 required the AEC to consider alI environmental impacts of a nuclear plant in deciding to issue a construction permit or operating license. During 1971 the AEC began to implement this ruling, which required preparation of new environmental impact statements for all plants not yet in operation. By October 1972, Electrical World estimated that 48 plants had suffered construction delays since the effects of Calvert cliffs on 
schedules had become apparent.

Throughout the seventies the AEC issued increasingly stringent standards regulating environmental impacts and safety of nuclear plants under construction; additional delays resulted from AEC rulings which applied new standards to all nuclear plants. On June 15, 1971, Electrical World reported that five plants would be delayed in construction because of a new study of the Emergency Core Cooling System that would result in imposition of new requirements, adding $\$ 4$ million to the cost of a typical reactor. Another example of a substantive effect of nuclear regulation is the estimated increase of $\$ 12$ million in costs per plant for water intake structures, noise abatement measures, etc. mandated by the AEC in the 1971-1973 period.

It should be noted that there is some evidence (Indian Point 2, Surry 1, Electrical World, May 1, 1972; September 15, 1972) that delays and costs of rebuilding nuclear plants were due to inadequate initial design, as well as to the regulatory requirements.

During 1973 the AEC admitted that "... increases in reported power plants costs [have] continued to exceed expectations. Essentially all power plants under construction . . show large costs overruns..." The AEC identified the causes of cost overruns as:

1. Additional engineering. safety and environmental factors.

2. Increased costs, of al1 types

3. Increased escalation and interest due to longer project time. 


\section{Responses to Changing Circumstances}

During the early seventies utilities became aware of the serious underestimation of costs in early expectations about nuclear power.

From 1971 on, the year-to-year increase in cost estimates for new plants ranged from $\$ 75$ to $\$ 150$ per kilowatt. The average of reported costs showed a smaller annual increase, of $\$ 50$ per kilowatt, until 1975. Interim estimates of costs of plants under construction increased at about the same pace as initial estimates (see Table 5 and Figure 1 ).

Estimates of cost of plants ordered during 1975 reached an average of $\$ 700$ per kilowatt -- a figure which will still be low unless there is a sizable fall in historical escalation rates. Despite the rising estimates of nuclear costs, orders for nuclear plants rose from 1970 until 1973, and then fell off precipitously as indicated in Table 1. As early as 1972 some cancellations and deferrals were, however, reported. Two factors can be identified as explanations for the surge of nuclear orders in the early 70s. First, air quality regulations made construction

of fossil fueled plants appear expensive, infeasible, or at least, antisocial, in many areas of the country. Second, during the $70 \mathrm{~s}$ coal-fired power plants -- the most attractive alternative to nuclear power given the limitation on oil and gas supplies that devloped after 1970 -- were also increasing in costs, and coal fuel prices were rising as well. 
Table 8 presents data on coal and nuclear capital costs between 1968 and 1976 (1974 for coal). New nonturnkey nuclear units coming on line in 1972 had capital costs that were 70 percent higher than those for new coal units, with the differential reduced to roughly 50 percent higher in 1973-1974. While nuclear capital costs for units coming on line show a high rate of escalation (between 25 and 30 percent per year over the past few years), there has also been a marked rate of escalation in coal capital costs as we11. As noted earlier, due to the 1ong and variable gestation period for nuclear units, data on units coming on line tend to understate the average capital costs for any cohort of plants, so that as dramatic as are the cost changes shown, in fact capital costs were escalating even more rapidly than indicated. Offsetting this was the increase in capital costs for coal, coupled with technological and cost uncertainties as to the new environmental controls (scrubbers, cooling towers, etc.) that were beginning to be applied to coal units.

Moreover, after remaining almost constant for many years, coal fuel prices began to rise dramatically during the late sixties. At first the rise in prices was driven by increasing labor costs in coal-mining which resulted from new standards protecting miners' health and safety. The rise in coal prices played an important role in continued viability of nuclear power through 1973. Then a strike reduced mine output during 1973 at the same time that rising oil prices led some utilities to increase their demand for coal. A 300 percent increase in spot prices during 1974 resulted; many 
TABLE 8

HISTORICAL CAPITAL COST DATA, 1968-1976 NUCLEAR AND COAL POWER PLANTS

\begin{tabular}{|c|c|c|c|c|c|c|c|c|c|c|c|c|}
\hline \multirow[b]{2}{*}{ Year } & \multicolumn{3}{|c|}{$\begin{array}{l}\text { Number of Units } \\
\text { Coming on Line }\end{array}$} & \multicolumn{3}{|c|}{$\begin{array}{l}\text { Average MWe per } \\
\text { Unit Coming on Line }\end{array}$} & \multicolumn{3}{|c|}{ CapitaI Cost $\$ / K W$} & \multicolumn{3}{|c|}{ Range Capital Cost \$/KW } \\
\hline & $\mid \begin{array}{l}\text { Nuclear } \\
\text { Non-Turn }\end{array}$ & $\begin{array}{l}\text { Nuclear } \\
\text { Turn }\end{array}$ & Coal & $\begin{array}{l}\text { Nucl } \\
\text { Non-T }\end{array}$ & $\begin{array}{l}\text { Nuc1 } \\
\text { Turn }\end{array}$ & Coal & $\begin{array}{l}\text { Nuc1 } \\
\text { Non-T }\end{array}$ & $\begin{array}{l}\text { Nucl } \\
\text { Turn }\end{array}$ & Coal & $\begin{array}{l}\text { Nucl } \\
\text { Non-T }\end{array}$ & $\begin{array}{l}\text { Nuc1 } \\
\text { Turn }\end{array}$ & Coa1 \\
\hline 1968 & -- & $2(\mathrm{~N})$ & $\begin{array}{r}9(\mathrm{~N}) \\
17(\mathrm{~A})\end{array}$ & --- & $525(\mathrm{~N})$ & $\begin{array}{l}344(\mathrm{~N}) \\
360(\mathrm{~A})\end{array}$ & --- & $164(\mathrm{~N})$ & $\begin{array}{l}117(\mathrm{~N}) \\
132(\mathrm{~A})\end{array}$ & ---- & $\begin{array}{l}153- \\
180\end{array}$ & $\begin{array}{l}72- \\
184\end{array}$ \\
\hline 1969 & $1(\mathrm{~N})$ & $1(\mathrm{~N})$ & $\begin{array}{l}13(\mathrm{~N}) \\
17(\mathrm{~A})\end{array}$ & $620(\mathrm{~N})$ & $550(\mathrm{~N})$ & $\begin{array}{l}382(\mathrm{~N}) \\
486(\mathrm{~A})\end{array}$ & $262(N)$ & $163(\mathrm{~N})$ & $\begin{array}{l}140(\mathrm{~N}) \\
114(\mathrm{~A})\end{array}$ & 262 & 163 & $\begin{array}{l}79- \\
192\end{array}$ \\
\hline 1970 & -- & $\begin{array}{l}2(\mathrm{~N}) \\
1(\mathrm{~A})\end{array}$ & $\begin{array}{l}13(\mathrm{~N}) \\
10(\mathrm{~A})\end{array}$ & --- & $\begin{array}{l}520(\mathrm{~N}) \\
810(\mathrm{~A})\end{array}$ & $\begin{array}{l}488(\mathrm{~N}) \\
472(\mathrm{~A})\end{array}$ & --- & $\begin{array}{l}151(\mathrm{~N}) \\
114(\mathrm{~A})\end{array}$ & $\begin{array}{l}157(\mathrm{~N}) \\
113(\mathrm{~A})\end{array}$ & ---- & $\begin{array}{l}114- \\
161\end{array}$ & $\begin{array}{l}83- \\
205\end{array}$ \\
\hline 1971 & $1(\mathrm{~N})$ & $\begin{array}{l}2(\mathrm{~N}) \\
2(\mathrm{~A})\end{array}$ & $\begin{array}{l}11(\mathrm{~N}) \\
11(\mathrm{~A})\end{array}$ & $812(\mathrm{~N})$ & $\begin{array}{l}615(\mathrm{~N}) \\
785(\mathrm{~A})\end{array}$ & $\begin{array}{l}693(\mathrm{~N}) \\
507(\mathrm{~A})\end{array}$ & $181(\mathrm{~N})$ & $\begin{array}{l}170(\mathrm{~N}) \\
115(\mathrm{~A})\end{array}$ & $\begin{array}{l}128(\mathrm{~N}) \\
120(\mathrm{~A})\end{array}$ & 181 & $\begin{array}{l}101- \\
185\end{array}$ & $\begin{array}{l}96- \\
216\end{array}$ \\
\hline 1972 & $\begin{array}{l}4(N) \\
1(\mathrm{~A})\end{array}$ & $\begin{array}{l}1(\mathrm{~N}) \\
2(\mathrm{~A})\end{array}$ & $\begin{array}{r}7(\mathrm{~N}) \\
14(\mathrm{~A})\end{array}$ & $\begin{array}{l}712(\mathrm{~N}) \\
760(\mathrm{~A})\end{array}$ & $\begin{array}{l}879(\mathrm{~N}) \\
701(\mathrm{~A})\end{array}$ & $\begin{array}{l}665(\mathrm{~N}) \\
556(\mathrm{~A})\end{array}$ & $\begin{array}{l}274(\mathrm{~N}) \\
143(\mathrm{~A})\end{array}$ & $\begin{array}{l}121(\mathrm{~N}) \\
129(\mathrm{~A})\end{array}$ & $\begin{array}{l}174(\mathrm{~N}) \\
160(\mathrm{~A})\end{array}$ & $\begin{array}{l}143- \\
353\end{array}$ & $\begin{array}{l}121- \\
136\end{array}$ & $\begin{array}{l}115- \\
244\end{array}$ \\
\hline 1973 & $\begin{array}{l}4(\mathrm{~N}) \\
3(\mathrm{~A})\end{array}$ & - & $\begin{array}{r}8(\mathrm{~N}) \\
14(\mathrm{~A})\end{array}$ & $\begin{array}{l}765(\mathrm{~N}) \\
873(\mathrm{~A})\end{array}$ & & $\begin{array}{l}562(\mathrm{~N}) \\
652(\mathrm{~A})\end{array}$ & $\begin{array}{l}293(\mathrm{~N}) \\
184(\mathrm{~A})\end{array}$ & & $\begin{array}{l}204(\mathrm{~N}) \\
157(\mathrm{~A})\end{array}$ & $\begin{array}{l}161- \\
393\end{array}$ & --- & $\begin{array}{l}115- \\
307\end{array}$ \\
\hline 1974 & $\begin{array}{l}4(\mathrm{~N}) \\
5(\mathrm{~A})\end{array}$ & - & $\begin{array}{l}10(\mathrm{~N}) \\
10(\mathrm{~A}) \\
\end{array}$ & $\begin{array}{l}811(\bar{N}) \\
914(\mathrm{~A})\end{array}$ & --- & $\begin{array}{l}565(\mathrm{~N}) \\
693(\mathrm{~A}) \\
\end{array}$ & $\begin{array}{l}347(\mathrm{~N}) \\
320(\mathrm{~A})\end{array}$ & --- & $\begin{array}{l}230(\mathrm{~N}) \\
172(\mathrm{~A})\end{array}$ & $\begin{array}{l}191 \\
546 \\
\end{array}$ & -- & $\begin{array}{l}136- \\
312 \\
\end{array}$ \\
\hline 1975 & $\begin{array}{l}7(\mathrm{~N}) \\
3(\mathrm{~A})\end{array}$ & - & NA & $\begin{array}{l}875(\mathrm{~N}) \\
905(\mathrm{~A}) \\
\end{array}$ & --- & NA & $\begin{array}{l}436(\mathrm{~N}) \\
408(\mathrm{~A})\end{array}$ & --- & NA & $\begin{array}{l}251- \\
518\end{array}$ & --- & NA \\
\hline 1976 & $3(\mathrm{~N})$ & - & NA & $914(\mathrm{~N})$ & -- & NA & $560(\mathrm{IN})$ & --- & NA & $\begin{array}{l}415- \\
692\end{array}$ & --- & NA \\
\hline
\end{tabular}

Number of units coming on 1ine, coal, is the number of new coal units reported in Steam Electric Plant Construction Cost and Annual Production Expenses, FPC, 1968-1974. Nuclear units, non-turnkey and turnkey are from Central Station Nuclear P1ants, AEC and ERDA, 1968-1976.

$(\mathrm{N})$ and (A) in the units coming on line columns refer to new plants and additions to existing plants respectively.

Capital Cost \$/KW, for coal, are FPC figures, 1968-1974; nuclear data are from FPC, 1968-1974, and from Central Station Nuclear Plants, 1975, 1976. 
utilities were cut off from coal promised under long-term contracts as suppliers diverted coal to the more profitable spot market. The importance of the oil embargo and resulting increases in all fuel prices goes without saying, of course.

By 1975 coal prices had stabilized at a level about twice that reached in the mid-60s. Coal remained about one-half the price (per million BTU's heating value) of oil, and supplies were adequate to meet utility demand.

On net balance, developments through the early 70 s apparently favored expansion of nuclear capacity for baseload plants. But as early as 1972, there were indications that the rate of escalation of nuclear capital costs was beginning to tip the scales in favor of coal.

In 1972, several utilities cited nuclear cost increases and construction delays as reasons for reversing earlier decisions and choosing coal over nuclear (Florida $\mathrm{P} \& \mathrm{~L}$, Iowa $\mathrm{P} \& \mathrm{~L}$ ). During 1972 three nuclear units were canceled, one in favor of a coal fueled facility. During 1973 another reason for cancellations and deferrals became apparent -- rising costs and inadequate revenues were making utilities unable or unwilling to finance capacity expansion. On March 1, 1973, Georgia P \& L announced deferral of two nuclear units because of financial strains resulting from denial of a request for a rate increase. Seven outright cancellations reported in 1973 were attributed, at least in part, to environmental opposition. In 1974 still a third reason for cancellations and deferrals became apparent -- the unprecedented slowdown in electricity demand 
growth that resulted from rising energy prices, recession, and mild weather. Electrical World (September 15, 1974) stated that throughout the industry, "Rescheduling of generating additions approaches landslide proportions as U.S. utilities move to align capital expenditures with lower than expected load growth." Generating capacity was projected to grow faster than load through 1976 despite announced cutbacks.

Because of their high capital cost and long lead times, nuclear plants were particularly vulnerable to financing problems and cutbacks due to inadequate demand. Electrical Wor1d (October 15, 1974) estimated that 36 percent of a11 nuclear units under construction had their schedules set back during 1974. A few were reported to be plants suffering construction delays, but most were reported to be victims of "utility ordered stretchouts averaging two years."

As utility financial problems eased during late 1975 and 1976, general construction plans recovered, but coal orders remained low while nuclear cancellations exceeded new orders. It is difficult to say whether this represents a temporary legacy of low demand and financial difficulties of 1974 and 1975 , or a permanent shift away from nuclear power.

CAUSES FOR NUCLEAR CAPITAL COST INCREASES, 1966-1976

It might be well to place the cost history of nuclear power reactors in perspective through comparisons with other indicators for the 1967-1976 period. Table 9 shows that the GNP 
TABLE 9

PRICE INDICES AND INTEREST RATES, 1967-1976

\begin{tabular}{|c|c|c|c|c|c|c|}
\hline \multirow[b]{2}{*}{ Year } & \multicolumn{2}{|c|}{$\begin{array}{l}\text { GNP. Price Index } \\
(1972=100) \\
\end{array}$} & \multicolumn{2}{|c|}{$\begin{array}{l}\text { Construction } \\
\text { Price Index } \\
(1967=100)\end{array}$} & \multirow{2}{*}{$\begin{array}{l}\text { Net Yield } \\
\text { Moody's Aaa } \\
\text { Corp. Bonds } \\
\end{array}$} & \multirow{2}{*}{$\begin{array}{l}\% \text { Change in } \\
\text { KWe Cost of } \\
\text { Nuclear Units } \\
\text { Coming on Line }\end{array}$} \\
\hline & Index & $\%$ Change & Index & $\%$ Change & & \\
\hline 1967 & 79.0 & +2.9 & 100.0 & +1.2 & 5.51 & - \\
\hline 1968 & 82.6 & +4.5 & 104.9 & +4.9 & 6.18 & - \\
\hline 1969 & 86.7 & +5.0 & 110.8 & +5.9 & 7.03 & $\mathrm{n} \cdot \mathrm{a}$. \\
\hline 1970 & 91.4 & +5.4 & 112.6 & +1.7 & 8.04 & $\mathrm{n} \cdot \mathrm{a}$. \\
\hline 1971 & 96.0 & +5.1 & 119.7 & +6.3 & 7.39 & n.a. \\
\hline 1972 & 100.0 & +4.1 & 126.2 & +5.4 & 7.21 & n.a. \\
\hline 1973 & 105.8 & +5.8 & 136.7 & +8.4 & 7.44 & +6.0 \\
\hline 1974 & 116.4 & +10.0 & 161.6 & +18.2 & 8.57 & +44.2 \\
\hline 1975 & 127.3 & +9.3 & 176.4 & +9.2 & 8.83 & +30.1 \\
\hline 1976 & 133.8 & +5.1 & 187.9 & +6.5 & 8.43 & +30.9 \\
\hline $1967-1976$ & & +69.4 & $1967-1976$ & +87.9 & & \\
\hline $1972-1976$ & & +33.8 & $1972-1976$ & +48.9 & $1972-1976$ & +136.3 \\
\hline
\end{tabular}

Source: GNP price index, construction price index, and yields from the Economic Report of the President, January 1977; change in cost of nuclear units is taken from Table 8 , except that data for the turnkey years(1968-1971) is excluded, and the 1972 average cost $(\$ / \mathrm{kw})$ excludes the two turnkey units completed in 1972 . 
implicit price index increased by 69 percent between 1967 and 1976, and the construction price index increased by 88 percent. Capital cost per $\mathrm{kw}$ for nuclear units coming on line rose by 136 percent between 1972 and 1976 alone; data for the early years are suppressed due to the known problems with turnkey reported costs. Between 1967 and 1976, the interest rate on AAA bonds rose from 5.51 percent to 8.43 percent, an increase of roughly 53 percent. If construction costs for nuclear units had risen at the average rate for the construction industry as a whole, and if interest costs (roughly 17 percent of total costs for a nuclear unit, according to WASH-1345, but now near 30 percent of total costs due to lengthened completion times) had risen simply to reflect the increase in interest rates, then the cost of a nuclear unit would have roughly doubled between 1967 and 1976 and would have risen by perhaps 60 percent between 1972 and 1976 rather than the 136 percent increase indicated by the last colum of Table 9 . The difference is accounted for by several factors:

1. Nuclear units being built in the 1970 s were different from those being built in the 1960s, because of new safety and environmental requirements.

2. The time required to complete the licensing-construction process for new units coming on line increased from five years in 1967 to nine years in 1976, and wil1 be even longer for units still in the pipeline. 
3. Rising interest rates interacted with delays to increase interest charges.

4. Because of bottleneck problems, labor and material cost increased much more in nuclear construction than in construction in general.

5. Licensing costs rose substantially over the period.

The leading study that has addressed itself to analyzing the relative importance of these factors is the study by Bupp ${ }^{7}$. Bupp's work has been complemented by studies undertaken by the $\mathrm{AEC}$, and by the utility industry and contractors.

Bupp finds that one driving factor in cost increases was the increase between 1965 and 1975 in manpower and raw material requirements of nuclear power plants. 8 Bupp interprets this increase to be "obviously a consequence of more stringent nuclear safety and environmental design criteria," but asserts that the increase in reactor construction time is thought to be more important. Bupp divides total project length into licensing time -the time between application for and issuance of the construction permit -- and on-site construction time -- the interval between beginning of site preparation and operation of the reactor. He finds that "an increase in the 1icensing time has a strong effect on total costs" but that the relationship between total costs and on-site construction time is insignificant. 
Bupp gives two reasons why increases in the licensing period might increase total costs: (1) the length of the licensing period measures the stringency of design changes and safety features that are required; (2) long licensing periods lead the utility to speed construction to make up for licensing delays, with consequent increases in costs. Bupp observes that this may also explain the lack of correlation between on-site construction time and costs. In summary, Bupp identifies the major factor behind the differential rate of increase in nuclear costs to be the activities of intervenors; he concludes that the nuclear licensing process has been used by opponents of nuclear power as a vehicle for raising the private cost of nuclear power to the perceived level of social cost.

WASH-1345, ${ }^{9}$ published by the AEC in October 1974, represents an alternative approach to the nuclear cost issue. Rather than attempting to identify underlying causal factors, WASH-1345 undertook a retrospective study of cost increases between 1966 and 1974 by estimating costs, by categories, for nuclear units coming on line during those periods. Escalation of labor and material costs and increases in interest during construction were identified as the major components of cost increase between 1966 and 1974. In addition, the study found that direct construction costs more than doubled over the period, with about $\$ 90$ million in cost of a hypothetical $1000 \mathrm{MW}$ plant ordered in $1973(\$ 90 / \mathrm{kw})$ being due to environment and safety related changes in plant design mandated between 1971 and 1973 . 
Because the approaches are different, there is no necessary conflict between these conclusions; and because nuclear units are so site specific in characteristics and so lacking in standardization, neither study can be said to represent a definitive answer to the question of the source of cost increases between 1966 and 1974. That licensing problems represent a major source of cost increases from 1970 on is clearly correct, and that bottleneck problems have been present throughout the history of the industry is also true. But the conclusion of Bupp's study that intervenors are to be assigned the major role in the explanation of cost increases deserves further comment.

Intervention in the licensing process became the normal pattern from 1969 on; prior to that time, uncontested licensing hearings were as common as hearings in which intervenors appear. Table 10 gives data on construction permit applications between 1966 and 1970.

The average time required to complete the CP process rose from 10.5 months in 1966 to 37.7 months in 1970 , and the percent of uncontested hearings drops noticeably between those dates. But the average time required for an uncontested hearing rose from 8.7 months in 1966 to 28.3 months for plants applying for a CP in 1970, which strongly suggests that intervention was not the only factor at work in lengthening the licensing time. Contested hearings, on average, required more time than did uncontested hearings; intervention is associated with time delays. But bottlenecks in the licensing process and changes in 
TABLE 10

CP APPLICATIONS

1966-1970

\begin{tabular}{|c|c|c|c|c|c|c|}
\hline & \multicolumn{2}{|c|}{ CP Applications } & \multicolumn{2}{|c|}{ Uncontested } & \multicolumn{2}{|c|}{ Contested } \\
\hline & No. & $\begin{array}{l}\text { Avg. Time } \\
\text { (Months) }\end{array}$ & No. & $\begin{array}{c}\text { Avg. Time } \\
\text { (Months) } \\
\end{array}$ & No. & $\begin{array}{c}\text { Avg. Time } \\
\text { (Months) }\end{array}$ \\
\hline 1966 & 13 & 10.5 & 7 & 8.7 & 6 & 13.8 \\
\hline 1967 & 21 & 13.2 & 10 & 13.7 & 11 & 13.0 \\
\hline 1968 & 9 & 22.8 & 5 & 16.0 & 4 & 31.3 \\
\hline 1969 & 9 & 26.5 & 1 & 41.0 & 8 & 25.0 \\
\hline 1970 & 12 & 37.7 & 3 & 28.3 & 9 & 40.8 \\
\hline
\end{tabular}

Source: Status of Centra1 Station Nuclear Power

Reactors, Significant Milestones, ERDA-30, July 1976 . 
rules and regulations unrelated to intervention also clearly played a role in regulatory delays, especially prior to 1971 .

It is instructive to look at the case histories of the units applying for CPs during this period, in an attempt to identify the causes of this increase in regulatory delays. Appendix B presents a capsule history of the CP licensing process for each unit entering CP licensing during the 1966-1970 period. It is arranged so that in each year, the units are ranked in terms of the delays experienced in obtaining a CP. It should first be noted that, in general, it is not easy to pinpoint the source of delay in any specific case. Intervenors can delay issuance of a CP by enlarging the scope of issues to be considered by a licensing board, thus increasing the number and time duration of prehearing conferences and hearings; but often those or related issues are also the subject of some disagreements among the staff, ACRS and the licensing board as well, and might have caused delays even in the absence of intervention. It is important to note that appeals after a CP has been issued, whether appeals to the ASLB or the AEC or to the courts, have no effect on delaying construction unless a stay is granted, a relatively rare occurrence. Thus there are many cases of very active intervention, involving many appeals and many issues, but with relatively short time delays in obtaining a CP.

Some general comments are in order concerning the information presented in Appendix B. First, intervention is essentially never completely successful in the sense that a license is refused 
by an LB. In fact, there are no cases of this occurring during the 1966-1970 period, and none we are aware of in the history of the AEC-NRC. Second, intervention is rarely successful in the sense of changing the location of a reactor or challenging the safety and/or environmental features associated with construction; but there are a few cases in which licenses are conditioned to take into account issues raised by intervenors. Historically there have been cases, such as Malibu, where the conditions imposed were sufficiently restrictive so that the unit was withdrawn after obtaining a CP subject to such conditions. Thirdly, intervenors have been more successful (if that in fact is their goal) in increasing the costs of constructing a reactor, by imposing time delays and by imposing informational costs on a utility. A striking case of that is Bailly, a unit to be located near Dunes State Park in Indiana, which went through a long and bitter $\mathrm{CP}$ hearing, after which various stays have been imposed on construction through court actions.

The primary success of intervenors has been generic rather than specific to individual plants. As indicated in Appendix B, contested hearings in 1966-1968 often involved the issue of "practical value" of nuclear units, with small utilities and municipalities attempting to intervene to force antitrust hearings. This led to Congressional action in 1970 mandating an antitrust review of all units entering the nuclear licensing process. Similarly, environmental issues raised in the later 1960s led finally to the incorporation of an environmental review as a part of the $\mathrm{CP}$ issuing process. No doubt antitrust review and 
environmental review can, in certain cases at least, provide substantive relief to complaints of intervenors. But these reviews also increase the overall time delays associated with licensing and hence the cost of reactors, so that they also play a role in decreasing the economic advantages of nuclear power. The history of the 1966-1970 period was not simply one of intervenors entering the licensing process and automatically imposing delays on plant licensing. But after 1970 the success of intervenors on generic issues led to substantial cost increases to meet new design and safety requirements. Moreover, Calvert Cliffs led to major time delays in preparing environmental impact statements and in hearings on such statements.

OPERATING COSTS OF NUCLEAR AND COAL UNITS

Finally, some comments should be made about the total costs of generating electricity using nuclear units as compared to coal units. Cost-benefit analyses of nuclear units have typically assumed an 80 percent plant factor (output/capacity) for these base load plants, and the AEC has historically employed comparably high plant factors in its comparisons of costs between coal and nuclear. The higher is the plant factor, the lower are capital costs per unit of output, so that high plant factors lead to a more favorable cost comparison for nuclear units relative to coal.

As ear1y as the mid-60s, some utility managers were expressing skepticism concerning the assumption that nuclear units 
could operate in the 80 percent range.

A recent study found that capacity factors deteriorated with the increasing scale of new plants, as a result of equipment malfunctions and difficulty in effecting repairs. ${ }^{10}$ The deterioration was found to be so rapid that capital costs per kilowatt-hour generated actually increase with increasing scale above about 800 MWe. Komanoff also found that coal plants had somewhat better performance than nuclear plants when an optimum size coal plant is compared to a nuclear plant of optimum size (optimum being defined as the size at which capital costs per kilowatt-hour are minimized, with the reduced cost due to scale economies in construction being just balanced by the increased cost due to poorer operating performance). Komanoff's conclusions are based on a relatively small data base and are disputed by utility spokesmen and reactor manufacturers, who argue that the shakedown period for large reactors has not yet been completed in the reactors currently operating, and that higher plant factors and lower costs will be observed in future years.

FPC data on nuclear and coal units coming on line between 1968 and 1973 (presented in Table 11) indicate that while nuclear units have not met the 80 percent plant factor goal, nonetheless operating costs and total costs (including capital cost) per unit of output were less on average for nuclear than coal.

Coal units coming on line in 1968 operated at a plant factor of roughly 55 percent between 1969 and 1974, while nuclear units of the same vintage had an average plant factor of roughly 
TABLE 11

HISTORICAL OPERATING COST COMPARISON, 1968-1973 NUCLEAR AND COAL POWER PLANTS

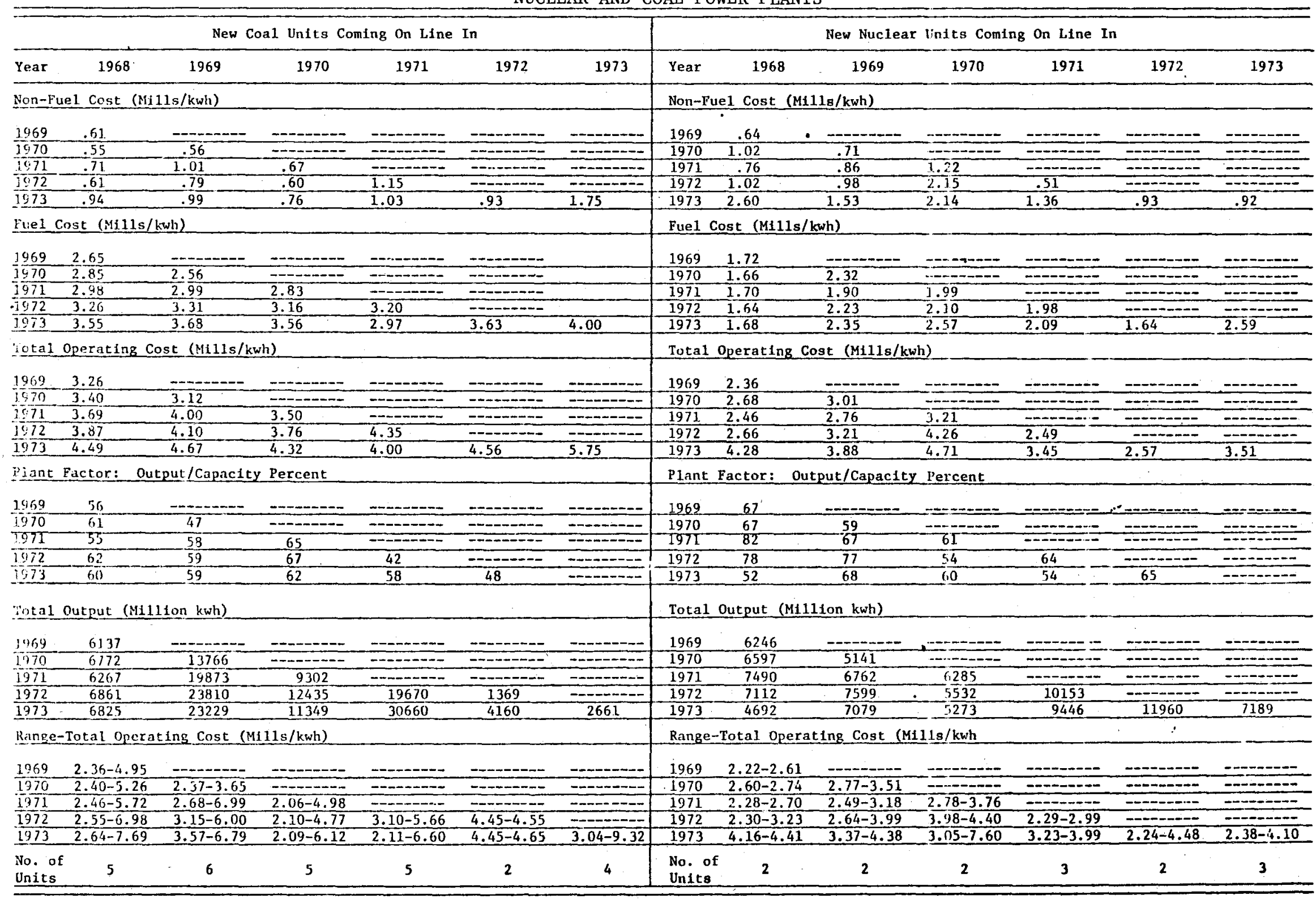

Source: Steam Electr1c Plant Construction Cost and Annual Production Expenses, FPC annual 1s8ues, $1968-1973$.

Data are shown only for new units for which no additions to capacity occurred between time of installation and 1973 . Each unit 10 veighted by ite output each year in arriving at average costs and plant factoro. 
70 percent. In 1974 , operating cost/kwh for 1968 vintage coal units was $5.87 \mathrm{mills}$, while for 1968 nuclear units, cost was $2.74 \mathrm{mills}$; and for 1969 vintage plants, the costs were $7.02 \mathrm{mills} / \mathrm{kwh}$ for coal versus $5.12 \mathrm{mills} / \mathrm{kwh}$ for nuclear. A similar operating cost advantage applies for later vintage units.

The basis for the observed cost advantage for nuclear units is low fuel cost, which is not completely offset by higher capital costs for nuclear units than coal units. Using a 16 percent fixed charge rate together with the observed plant factors for coal and nuclear units of 1972 and 1973 vintage, total cost (mills/kwh) in 1974 was 13.43 for 1972 vintage coal units and 12.49 for 1972 nuclear units; total cost in 1974 was $18.42 \mathrm{mills} / \mathrm{kwh}$ for 1973 vintage coal units versus $14.56 \mathrm{mills} / \mathrm{kwh}$ for 1973 vintage coal units. Thus as of 1974, the most recent year for which FPC coal capital cost data are available, new nuclear units were producing electricity more cheaply than new coal units. ${ }^{11}$ 
FOOTNOTES

1. The use of average capital cost per $k w$ as an index of the cost of nuclear units suffers from the problem of lack of standardization of such units. It is well known that costs can differ substantially on the basis of region of the country or whether construction labor is union or nonunion for example. Because the number of units coming on line each year is so sma11, major distortions can be introduced by such factors. For this reason both average cost $\$ / k w$ and the range of costs are shown in Table 3 .

Also it should be emphasized that costs of units coming on line include dollars of varying purchasing power, since expenditures are spread out over a number of years. Moreover, the rate of increase in costs of nuclear units coming on line underestimates the "true" rate of cost increases, since for any cohort of plants, the cheapest tend to be those that come on line earliest, as pointed out by Bupp (1974).

2. See H. Stuart Burness, W. David Montgomery and James P. Quirk, "The Turnkey Era in Nuclear Power," Social Science Working Paper No. 175, California Institute of Technology, August 1977. Also see "Development and Commercialization of the Light Water Reactor, 1946-1976," Robert Perry, et a1, Rand Corporation, R-2180-NSF, June 1977. 
3. There is some confusion in the literature concerning the number and identification of the turnkey plants. Mooz (1976) lists 13 plants built by General Electric and Westinghouse, al1 contracted for between 1962 and 1966, as turnkey units: Dresden 2, 3, Connecticut Yankee, San Onofre 1, Ginna, Oyster Creek, Millstone 1, Point Beach 1, 2, Robinson 1, Montice11o, and Quad Cities 1, 2. ERDA lists an additional 12 units as turnkey, for a total of 25: Big Rock Point, Dresden 1, Yankee Rowe, Humboldt Bay, Peach Bottom 1, Pathfinder, Piqua, Genoa, Fort St. Vrain, Indian Point 2, 3, Northcoast Power. Of these, all except the last four were development reactors built before 1962, and Northcoast Power was later canceled. Further, in WASH-1345, Indian Point 2 is listed as one of 13 turnkey units but Connecticut Yankee is not listed as a turnkey. Generally, we have used Mooz' classification.

4. While GE and Westinghouse ceased to offer fixed price contracts for nuclear units in mid-1966, both continued to offer fixed price contracts for nuclear fuel. Westinghouse's problems with its fuel contracts are well known; General Electric followed a less ambitious program, but for certain units (including Oyster Creek and Browns Ferry) guaranteed fuel price contracts for periods up to 12 years of plant operations were signed. The major difference between General Electric and Westinghouse was that General Electric followed the practice of covering its fuel commitments through forward purchases, while Westinghouse generally remained in an unhedged position. 
5. Moreover, in Mooz' discussion of the turnkey era, an executive of Westinghouse is quoted to the effect that San Onofre "came in under budget on time, and made a good profit," while Connecticut Yankee "also returned a modest profit." In contrast, the WASH-1345 estimates show Westinghouse 1osing $\$ 91$ million on these two units.

6. This is a highly simplified version of Mooz' view of the turnkey era. The same viewpoint was expressed at the time by Philip Sporn, president of American Electric Power: "Competitive levels of nuclear plants may not be quite so low as initial announcement had seemed to indicate. One of the effects of competition might be to induce a manufacturer to risk somewhat greater uncertainty in the costs behind his turnkey price than might be tolerable repeatedly." (Electrical World, August 17, 1964)

7. Bupp, I., Derian, J., Donsimoni, M., Treite1, R., "Trends in Light Water Reactor Capital Costs in the United States: Causes and Consequences," CPA 74-8, December 1974, Center for Policy Alternatives, Massachusetts Institute of Technology, Cambridge, Massachsuetts.

For a contrasting view of cost trends, see 1977 Update, Power Plant Economics, H. Brush, Bechtel Power Corporation, January 21, 1976, and Economics of Nuclear Power, W. Davis, Bechte1 Power Corporation, January 13, 1975. 
8. Bupp estimates that the cost per kilowatt of plants completed before 1975 increased at a rate of $\$ 49$ per year when the effects of gross geographical and design differences between plants completed in different years are statistically controlled, and $\$ 27$ when they are not. These estimates cannot be compared direct1y to Figure 1, because Bupp deflated all costs using the Handy-Whitman index of construction costs. We suspect that such deflation is inappropriate: the Handy-Whitman index is based, in part, on nuclear plant costs. Consequently, some cost changes which need to be explained vanish because of the deflator Bupp uses.

9. Atomic Energy Commission, "Power Plant Capital Costs: Current Trends and Sensitivity to Economic Parameters," WASH-1345, Washington, October 1974.

10. Komanoff, C., Power Plant Performance: Nuclear and Coal Capacity Factors and Economics, Council on Economic Priorities, New York, 1976.

Komanoff's conclusions are critized on an item by item basis in "The Edison Electric Institute's Comments and Critique of the Council on Economic Priorities Report Power Plant Performance and its later Update," Edison Electric Institute, July 1977. 
11. The nuclear units had, however, taken longer to complete. If substitute power were required because of nuclear delays, its cost could have reduced the nuclear advantage. Comparison of nuclear and coal units announced in the same year is impossible because of lack of cohort data on coal. 


\section{APPENDIX A}

CAPITAL COST DATA FOR NUCLEAR UNITS

The two basic sources of information on capital costs of nuclear units are Steam Electric Plant Construction Cost and Annual $\underline{\text { Production Expenses, Federal Power Commission; and Central Station }}$ Nuclear Plants, AEC/ERDA. The FPC publication appears on an annual basis and covers all steam plants (coal, oil, gas, turbine, nuclear), while Central Station Nuclear Plants appeared monthly (through early 1977), but is limited to nuclear units only. Data on capital costs appearing in the FPC publication are those reported by the utility to the FPC on a standardized basis that applies to all utilities. Data appearing in the AEC/ERDA publications are somewhat more uncertain in origin; most cost estimates are apparently supplied by the utilities, but in certain cases they represent estimates made by AEC/ERDA personnel.

Idea11y, time trends in nuclear capital costs would be based on FPC data. Unfortunately, the FPC tends to be quite late in publishing its annual Construction Cost and Production Expenses volume. In fact, the latest to appear as of late 1977 was the volume for 1974 . Given the brief history of commercial size nuclear units, using only FPC data would limit the analysis to only five or six years. Moreover when one adds to this that turnkey units dominate the picture through 1971, only three years of reliable cost data would be available for an historical overview, not a particularly happy situation. 
We decided to use AEC/ERDA cost figures for 1975 and 1976 in the tables presented in the body of this paper, which permits an extension of time trends up through 1976. We recognize that there might be distortions introduced into the analysis by the use of AEC/ERDA data to supplement the more reliable FPC figures, but there appeared to be no other alternative if any meaningful intertemporal comparisons were to be made. Appendix Table A-1 presents a comparison between FPC data and AEC/ERDA data on a unit by unit basis for each year between 1968 and 1974, the years for which both data sources are available. It will be noted that differences exist for almost all units, either in terms of rated capacity, total capital cost, capital cost per $\mathrm{kw}$, or in terms of the year during which the unit goes on line. Certain of these differences no doubt simply reflect definitional matters (e.g., for the AEC, a unit goes on line when it completes its commercial testing phase, while for the FPC, the date is related to the entrance of the unit to the rate base); while others arise from different reporting sources or the time at which the measurement is taken. It should also be pointed out that in the FPC tables, capital costs continue to increase over time even after a unit has come on line, reflecting various additions made to the unit after it goes commercial; hence there really is no such thing as "the" capital cost of a unit, independent of the time at which the capital cost is calculated. We have used the capital costs as of the year during which a unit goes on line as "the" capital cost of the unit. Moreover, the FPC tables do not give separate data on capital costs of additional units added to an existing unit; 
this must be calculated as the change in total capital cost for the plant between the year the new unit comes on line and the previous year. Unfortunately, there is no way to separate out the increase over time in the capital cost of the old unit from the increase in total capital cost due to the new unit. In Table A-1, any cost increase during the year a unit comes on line is assigned to the new unit, and this might account for a part of the difference between the FPC cost figures and those of the AEC/ERDA. 
TABLE A-1

CAPITAL COSTS OF NUCLEAR UNITS

COMING ON LINE, 1968-1974

FPC AND AEC/ERDA

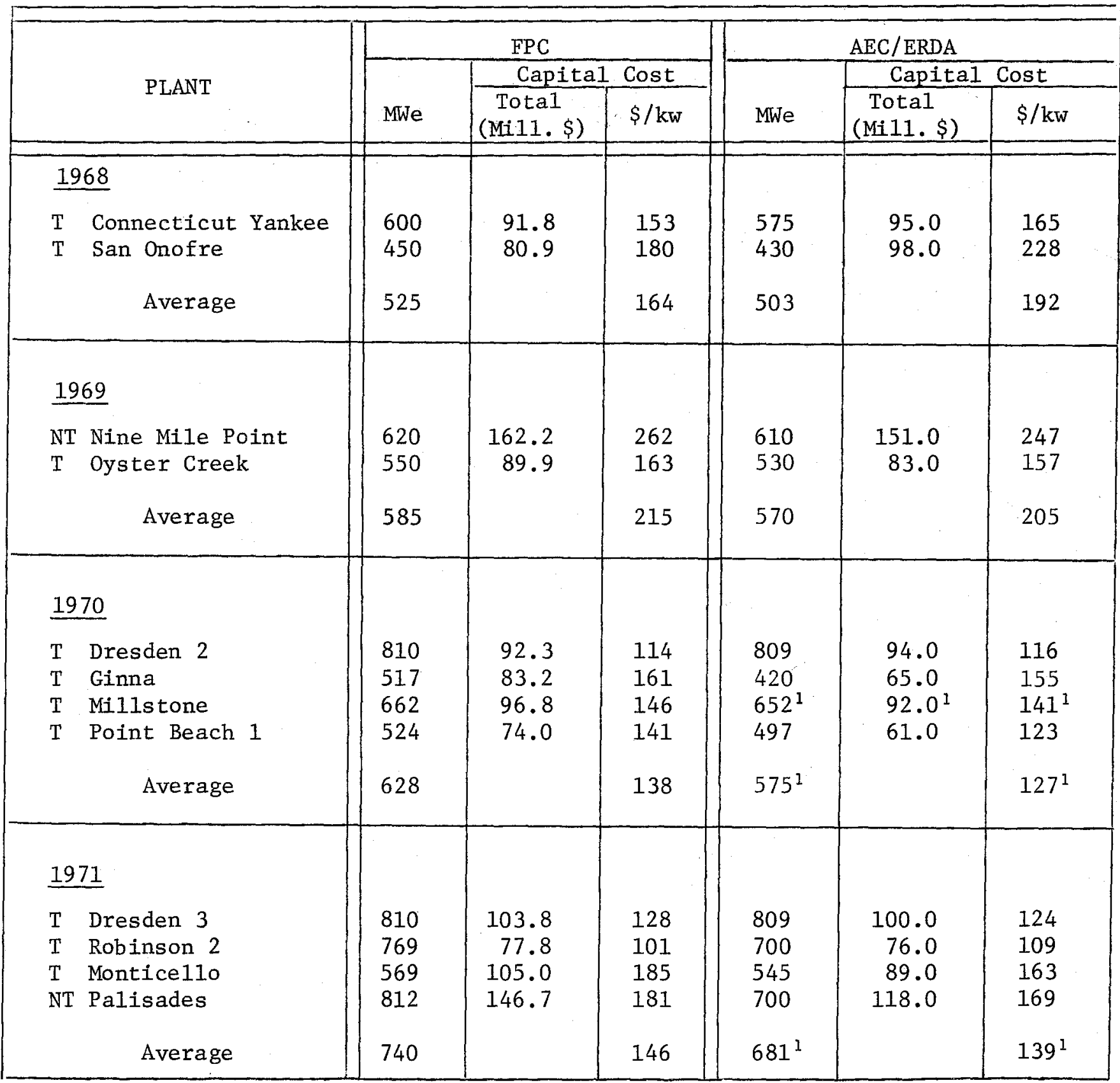


TABLE A-1

CAPITAL COSTS OF NUCLEAR UNITS

COMING ON LINE, 1968-1974

FPC AND AEC/ERDA

-CONTINUED-

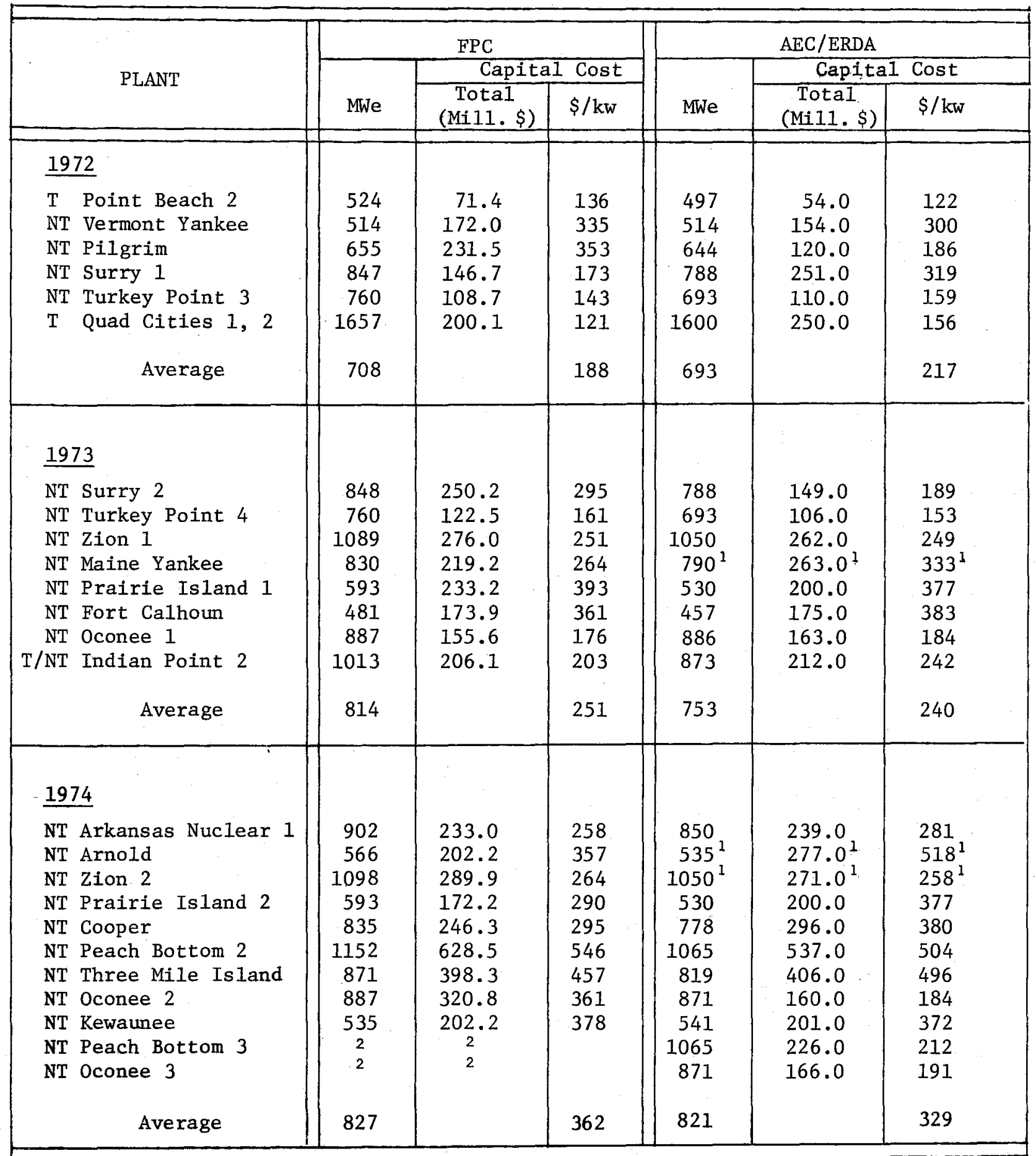

${ }^{1} \mathrm{Millstone}$ is classified as a 1971 unit by AEC, and appears in 1971 averages;

Zion 2 and Arnold are classified as 1975 units by AEC; Maine Yankee is classified as a 1972 unit by $A E C$, and appears in 1972 averages.

${ }^{2}$ Not shown in 1974 FPC.

$\mathrm{T}=$ turnkey, $\mathrm{NT}=$ nonturnkey. 
TABLE A-2

CAPITAL COST ESCALATION -- NUCLEAR PLANTS, 1967-1976

ESTIMATED CAPITAL COST \$/KWe $\triangle T$ SELECTED POINTS IN

TIME FOR ALL NUCLEAR PLANTS ORDERED 1965-1975

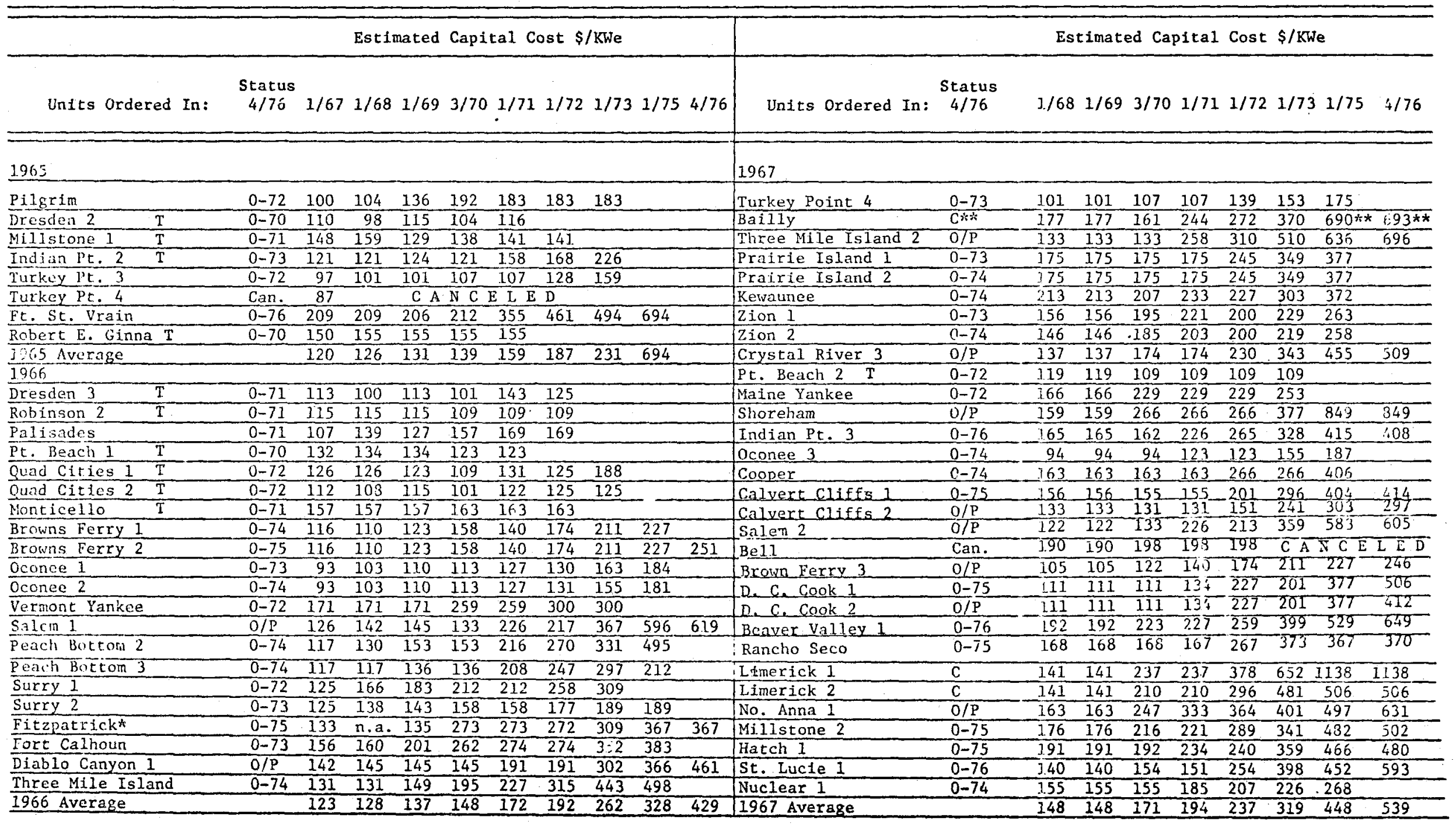

T refers to turnkey plant. 
TABLE A-2

(Continued)

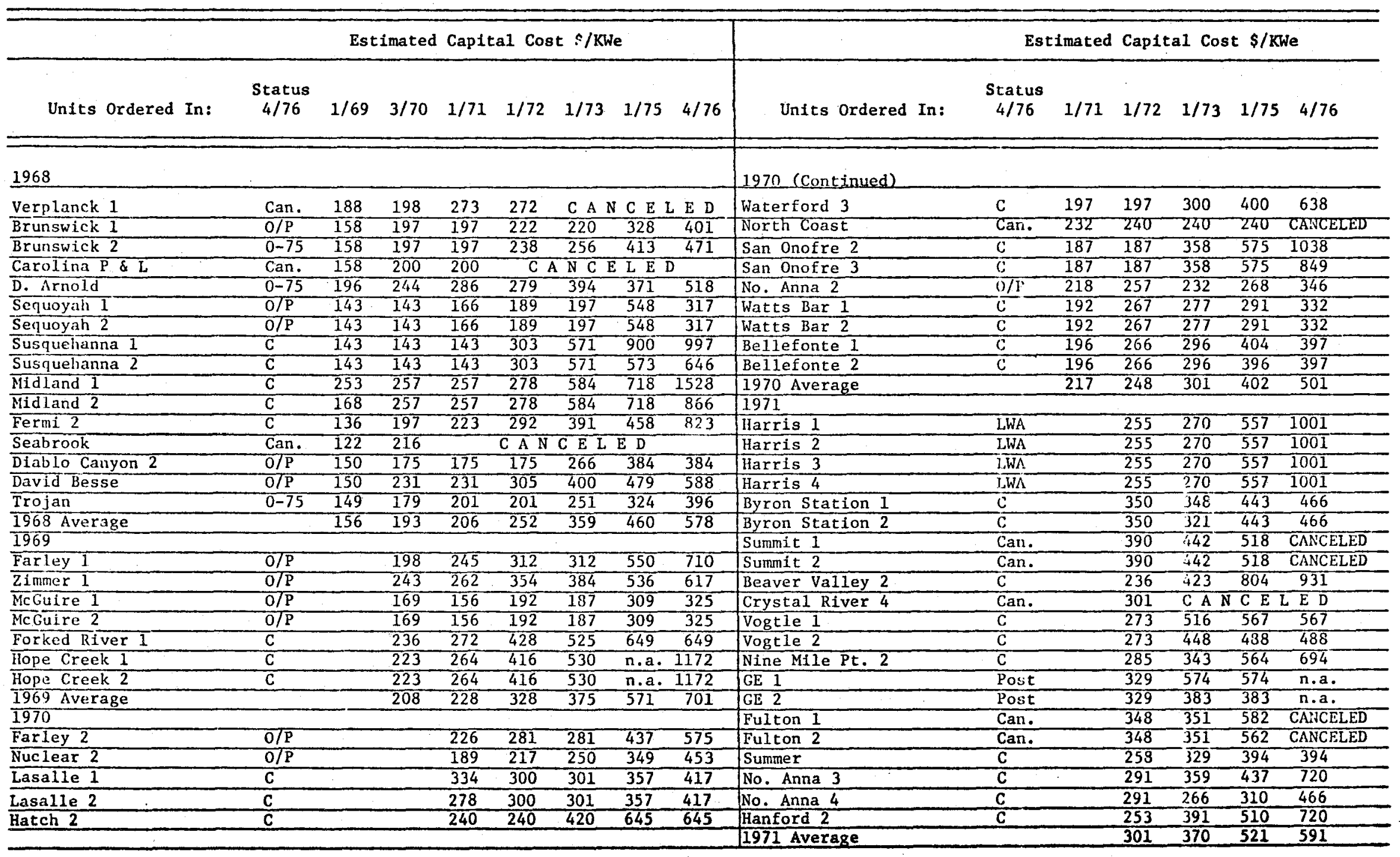


TABLE A-2

(Continued)

\begin{tabular}{|c|c|c|c|c|c|c|c|c|c|}
\hline & \multicolumn{4}{|c|}{ Estimated Cap1tal Cost \$/KWe } & & \multicolumn{4}{|c|}{ Estimated Capital Cost $\$ / \mathrm{KWe}$} \\
\hline Units Ordered In: & $\begin{array}{c}\text { Status } \\
4 / 76\end{array}$ & $1 / 73$ & $1 / 75$ & $4 / 76$ & Units Ordered In: & $\begin{array}{c}\text { Status } \\
4 / 76\end{array}$ & $1 / 73$ & $1 / 75$ & $4 / 76$ \\
\hline \multicolumn{5}{|l|}{1972} & \multicolumn{5}{|l|}{1972 (Continued) } \\
\hline Barton 1 & $\mathrm{C} / \mathrm{P}$ & 500 & 651 & 1271 & Douglas Pt. 1 & $\mathrm{C} / \mathrm{P}$ & 398 & 594 & 1002 \\
\hline Barton 2 & $\mathrm{C} / \mathrm{P}$ & 500 & 576 & 921 & Douglas $\mathrm{Pt} .2$ & $\mathrm{C} / \mathrm{P}$ & 398 & 594 & 781 \\
\hline Pilgrim 2 & $\mathrm{C} / \mathrm{P}$ & n.a. & 735 & 735 & Atlantic offshore 1 & $C / 1$ & 430 & 541 & 1087 \\
\hline Perry 1 & LWA & 409 & 512 & 642 & Atlantic offshore 2 & $C / P$ & 430 & 541 & 1087 \\
\hline Perry 2 & LWA & 409 & 512 & 642 & Seabrook 1 & $\mathrm{C} / \mathrm{P}$ & 386 & 507 & 507 \\
\hline Braidwood 1 & $\mathrm{C}$ & n.a. & 446 & 479 & Seabrook 2 & $\mathrm{C} / \mathrm{P}$ & 386 & 473 & 473 \\
\hline Braidwood 2 & $\mathrm{C}$ & n.a. & 446 & 479 & SCED/HTGR 1 & Can. & 606 & $\mathrm{CAN}$ & E L E D \\
\hline Quanicasse 1 & Can. & 522 & $\mathrm{CANO}$ & E LE D & SCED/HTGR 2 & Can. & 606 & $\mathrm{CAN}$ & ELED \\
\hline Quanicasse 2 & Can. & 522 & $\mathrm{CANC}$ & E I E D & Hartsville I & $\mathrm{C} / \mathrm{P}$ & 310 & 315 & 488 \\
\hline Fermi 3 & Can. & 410 & 6.05 & CANCELED & Hartsville 2 & $\mathrm{C} / \mathrm{P}$ & 310 & 315 & 488 \\
\hline Greenwood 2 & $\mathrm{C} / \mathrm{p}$ & 403 & 611 & 611 & Hartsville 3 & $C / T^{3}$ & 320 & 315 & 488 \\
\hline Greenwood 3 & $\mathrm{C} / \mathrm{P}$ & 403 & 611 & 611 & Hartsville 4 & $C / P$ & 320 & 315 & 483 \\
\hline Catawba 1 & C & 269 & 432 & 470 & Camanche Park 1 & $\mathrm{C}$ & 320 & 309 & 309 \\
\hline Catawba 2 & C & 269 & 432 & 470 & Camanche Park 2 & C & 320 & 309 & 309 \\
\hline St. Lucie 2 & LWA & 320 & 662 & 765 & Surry 3 & $\mathrm{C}$ & 325 & 511 & 1251 \\
\hline River Bend & LWA & 638 & 637 & 637 & Surry 4 & C & 325 & 375 & 891 \\
\hline Clinch River LMFBR & & 1748 & 4960 & 5571 & Nuclear Project 1 & $C$ & 473 & 530 & 942 \\
\hline \multirow{2}{*}{ Grand Gulf 1} & C & 515 & 525 & 560 & Grand GuIf 2 & C & 515 & 457 & 560 \\
\hline & & & & & 1972 Average & & 420 & 541 & 722 \\
\hline
\end{tabular}


TABLE A-2

(Continued)

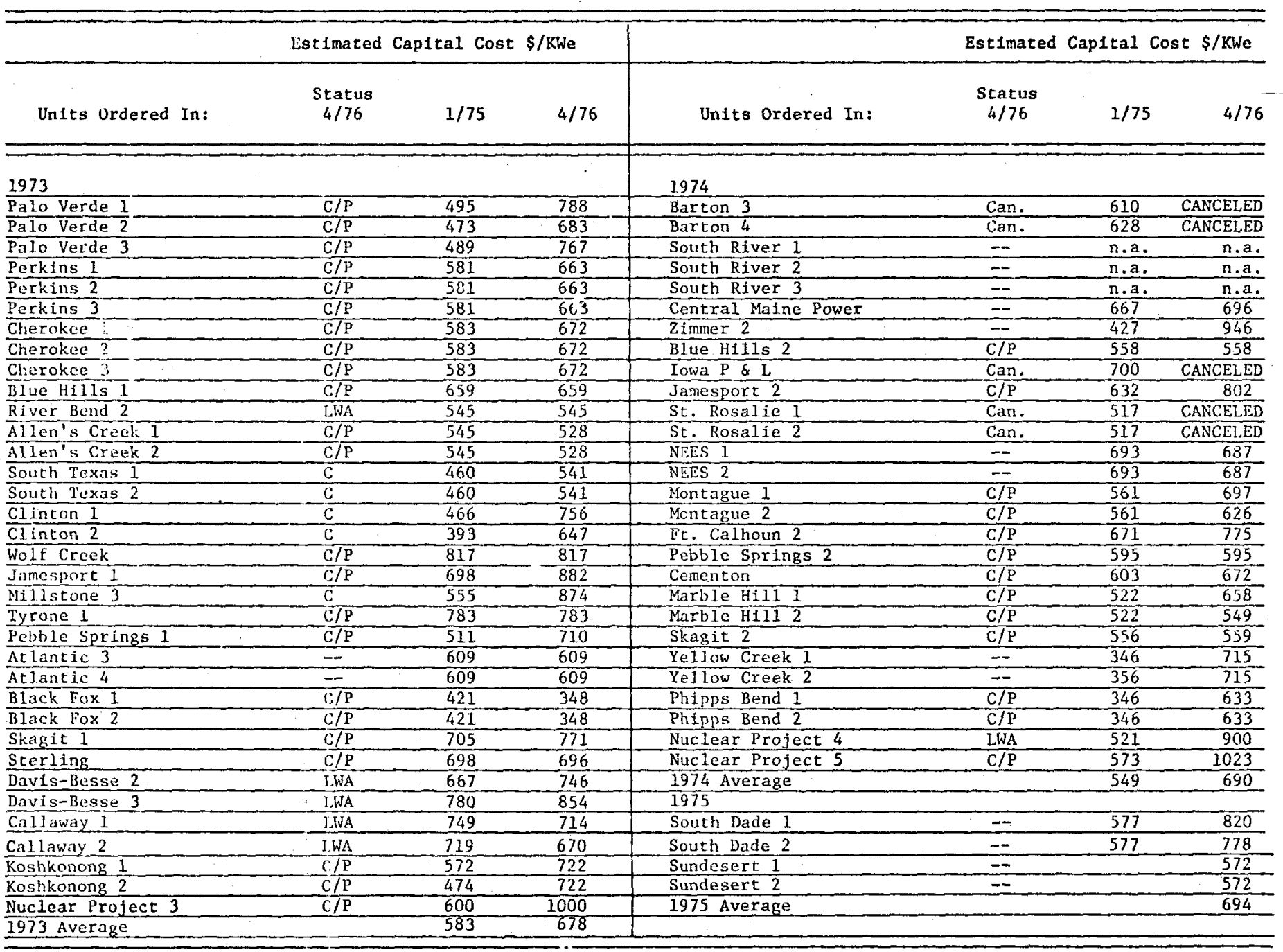

*Reclassified by AEC as a 1968 pilant in 1970.

**Construction halted under court order.

[Status 4/76: --, no application for construction permit; LWA -- 1imited work authorization while construction permit pending; C/P - construction permit pending; C - construction permit granted; O/P -- operating permit pending; 0 -- (date) -- operating permit granted, commercial operation of (date)].

Averages per year are average capital cost per KWe for plants not yet in commercial operation.

Source: "Central Station Nuclear Plants," ERDA, selected issues, 1968-1976. 
APPENDIX B

DELAYS IN THE ISSUANCE OF CP FOR UNITS APPLYING FOR CP, 1966-1970

A. Units Applying for CP in 1966

\begin{tabular}{|c|c|c|c|}
\hline Unit & $\begin{array}{l}\text { Time To } \\
\text { Obtain CP }\end{array}$ & Intervenors & Comments \\
\hline Fort St. Vrain & 23 & Yes & $\begin{array}{l}\text { First large gas cooled reactor. Delay due } \\
\text { to time required for staff and ACRS reports. }\end{array}$ \\
\hline Salem 1 & 21 & Yes & $\begin{array}{l}\text { Delay due to change in plant site after } \\
\text { initial application. }\end{array}$ \\
\hline Vermont Yankee & 13 & Yes & $\begin{array}{l}\text { Delay due in part ( } 4-5 \text { months) to intervenors } \\
\text { (environmental issues). }\end{array}$ \\
\hline Turkey Point 3, 4 & 13 & Yes & $\begin{array}{l}\text { Delay due to ACRS and staff reports. } \mathrm{CP} \\
\text { contains condition raised by intervenor. }\end{array}$ \\
\hline Oconee 1,2 & 12 & Yes & $\begin{array}{l}\text { Three months delay due to intervenor } \\
\text { ("practical value" issue). }\end{array}$ \\
\hline Point Beach 1 & 11 & Yes & No delay due to intervenor. \\
\hline Monticel1o & 10 & No & $\begin{array}{l}\text { First field erected pressure vessel; not a } \\
\text { source of delay }\end{array}$ \\
\hline Browns Ferry 1, 2 & 10 & No & $\begin{array}{l}\text { ACRS delays CP by two months -- diesel } \\
\text { generator system }\end{array}$ \\
\hline Palisades & 9 & No & No problems. \\
\hline Robinson 2 & 9 & No & No problems. \\
\hline Quad Cities 1 & 9 & No & $\begin{array}{l}\text { First case involving multiple units at one } \\
\text { site; not a source of delay }\end{array}$ \\
\hline Dresden 3 & 8 & No & $\begin{array}{l}\text { No problems. Identical to Dresden } 2 \text {, already } \\
\text { under construction. }\end{array}$ \\
\hline Quad Cities 2 & 6 & No & See Quad Cities 1. \\
\hline
\end{tabular}


B. Units Applying for CP in 1967

\begin{tabular}{|c|c|c|c|}
\hline Unit & $\begin{array}{l}\text { Time To } \\
\text { Obtain CP }\end{array}$ & Intervenors & Comments \\
\hline Indian Point 3 & 28 & Yes & $\begin{array}{l}22 \text { months from application to notice of } \\
\text { hearing. Safety issues raised by intervenors. } \\
\text { Appeals, CP affirmed. }\end{array}$ \\
\hline $\begin{array}{l}\text { Zion } 1 \\
\text { Zion } 2\end{array}$ & $\begin{array}{l}17 \\
16\end{array}$ & $\begin{array}{l}\text { No } \\
\text { No }\end{array}$ & $\begin{array}{l}\text { ACRS concern with population density; staff-LB } \\
\text { differences on safety issues, ownership of } \\
\text { Commonwealth Edison. Appeal on ownership issue, } \\
\text { CP affirmed by AEC. }\end{array}$ \\
\hline Surry 1,2 & 15 & No & $\begin{array}{l}13 \text { months from application to notice of hearing. } \\
\text { No problems. }\end{array}$ \\
\hline Diablo Canyon & 15 & Yes & $\begin{array}{l}\text { Seismicity issue raised; no problems due to } \\
\text { intervenors }\end{array}$ \\
\hline Prairie Island 1,2 & 15 & Yes & $\begin{array}{l}\text { Safety issues raised; no delays due to } \\
\text { intervenor (application changed from } 1 \text { to } 2 \\
\text { units). }\end{array}$ \\
\hline Cook 1, 2 & 15 & No & $\begin{array}{l}\text { No apparent problems }-12 \text { months for ACRS, } \\
\text { staff reports. }\end{array}$ \\
\hline Pilgrim & 14 & Yes & $\begin{array}{l}\text { "Practical value" intervenors - some accepted, } \\
\text { some denied standing. Appeals, denied }\end{array}$ \\
\hline Fort Calhoun & 14 & No & $\begin{array}{l}\text { Staff-LB differences. CP is conditioned. } \\
\text { AEC later rejects conditions. }\end{array}$ \\
\hline Crystal River & 13 & Yes & $\begin{array}{l}\text { "Practical value" raised. CP is conditioned, } \\
\text { but no apparent delays due to intervenors. } \\
\text { Appealed, CP affirmed }\end{array}$ \\
\hline Maine Yankee & 13 & No & $\begin{array}{l}\text { "Practical value" intervenors denied standing. } \\
\text { Problem with financial qualifications of } \\
\text { applicant, OK'd two years later. }\end{array}$ \\
\hline Ark. Nuclear 1 & 13 & No & Uncontested. No problems. \\
\hline 3 Mile Island & 12 & Yes & $\begin{array}{l}\text { Uncontested. Proximity to airport a minor } \\
\text { problem. }\end{array}$ \\
\hline Kewaunee & 12 & Yes & Uncontested. No problems. \\
\hline Point Beach 2 & 12 & Yes & Uncontested. No problems \\
\hline Browns Ferry 3 & 12 & No & No problem. \\
\hline Peach Bottom 2, 3 & 11 & Yes & $\begin{array}{l}\text { "Practical value" intervenors, no delay. } \\
\text { Appealed, CP affirmed. }\end{array}$ \\
\hline Cooper & 11 & No & $\begin{array}{l}\text { Several amendments filed prior to hearing, but } \\
\text { no delay problems with them. }\end{array}$ \\
\hline
\end{tabular}


APPENDIX B

(Continued)

B. Units Applying for CP in 1967

(Continued)

\begin{tabular}{l|c|c|c|c}
\hline \multicolumn{1}{c|}{ Unit } & $\begin{array}{c}\text { Time To } \\
\text { Obtain CP }\end{array}$ & Intervenors & Comments \\
\hline Rancho Seco & 11 & No & $\begin{array}{l}\text { LB notes that if there had been intervenor, } \\
\text { more complete staff study would have been needed. }\end{array}$ \\
\hline Salem 2 & 11 & Yes & $\begin{array}{l}\text { Intervenor issues related to ol not CP. } \\
\text { No problems. }\end{array}$ \\
\hline Oconee 3 & 7 & Yes & $\begin{array}{l}\text { "Practical value intervenors denied standing. } \\
\text { Various appeals, all denied. }\end{array}$ \\
\hline
\end{tabular}

C. Units Applying for CP in 1968

\begin{tabular}{|c|c|c|c|}
\hline Unit & $\begin{array}{c}\text { Time To } \\
\text { Obtain CP }\end{array}$ & Intervenors & Comments \\
\hline Shoreham & 59 & Yes & $\begin{array}{l}\text { Intervenor objects to ASLB's application of 'NEPA, } \\
\text { raises bias issue, claims work being done without } \\
\mathrm{CP} \text {, raises freedom of information issues, various } \\
\text { appeals to ASLAB, all rejected. Length of time } \\
\text { related to NEPA FES requirements. }\end{array}$ \\
\hline Diablo Canyon 2 & 30 & Yes & $\begin{array}{l}17 \text { months from CP application to notice of } \\
\text { hearing. Delays in hearings due to seismic } \\
\text { issues. NEPA issues raised by intervenors. } \\
\text { Appealed, CP affirmed even though by time of } \\
\text { AB decision, procedures have changed. On second } \\
\text { appeal (1973) results in conditions on CP, } \\
\text { several issues raised by intervenor, suspension } \\
\text { of some construction. }\end{array}$ \\
\hline 3 Mile Island 2 & 19 & No & $\begin{array}{l}\text { Uncontested. } 16 \text { months from CP application to } \\
\text { notice of hearing. }\end{array}$ \\
\hline Brunswick 1, 2 & 19 & No & $\begin{array}{l}\text { "Practical value" intervention denied. Appeal, } \\
\text { denial (at CP stage) affirmed. (five month } \\
\text { suspension of construction for NEPA reasons } \\
\text { occurs from } 11 / 71-4 / 72 \text { ). }\end{array}$ \\
\hline Arnold 1 & 19 & Yes & $\begin{array}{l}3 \text { month delay relating to financial qualifica- } \\
\text { tions of applicant; involved a dispute with REA. } \\
\text { Reviewed and affirmed by } A B \text {. }\end{array}$ \\
\hline
\end{tabular}


APPENDIX B

(Continued)

C. Units Applying for CP in 1968

(Continued)

\begin{tabular}{l|c|c|c|c}
\hline Unit & $\begin{array}{c}\text { Time To } \\
\text { Obtain CP }\end{array}$ & Intervenors & Comments \\
\hline Sequoyah 1,2 & 19 & No & $\begin{array}{l}15 \text { months for staff safety evaluation. } \\
\text { Uncontested. First CP since NEPA passed, } \\
\text { No major de1ays due to NEPA. }\end{array}$ \\
\hline Calvert Cliffs 1,2 & 18 & Yes & $\begin{array}{l}\text { Safety issues raised by intervenors rejected. } \\
\text { Appealed, CP affirmed by AEC. } \\
\text { court case occurs after CP issuance.) }\end{array}$ \\
\hline Fitzpatrick 1 & 17 & No & $\begin{array}{l}\text { No problems, except coordination with state } \\
\text { agency regarding releases into Lake Ontario. }\end{array}$ \\
\hline Hatch 1 & 16 & No & Uncontested. No problems. \\
\hline
\end{tabular}

D. Units Applying for CP in 1969

\begin{tabular}{|c|c|c|c|}
\hline Unit & $\begin{array}{c}\text { Time To } \\
\text { Obtain CP }\end{array}$ & Intervenors & Comments \\
\hline Midland 1, 2 & 47 & Yes & $\begin{array}{l}\text { Safety issues raised by intervenor, led into } \\
\text { freedom of information appeals, rejected by } A B \text {, } \\
\text { claim construction occurring before } C P \text { issuance } \\
\text { rejected by } A B \text {, also rejected by } A E C \text {, various } \\
\text { other motions denied by } A B \text {. Delays apparently } \\
\text { due to intervenors. CP appealed, affirmed. } \\
\text { Bias of LB claimed, denied. Petition to } \\
\text { strengthen quality assurance during construction } \\
\text { denied. }\end{array}$ \\
\hline Fermi 2 & 41 & No & $\begin{array}{l}\text { Uncontested. } 24 \text { months from } \mathrm{CP} \text { application to } \\
\text { notice of hearing. Reviewed by } \mathrm{AB} \text { because of } \\
\text { discrepancies between staff and } \mathrm{LB} \text { on "as low as } \\
\text { practicable" calculations. CP affirmed after } \\
\text { lecture to LB on resolving such issues at } \mathrm{CP} \\
\text { hearing. }\end{array}$ \\
\hline Farley 1 & $34^{\circ}$ & Yes & $\begin{array}{l}\text { First case involving an environmental hearing } \\
\text { pursuant to NEPA, Calvert Cliffs decision. } 21 \\
\text { months from CP application to notice of hearing. } \\
\text { Intervenors raised need for power and environ- } \\
\text { mental issues. All rejected, monitoring of } \\
\text { weather and noise data required of applicant. } \\
\text { No appeals. }\end{array}$ \\
\hline
\end{tabular}




\begin{tabular}{|c|c|c|c|}
\hline Unit & $\begin{array}{c}\text { Time To } \\
\text { Obtain CP }\end{array}$ & Intervenors & Comments \\
\hline North Anna 1, 2 & 23 & Yes & $\begin{array}{l}\text { Environmental issues raised, dismissed as } \\
\text { beyond AEC scope. CP later conditioned to } \\
\text { meet NEPA conditions. }\end{array}$ \\
\hline Millstone 2 & 20 & Yes & $\begin{array}{l}\mathrm{CP} \text { issued with condition requiring compliance } \\
\text { with state and federal environmental standards. } \\
\text { Environmental issues raised by intervenors are } \\
\text { rejected. Appealed, } \mathrm{CP} \text { affirmed by } \mathrm{AB} \text {. }\end{array}$ \\
\hline Davis Besse 1 & 20 & Yes & $\begin{array}{l}\text { "Practical value" intervenors denied standing. } \\
\text { Appeal, affirmed. Bias issue raised, rejected } \\
\text { by AEC, safety issues, environmental issues, } \\
\text { meteorological issues raised and rejected. } \\
\text { Appeal, CP affirmed. Stay of construction } \\
\text { petition denied by AB. } 4 / 72 \text {, court orders } \\
\text { hearing on stay for NEPA review. Hearing held, } \\
\text { stay again denied. Appealed to AEC, again } \\
\text { stay denied. }\end{array}$ \\
\hline Trojan & 20 & Yes & $\begin{array}{l}\text { Environmental issues and "as low as practicable' } \\
\text { safety issues raised by intervenors. } 14 \text { months } \\
\text { from CP application to notice of hearing. LB } \\
\text { rejects intervenor contentions. Appealed, CP } \\
\text { affirmed. } 4 / 72 \text {, petition for stay of construc- } \\
\text { tion for NEPA review. Intervenors and applicant } \\
\text { reach agreement before hearing on petition. No } \\
\text { stay of construction. }\end{array}$ \\
\hline St Lucie 1 & 18 & Yes & $\begin{array}{l}\text { Compromise with one intervenor on use of river } \\
\text { water before hearing, intervenor withdraws. } \\
\text { State of Florida accepts an agreement to obey } \\
\text { environmental laws of the state. Staff appeals } \\
\text { on the basis of the language of this condition. } \\
A B \text { accepts staff recommendation. }\end{array}$ \\
\hline Beaver Valley 1 & 17 & Yes & $\begin{array}{l}\text { Uncontested decision. } 16 \text { months CP application } \\
\text { to prehearing conference. Only problem is staff } \\
\text { recommendation for second containment structure. }\end{array}$ \\
\hline
\end{tabular}


APPENDIX B

(Continued)

E. Units Applying for CP in 1970

\begin{tabular}{|c|c|c|c|}
\hline Unit & $\begin{array}{l}\text { Time To } \\
\text { Obtain CP }\end{array}$ & Intervenors & Comments \\
\hline Northcoast Power & - & - & Withdrew after CP application. \\
\hline Hope Creek 1, 2 & 57 & Yes & $\begin{array}{l}21 \text { months from CP application to establishment } \\
\text { of LB. Site changed during CP process. New } \\
\text { LB appointed } 47 \text { months after CP application. } \\
\text { Intervenors withdraw before CP hearing on basis } \\
\text { of agreement with applicant. }\end{array}$ \\
\hline Limerick 1,2 & 51 & Yes & $\begin{array}{l}21 \text { months from CP application to notice of hear- } \\
\text { ing. Delay of licensing for } 13 \text { months due to } \\
\text { environmental hearing. Intervenor raised safety } \\
\text { issues, seismic, quality assurance, water supply. } \\
\text { CP conditioned to require EIS on water reservoir. }\end{array}$ \\
\hline Waterford 3 & 47 & Yes & $\begin{array}{l}\text { "Practical value" intervention permitted. } \\
\text { Procedural delays associated with individual } \\
\text { intervenor. Anti-trust a major issue. Safety } \\
\text { and environmental issues raised at } \mathrm{CP} \text { hearing, } \\
\text { intervenor items rejected by } \mathrm{LB} \text {. CP includes } \\
\text { conditions relating to anti-trust issues. } \\
\text { Reviewed by } \mathrm{AB} \text { and affirmed. }\end{array}$ \\
\hline Bailly & 45 & Yes & $\begin{array}{l}13 \text { months from } \mathrm{CP} \text { application to establishment } \\
\text { of } \mathrm{ASLB} \text {. Issues raised by intervenors, appealed } \\
\text { to } \mathrm{AB} \text { and } \mathrm{AEC} \text { and rejected, including intimida- } \\
\text { tion of one of intervenors witnesses, bias, } \\
\text { quorum problems, freedom of information, new } \\
\text { evidence. Intervenors obtain temporary stay } \\
\text { of } \mathrm{CP} \text {, condition on } \mathrm{CP} \text {. Case taken to circuit } \\
\text { court. CP reopened } 10 / 74 \text { because of court } \\
\text { decision. No substantive changes in CP. }\end{array}$ \\
\hline San Onofre 2,3 & 41 & Yes & $\begin{array}{l}\text { Several prehearings and hearings ( } 8 \text { months } \\
\text { between first prehearing and final hearing). } \\
\text { Safety, seismic issues raised. LB rules } \\
\text { underground siting not feasible as a } \\
\text { practical alternative. CP issued with several } \\
\text { conditions. Later, } 1 / 74 \text {, California Coastal } \\
\text { Commission bans construction; } 2 / 20 / 74 \text {, } \\
\text { construction permitted subject to conditions. } \\
\text { AB rejects intervenor petition that AEC continue } \\
\text { California ban on construction. }\end{array}$ \\
\hline
\end{tabular}


APPENDIX B

(Continued)

E. Units Applying for $\mathrm{CP}$ in 1970

(Continued)

\begin{tabular}{|c|c|c|c|}
\hline Unit & $\begin{array}{l}\text { Time To } \\
\text { Obtain CP }\end{array}$ & Intervenors & Comments \\
\hline Forked River 1 & 37 & Yes & $\begin{array}{l}\text { Uncontested. } 26 \text { months from CP application to } \\
\text { establishment of ASLB. New Jersey wants a } \\
\text { condition in CP making New Jersey air pollution } \\
\text { code binding. Rejected by LB. }\end{array}$ \\
\hline LaSa11e 1, 2 & 34 & Yes & $\begin{array}{l}\text { Environmental issues; } L B \text { includes monitoring } \\
\text { requirements in } C P \text {. AB and } A E C \text { review the } C P \\
\text { decision, find quality assurance problems. } \\
\text { Applicant changes } Q A \text { organization so that no } \\
\text { stays or further conditions imposed on } C P \text {. } \\
\text { Applicant succeeds (at } A B \text { level) in disqualify- } \\
\text { ing one member of } L B \text {. }\end{array}$ \\
\hline Zimmer 1 & 29 & No & $\begin{array}{l}\text { Uncontested. } 23 \text { months from } C P \text { application to } \\
\text { notice of hearing. AB remands the case because } \\
\text { of inadequate record relative to cooling tower, } \\
\text { no stay of construction. LB heard additional tes- } \\
\text { timony and recommended no change. AB affirms CP. }\end{array}$ \\
\hline McGuire 1,2 & 29 & Yes & $\begin{array}{l}\text { "Practical value intervenors denied standing. } \\
233 \text { items introduced by remaining intervenors; } \\
\text { a11 are rejected by staff and LB. }\end{array}$ \\
\hline Hatch 2 & 29 & No & $\begin{array}{l}\text { Uncontested. } 24 \text { months from CP application to } \\
\text { notice of hearing. Essentially identical to Unit } \\
1 \text { under construction. } 16 \text { amendments to PSAR } \\
\text { during staff review. Monitoring requirements } \\
\text { included as condition of CP. No appeals. }\end{array}$ \\
\hline Ark. Nuclear 2 & 27 & No & $\begin{array}{l}\text { Uncontested. Staff appeals condition attached } \\
\text { to } \mathrm{CP} \text {. AB affirms LB's condition. }\end{array}$ \\
\hline Farley 2 & 26 & Yes & $\begin{array}{l}\text { "Practical value" and environmental issues. } \\
\text { Exemption granted by LB to begin construction } \\
16 \text { months before CP issued. }\end{array}$ \\
\hline
\end{tabular}


SUSPENDED OR CANCELED NUCLEAR POWER PLANTS BETWEEN 1970-1977 WITH OUTSTANDING NSSS ORDER

\begin{tabular}{|c|c|c|c|c|}
\hline $\begin{array}{c}\text { Year of } \\
\text { Suspension } \\
\text { or } \\
\text { Cancellation }\end{array}$ & Name & Owner & $\begin{array}{l}\text { Reactor } \\
\text { Supplier }\end{array}$ & $\begin{array}{c}\text { Year of } \\
\text { NSSS } \\
\text { Order }\end{array}$ \\
\hline (1) 1970 & MaIibu & LADWP & $W$ & 63 \\
\hline (1) 1971 & Unit 4 & Carolina $\mathrm{P} \& \mathrm{~L}$ & $\mathrm{GE}$ & 68 \\
\hline \multirow[t]{4}{*}{ (5) 1972} & Be11 & NYSGE & GE & 67 \\
\hline & Verplanck $1 \& 2$ & Consolidated Edison & $\overline{\mathrm{GE}}$ & $68 \& 69$ \\
\hline & Waterford 4 & Louisiana $\mathrm{P} \& \mathrm{~L}$ & $W$ & 70 \\
\hline & Crystal River 4 & Florida Power & & 71 \\
\hline \multirow[t]{3}{*}{ (5) 1973} & Aguirre & PRWRA & $\mathrm{W}$ & 70 \\
\hline & Mendocino $1 \& 2$ & $P G \& E$ & GE & 71 \\
\hline & Perryman $1 \& 2$ & Baltimore Electric & Comb. & 72 \\
\hline \multirow[t]{7}{*}{ (11) 1974} & Vogtle $\quad 1 \& 2$ & Georgia Power & $W$ & 71 \\
\hline & Quanicasse $1 \& 2$ & Consolidated Power & $\vec{W}$ & 72 \\
\hline & Vidal $\quad 1 \& 2$ & $\mathrm{SCE}$ & $\mathrm{GA}$ & 72 \\
\hline & Fermi 3 & Detroit & GE & 72 \\
\hline & Tyrone 2 & Northern States Power. & $W$ & 73 \\
\hline & Boardman & Portland & $\mathrm{B} \& \mathrm{~W}$ & 73 \\
\hline & Off Shore $1 \& 2$ & Jacksonville E.A. & OPS & 74 \\
\hline \multirow[t]{3}{*}{ (6) 1975} & Fulton $\quad 1 \& 2$ & Philadelphia Electric & $\mathrm{GA}$ & 71 \\
\hline & Allens Creek $1 \& 2$ & Houston Iight and Power & GE & 73 \\
\hline & St. Rosalie $1 \& 2$ & Louisiana & GA & 74 \\
\hline \multirow[t]{6}{*}{$(10) 1976$} & Summit $1 \& 2$ & Delmarva & GA & 71 \\
\hline & Barton $1 \& 2$ & Alabama & $\mathrm{GE}$ & 72 \\
\hline & Barton $3 \& 4$ & Alabama & GE & 74 \\
\hline & NORCO-NP-1 & PRWRA & $W$ & 74 \\
\hline & Unit $2 \& 3$ & Florida Power & Comb. & 74 \\
\hline & Iowa Power and Light & & GE & 74 \\
\hline \multirow[t]{5}{*}{ (8) 1977} & Douglas Point & Potamac Electric Power & $\mathrm{GE}$ & 72 \\
\hline & Surry $3 \& 4$ & Virginia Electric Power & $B \& W$ & 72 \\
\hline & Sears Island & Centra1 Maine & $W$ & 74 \\
\hline & South Dade $1 \& 2$ & Florida $\mathrm{P} \& \mathrm{~L}$ & $W$ & 75 \\
\hline & Vandalia & Iowa Power & $B \& W$ & 76 \\
\hline
\end{tabular}

Source: Electrical World, 1965-1977, U.S. Central Station Nuclear Electrical Generation Units: Significant Milestones, $1965-1977$.

Tables in this appendix were prepared by Katsuaki Terasawa, Jet Propulsion Laboratory. 
DELAYS IN EXPECTED COMMERCIAL OPERATION DATE

BETWEEN 1970-1977

\begin{tabular}{|c|c|c|c|c|c|c|c|c|c|c|c|c|}
\hline \multirow{2}{*}{$\begin{array}{l}\text { Year of } \\
\text { NSSS } \\
\text { Order }\end{array}$} & \multirow{2}{*}{$\begin{array}{l}\text { Number } \\
\text { of } \\
\text { Order }\end{array}$} & \multicolumn{7}{|c|}{ Average Delay In } & \multirow{2}{*}{$\begin{array}{c}\text { Ranges in } \\
\text { Annual } \\
\text { Delays }\end{array}$} & \multirow{2}{*}{$\begin{array}{l}\text { Number of } \\
\text { Plants } \\
\text { Suspended } \\
\text { or } \\
\text { Canceled }\end{array}$} & \multicolumn{2}{|c|}{$\begin{array}{l}\text { Average Length } \\
\text { (Yrs.) of Approval } \\
\text { Since NSSS Order }\end{array}$} \\
\hline & & $70-71$ & $71-72$ & $72-73$ & $73-74$ & $74-75$ & $75-76$ & $76-77$ & & & $\mathrm{CP}$ & $\underline{\mathrm{OL}}$ \\
\hline 65 & 7 & .6 & .5 & 1.0 & & 1.0 & 2.0 & & $0-5$ & 0 & 1.5 & 6 \\
\hline 66 & 21 & .6 & .8 & .4 & .5 & .3 & .5 & .5 & $0-5$ & 1 & 1.5 & 6 \\
\hline 67 & 31 & .4 & .7 & .5 & .7 & .6 & .8 & 0 & $0-8$ & 1 & 2.5 & 8 \\
\hline 68 & 16 & 1.0 & .4 & .5 & .6 & .9 & .5 & 0 & $1-8$ & 2 & 3.0 & \\
\hline 69 & 8 & .4 & .9 & 1.0 & .8 & .9 & 1.0 & .1 & $2-9$ & 1 & 3.5 & \\
\hline 70 & 15 & .3 & 1.0 & .5 & .5 & .7 & .5 & .1 & $2-7$ & 2 & 3.5 & \\
\hline 71 & 21 & & .3 & .5 & 1.6 & 1.9 & .7 & .4 & $3-11$ & 9 & 4.0 & \\
\hline 72 & 38 & & & .2 & 1.0 & 1.1 & .7 & .5 & $1-8$ & 13 & & \\
\hline 73 & 37 & & & & .9 & .7 & .8 & .8 & $1-8$ & 4 & & \\
\hline 74 & 33 & & & & 1.8 & 1.0 & 1.2 & .1 & $1-9$ & 11 & & \\
\hline 75 & 4 & & & & & & -1.5 & .5 & $(1)-1$ & 2 & & \\
\hline 76 & 3 & & & & & & & 2.0 & $0-2$ & 1 & & \\
\hline 77 & & & & & & & & & & & & \\
\hline
\end{tabular}

Source: Electrical Wor1d, 1965-1977, U.S. Central Station Nuciear Electrical Generation Units: Significant Milestones, $1965-1977$.

Note: For each year entries to the left of the solid line reflect delays in $\mathrm{CP}$. Entries to the right of the broken line indicate delays after $\mathrm{OL}$ has been issued. The entries bordered by the broken and solid line reflect delays after CP is issued but prior to OL Issuance. 


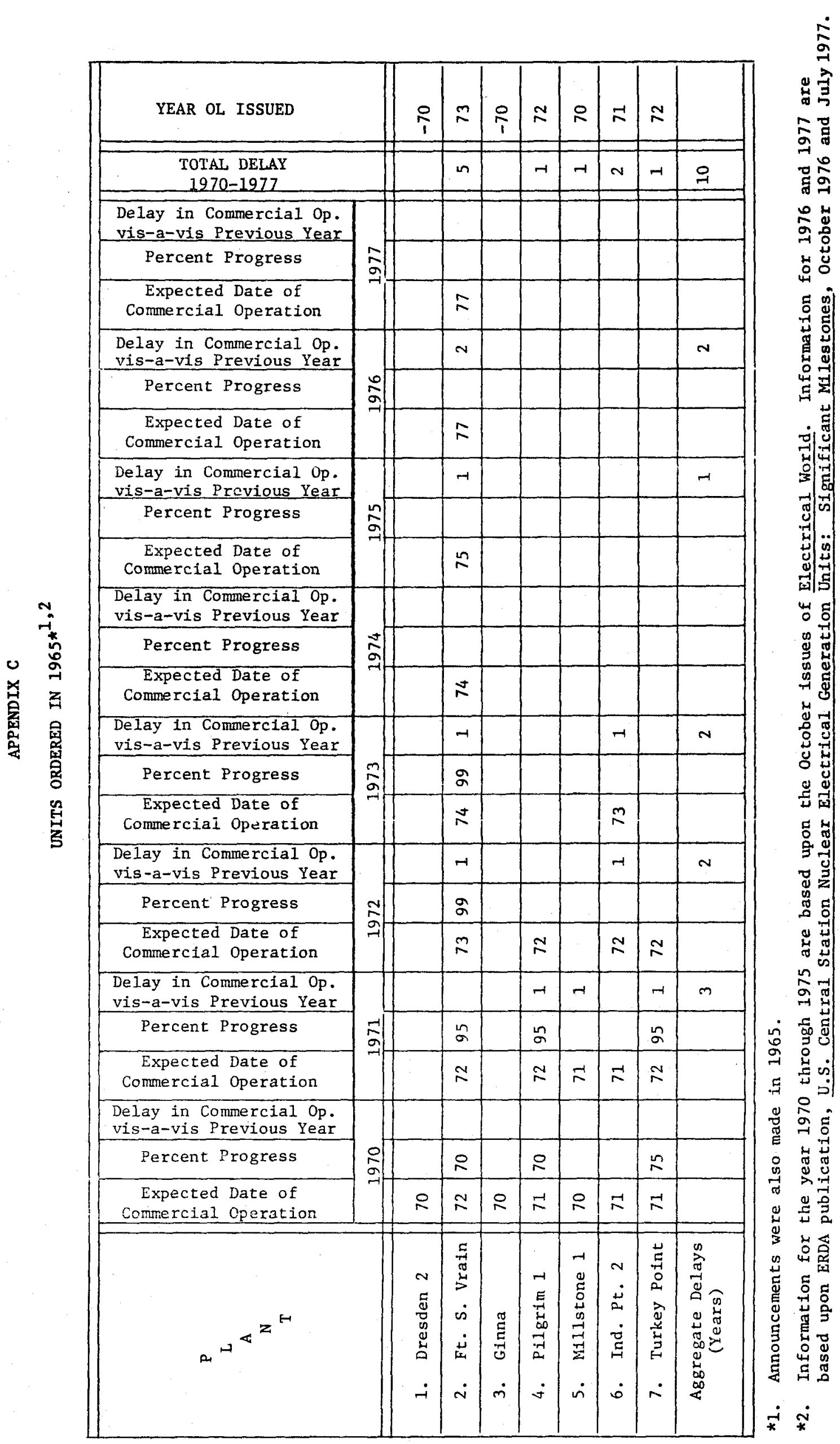


UNITS ORDERED IN 1966

\begin{tabular}{|c|c|c|c|c|c|c|c|c|c|c|c|c|c|c|c|c|c|c|c|c|c|c|c|c|c|c|}
\hline \multirow[t]{2}{*}{$\stackrel{\mathrm{P}}{\mathrm{L}} \underset{\mathrm{A}}{\mathrm{N}} \mathrm{T}$} & 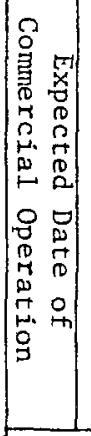 & 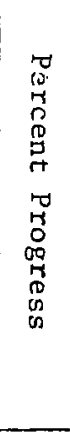 & 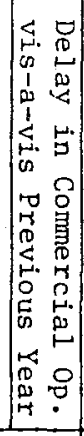 & 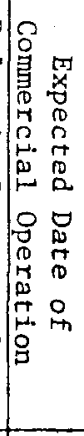 & 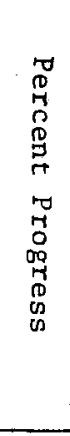 & 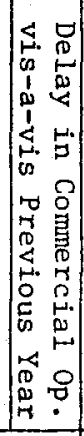 & 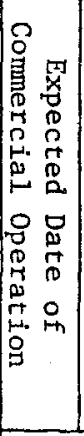 & 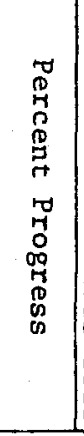 & 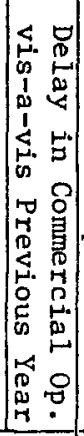 & 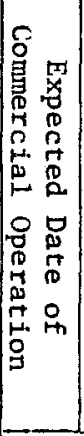 & 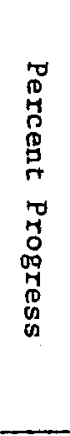 & 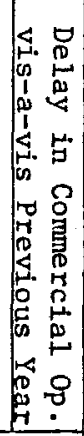 & 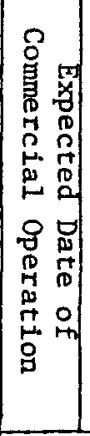 & $\begin{array}{l}0 \\
0 \\
0 \\
0 \\
0 \\
0 \\
0 \\
7 \\
0 \\
0 \\
0 \\
0 \\
0 \\
0 \\
0 \\
0 \\
0\end{array}$ & 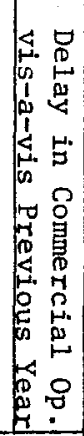 & 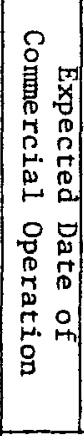 & $\begin{array}{l}1 \\
0 \\
0 \\
0 \\
0 \\
0 \\
0 \\
0 \\
0 \\
0 \\
0 \\
0 \\
0 \\
0 \\
0 \\
0 \\
0 \\
\\
\end{array}$ & 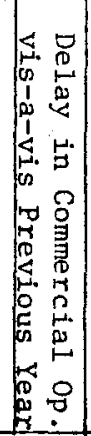 & 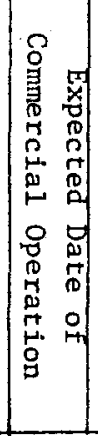 & $\begin{array}{l}0 \\
0 \\
0 \\
0 \\
0 \\
0 \\
7 \\
0 \\
0 \\
0 \\
00 \\
0 \\
0 \\
0 \\
0 \\
0 \\
\end{array}$ & 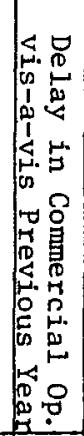 & 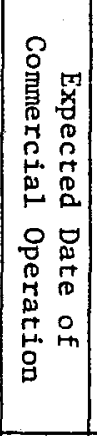 & $\begin{array}{c}0 \\
0 \\
0 \\
0 \\
0 \\
0 \\
0 \\
0 \\
0 \\
0 \\
0 \\
0 \\
0 \\
0 \\
0 \\
0\end{array}$ & 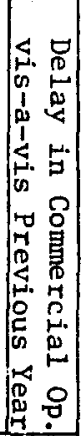 & 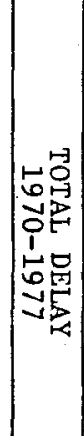 & 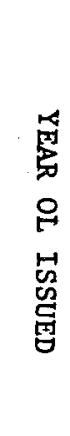 \\
\hline & \multicolumn{3}{|c|}{1970} & \multicolumn{3}{|c|}{1971} & \multicolumn{3}{|c|}{1972} & \multicolumn{3}{|c|}{1973} & \multicolumn{3}{|c|}{1974} & \multicolumn{3}{|c|}{1975} & \multicolumn{3}{|c|}{1976} & \multicolumn{3}{|c|}{1977} & & \\
\hline Dresden 3 & 70 & 75 & & 71 & & 1 & & & & & & & & & & & & & & & & & & & 1 & 71 \\
\hline 2. Palisades & 71 & & & 71 & & & & & & & & & & & & & & & & & & & & & & 71 \\
\hline Robinson 2 & 70 & & & 71 & & 1 & & & & & & & & 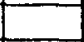 & & & & & & 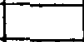 & & & & & 1 & 70 \\
\hline 4. Point Beach 1 & 70 & . & & & & & & & & & & & & & & & & & & & & & & & & 70 \\
\hline Monticello & 70 & & & 71 & & 1 & & & & & & & & & & & & & & & & & & & 1 & 70 \\
\hline 6. Quad Cities & 71 & 80 & & & & & 73 & & 2 & & & & & & & & & & & & & & & & 2 & 71 \\
\hline Browns Fer. 1 & 71 & 70 & & 72 & 90 & 1 & 73 & 98 & 1 & 73 & 99 & & 74 & & 1 & & & & & - & & & & & 3 & 73 \\
\hline 8. Browns Fer. 2 & 72 & 50 & & 73 & 70 & 1 & 74 & 70 & 1 & 74 & 80 & & 74 & 99 & & 75 & & 1 & & & & & & & 3 & 74 \\
\hline Oconee 1 & 71 & 70 & & 71 & .99 & & 73 & 99 & 2 & 73 & & & & & & & & & & & & & & & 2 & 73 \\
\hline Oconee 2 & 72 & 40 & & 72 & 70 & & 73 & 80 & 1 & 73 & 99 & & 74 & & 1 & & & & & & & & & & 2 & 73 \\
\hline Quad Cities 2 & 72 & 50 & & 72 & 85 & & & & & 73 & & 1 & & & & & & & & 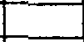 & & & & & 1 & 72 \\
\hline 12. Peach Bot. 2 & 72 & 60 & & 73 & 80 & 1 & 73 & 90 & & 74 & & 1 & 74 & & & & & & & & & & & & 2 & 73 \\
\hline Peach Bot. 3 & 73 & 30 & & 74 & 50 & 1 & 74 & 50 & & 74 & 85 & & 74 & & & & & & & & & & & & 1 & 74 \\
\hline 14. Salem 1 & 72 & 30 & & 73 & 60 & 1 & 74 & 70 & 1 & 75 & 75 & 1 & 76 & 85 & 1 & 76 & 95 & & 76 & & & 77 & & 1 & 5 & 76 \\
\hline Vermont Yan. & 71 & 70 & & 71 & 99 & & 72 & & $I$ & & & & & & & & & & & & & & & & 1 & 72 \\
\hline 16. Ft. Ca1houn 1 & 71 & 50 & & 72 & 65 & 1 & 73 & 90 & 1 & 73 & & & & & & & & & & & & & & & 2 & 73 \\
\hline 17. Surry 1 & 71 & 65 & & 72 & 95 & 1 & 72 & & & & & & & & & & & & & & & & & & 1 & 72 \\
\hline 18. Surry 2 & 72 & 35 & & 72 & 65 & & 73 & 96 & 1 & 73 & & & & & & & & & & & & & & & 1 & 73 \\
\hline 19. Diablo 1 & 73 & 35 & & 74 & 30 & 1 & 75 & 50 & 1 & 75 & 75 & & 76 & 90 & 1 & 76 & 93 & & 77 & 99 & 1 & 77 & & & 4 & \\
\hline 20. 3 Mile Is1. I & 72 & 40 & & 72 & 75 & & 72 & 90 & & 74 & 95 & 2 & 74 & & & & & & & & & & & & 2 & 74 \\
\hline $\begin{array}{c}\text { Aggregate Delays } \\
\text { (Years) }\end{array}$ & & & & & & 11 & & & 12 & & & 5 & & & 4 & & & 1 & & & 1 & & & 1 & 35 & \\
\hline
\end{tabular}

Easton*

*Niagara Mohawk Power, $750 \mathrm{MW}$, GE scheduled operation 71 (according to Electrical Wor1d, 1968) was ordered in 1966 and 1ater canceled to become Fitzpatrick in 1968. 
APPENDIX $\mathrm{C}$

UNI'TS ORDERED IN 1967*

\begin{tabular}{|c|c|c|c|c|c|c|c|c|c|c|c|c|c|c|c|c|c|c|c|c|c|c|c|c|c|c|c|}
\hline $\mathrm{P}_{\mathrm{A}}^{\mathrm{L}}$ & 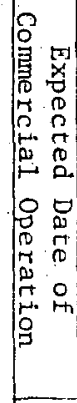 & $\begin{array}{l}7 \\
0 \\
0 \\
0 \\
0 \\
0 \\
0 \\
0 \\
0 \\
0 \\
0 \\
0 \\
0 \\
0 \\
0 \\
0 \\
0 \\
\end{array}$ & 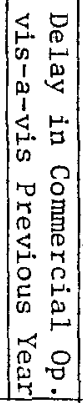 & 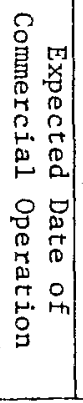 & $\begin{array}{l}0 \\
0 \\
0 \\
0 \\
0 \\
0 \\
i \\
0 \\
r \\
0 \\
0 \\
0 \\
0 \\
0 \\
0\end{array}$ & 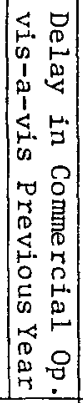 & 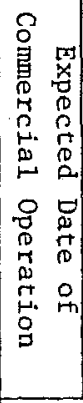 & $\begin{array}{c}0 \\
0 \\
0 \\
0 \\
0 \\
0 \\
0 \\
0 \\
0 \\
0 \\
0 \\
0 \\
0 \\
0 \\
0 \\
0 \\
\end{array}$ & 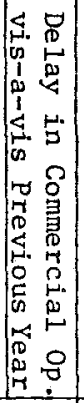 & 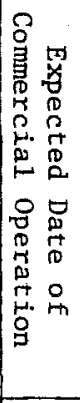 & $\begin{array}{l}1 \\
0 \\
0 \\
0 \\
0 \\
0 \\
0 \\
1 \\
5 \\
0 \\
0 \\
09 \\
0 \\
0 \\
0 \\
0 \\
0 \\
\end{array}$ & 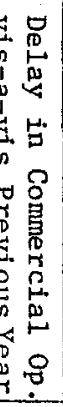 & 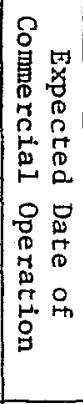 & 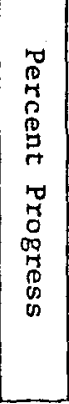 & 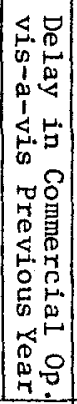 & 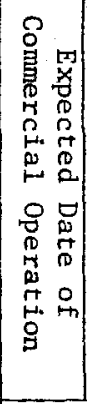 & $\begin{array}{l}n \\
0 \\
0 \\
0 \\
0 \\
0 \\
0 \\
0 \\
0 \\
0 \\
0 \\
0 \\
0 \\
0 \\
0 \\
0 \\
\\
\end{array}$ & 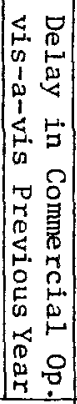 & 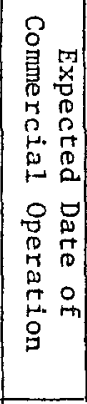 & \begin{tabular}{|l|} 
\\
0 \\
0 \\
0 \\
0 \\
0 \\
0 \\
0 \\
0 \\
0 \\
0 \\
0 \\
0 \\
0 \\
0 \\
0 \\
0 \\
0 \\
0 \\
\\
\end{tabular} & 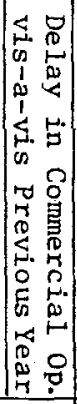 & 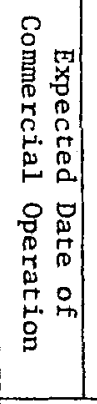 & $\begin{array}{l}0 \\
0 \\
0 \\
0 \\
0 \\
0 \\
0 \\
0 \\
0 \\
0 \\
0 \\
0 \\
0 \\
0 \\
0 \\
0 \\
0 \\
\end{array}$ & $\left|\begin{array}{ll}4 & 0 \\
0 & 0 \\
1 & 0 \\
0 & 0 \\
1 & 0 \\
4 & 4 \\
0 & 5 \\
0 & 2 \\
0 & 0 \\
0 & 5 \\
0 & 0 \\
5 & 0 \\
0 & 0 \\
0 & 0 \\
0 & 0 \\
0 & 0 \\
0 & 0 \\
0 & 0\end{array}\right|$ & \multirow[t]{2}{*}{ 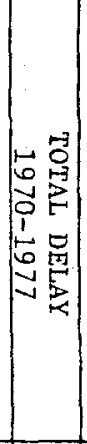 } & \multirow[t]{2}{*}{ 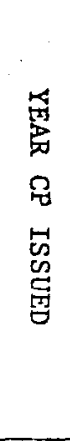 } & \multirow[t]{2}{*}{ 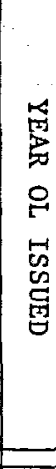 } \\
\hline & \multicolumn{3}{|c|}{1970} & \multicolumn{3}{|c|}{1971} & \multicolumn{3}{|c|}{1972} & \multicolumn{3}{|c|}{1973} & \multicolumn{3}{|c|}{1974} & \multicolumn{3}{|c|}{1975} & \multicolumn{3}{|c|}{1976} & \multicolumn{3}{|c|}{1977} & & & \\
\hline Bailey & 76 & & & 76 & & & 77 & & 1 & 78 & & 1 & 79 & & 1 & & 5 & & 82 & 25 & 3 & 82 & & & 6 & 74 & \\
\hline 2. Crysta1 R. 3 & 72 & 10 & & 73 & 40 & 1 & 74 & 55 & 1 & 75 & 80 & 1 & 75 & 93 & & 76 & 93 & 1 & 77 & & 1 & 77 & & & 5 & -70 & 76 \\
\hline 3. Kewaunee 1 & 72 & 40 & & 73 & 70 & 1 & 73 & 93 & & 73 & 99 & & 74 & & 1 & & & & & & & & & & 2 & -70 & 73 \\
\hline 4. M. Yankee & 72 & 40 & & 72 & 90 & & 72 & & & & & & & & & & & & & & & & & & & -70 & 72 \\
\hline 5. Pt. Beach 2 & 71 & 50 & & 72 & 95 & 1 & & & & 73 & & 1 & & & & & & & & & & & & & 2 & -70 & 71 \\
\hline 6. Prairie IsI.I & 72 & 40 & & 72 & 75 & & 73 & 90 & 1 & 73 & & & & & & & & & & & & & & & 1 & -70 & 73 \\
\hline 7. Shoreham & 75 & & & $76+$ & & 1 & 77 & & 1 & 77 & 5 & & 78 & 20 & 1 & 78 & 35 & & 79 & 52 & 1 & 79 & & & 4 & 73 & \\
\hline 8. 3 Mile Isl. 2 & 73 & 5 & & 74 & 20 & 1 & 75 & 25 & 1 & 76 & 45 & 1 & 77 & 60 & 1 & 78 & 70 & 1 & 78 & 85 & & 78 & & & 5 & -70 & \\
\hline 9. Zion 1 & 72 & 40 & & 72 & 70 & & 72 & & & 73 & & 1 & & & & & & & & & & & & & 1 & -70 & 73 \\
\hline 10. Arkansas 1 & 73 & 25 & & 73 & 60 & & 73 & 85 & & 74 & 99 & 1 & 74 & & & & & & & & & & & & 1 & -70 & 74 \\
\hline 11. Cooper & 72 & 40 & & 73 & 55 & 1 & 73 & 85 & & 74 & 98 & 1 & 74 & & & & & & & & & & & & 2 & -70 & 74 \\
\hline 12. Indian Pt. 3 & 73 & 30 & & 73 & 60 & & 74 & 70 & 1 & 74 & 85 & & 75 & 93 & 1 & 76 & 99 & 1 & 76 & & 1 & & & & 3 & -70 & 75 \\
\hline 13. Turkey Pt. 4 & 72 & 60 & & 72 & 80 & & 73 & 97 & 1 & 73 & & & & & & & & & & & & & & & 1 & -70 & 73 \\
\hline 14. Calvert Cl.il & 73 & 25 & & 73 & 55 & & 74 & 70 & 1 & 74 & 85 & & 74 & 96 & & 75 & & 1 & & & & & & & 2 & -70 & 74 \\
\hline 15. Calvert $\mathrm{C} 1.2$ & 74 & 15 & & 74 & 35 & & 75 & 55 & 1 & 75 & 70 & & 77 & 68 & 2 & 77 & 85 & & 77 & & & 77 & & & 3 & -70 & 76 \\
\hline 16. Oconee 3 & 73 & 15 & & 73 & 40 & & 74 & 45 & 1 & 74 & 89 & & 74 & & & & & & & & & & & & 1 & -70 & 74 \\
\hline 17. Salem 2 & 73 & 15 & & 74 & 40 & $I$ & 75 & 35 & 1 & 76 & 32 & 1 & 79 & 45 & 3 & 79 & 55 & & 79 & 59 & & 79 & & & 6 & -70 & \\
\hline
\end{tabular}

-CONTINUED- 
UNIT'S ORDERED IN $1967 *$

-CONTINUED-

\begin{tabular}{|c|c|c|c|c|c|c|c|c|c|c|c|c|c|c|c|c|c|c|c|c|c|c|c|c|c|c|c|}
\hline $\begin{array}{l}\mathrm{P} \\
\mathrm{L} \\
\mathrm{A} \\
\\
\\
\mathrm{N}\end{array}$ & 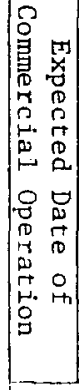 & $\begin{array}{l}0 \\
0 \\
0 \\
0 \\
0 \\
0 \\
7 \\
\pi \\
7 \\
7 \\
0 \\
0 \\
0 \\
0 \\
0 \\
0 \\
0\end{array}$ & 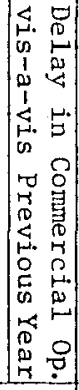 & 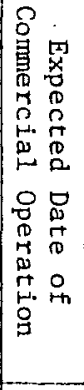 & $\begin{array}{l}0 \\
0 \\
0 \\
0 \\
0 \\
0 \\
0 \\
0 \\
0 \\
0 \\
0 \\
0 \\
0 \\
0 \\
0 \\
0 \\
0\end{array}$ & 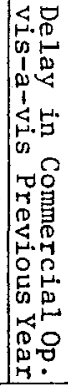 & 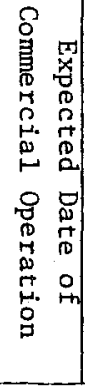 & $\begin{array}{l}0 \\
0 \\
0 \\
0 \\
0 \\
0 \\
9 \\
7 \\
10 \\
4 \\
0 \\
0 \\
00 \\
7 \\
0 \\
0 \\
0\end{array}$ & 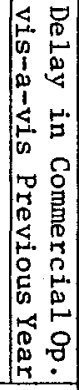 & 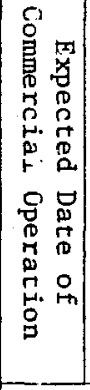 & $\begin{array}{l}0 \\
0 \\
0 \\
0 \\
0 \\
0 \\
0 \\
7 \\
0 \\
0 \\
0 \\
0 \\
00 \\
0 \\
0 \\
0 \\
0 \\
0\end{array}$ & 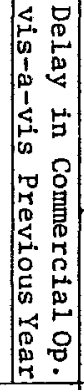 & 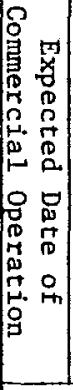 & $\begin{array}{l}0 \\
0 \\
0 \\
0 \\
0 \\
9 \\
9 \\
7 \\
0 \\
7 \\
0 \\
0 \\
0 \\
0 \\
0 \\
0 \\
0 \\
0\end{array}$ & 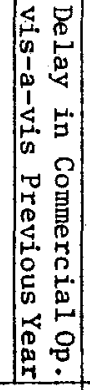 & 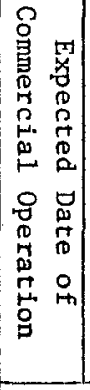 & $\begin{array}{l}0 \\
0 \\
0 \\
0 \\
0 \\
0 \\
0 \\
1 \\
0 \\
0 \\
0 \\
0 \\
0 \\
7 \\
0 \\
0 \\
0 \\
0 \\
\end{array}$ & 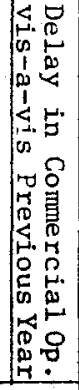 & 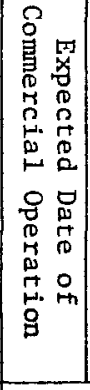 & $\begin{array}{l}0 \\
0 \\
0 \\
0 \\
0 \\
0 \\
0 \\
7 \\
0 \\
0 \\
0 \\
0 \\
09 \\
7 \\
0 \\
0 \\
6\end{array}$ & 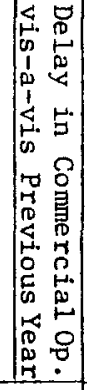 & 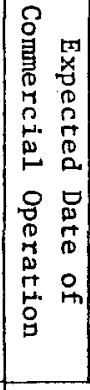 & $\begin{array}{l}0 \\
0 \\
0 \\
1 \\
0 \\
0 \\
0 \\
7 \\
1 \\
0 \\
0 \\
0 \\
0 \\
0 \\
0 \\
0 \\
0 \\
0 \\
0\end{array}$ & 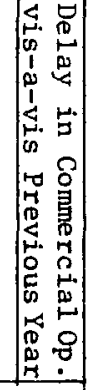 & \multirow[t]{2}{*}{ 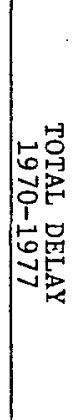 } & \multirow[t]{2}{*}{ 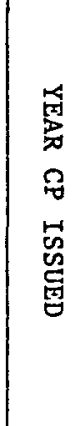 } & \multirow[t]{2}{*}{ 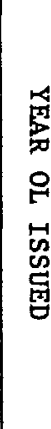 } \\
\hline & \multicolumn{3}{|c|}{1970} & \multicolumn{3}{|c|}{1971} & \multicolumn{3}{|c|}{1972} & \multicolumn{3}{|c|}{1973} & \multicolumn{3}{|c|}{1974} & \multicolumn{3}{|c|}{1975} & \multicolumn{3}{|c|}{1976} & \multicolumn{3}{|c|}{1977} & & & \\
\hline 18. Browns Fer. 3 & 72 & 30 & & 73 & 50 & 1 & 74 & 40 & 1 & 75 & 35 & 1 & 75 & 75 & & 76 & 93 & 1 & 77. & 99 & 1 & 77 & & & 5 & -70 & 76 \\
\hline 19. Prairie Is1. 2 & 74 & 20 & & 74 & 45 & & 74 & 35 & & 74 & 65 & & 74 & & & & & & & & & & & & & -70 & 74 \\
\hline 20. Cook 1 & 72 & 20 & & 73 & 50 & 1 & 73 & 75 & & $\overline{7} \overline{4}$ & 95 & 1 & 75 & 96 & 1 & 75 & & & & & & & & & 3 & -70 & 74 \\
\hline 21. Cook 2 & 73 & 10 & & 74 & 30 & 1 & 75 & 50 & 1 & 76 & 60 & 1 & 76 & 51 & & 78 & 57 & 2 & 78 & 85 & & 78 & & & 5 & -70 & \\
\hline 22. Zion 2 & 73 & 25 & & 73 & 50 & & 73 & & & 74 & 90 & 1 & 74 & & & & & & & & & & & & 1 & -70 & 73 \\
\hline 23. Rancho Seco & 73 & 30 & & 73 & 50 & & 74 & 75 & 1 & $7 \overline{4}$ & 93 & & 75 & 99 & 1 & 75 & & & & & & & & & 2 & -70 & 74 \\
\hline 24. Beaver Valley & 73 & & & 74 & 30 & 1 & 74 & 50 & & 74 & 65 & & 75 & 92 & 1 & 76 & 99 & 1 & 76 & & & & & & 3 & 70 & 76 \\
\hline Limerick 1 & 75 & & & 75 & & & 79 & & 4 & 79 & 1 & & 81 & 2 & 2 & 81 & 17 & & 83 & 30 & 2 & 83 & & & 8 & 74 & \\
\hline Limerick 2 & 77 & & & 77 & & & 80 & & 3 & 81 & 1 & 1 & 83 & 1 & 2 & 83 & 4 & & 85 & 19 & 2 & 85 & & & 8 & 74 & \\
\hline North Anna 1 & 74 & & & 75 & 20 & 1 & 75 & 50 & & 75 & 60 & & 75 & 80 & & 77 & 85 & 2 & 77 & 96 & & 77 & & & 3 & 71 & \\
\hline 28. Hatch 1 & 73 & 30 & & 73 & 55 & & 74 & 65 & 1 & 74 & 90 & & 74 & & & 75 & & 1 & & & & & & & 2 & -70 & 74 \\
\hline 29. St. Lucie & 73 & 5 & & 74 & 25 & 1 & 74 & 37 & & 73 & 60 & 1 & 75 & 80 & & 75 & 98 & & 76 & & 1 & & & & 3 & 70 & 76 \\
\hline 30. Millstone 2 & 74 & & & 74 & 25 & & 74 & 45 & & 75 & 70 & 1 & 75 & 90 & & 75 & & & & & & & & & 1 & 70 & 75 \\
\hline 31. Be 11 & & & & & & & & & & C & $\mathrm{AN}$ & C E & L E & D & & & & & & & & & & & & & \\
\hline $\begin{array}{c}\text { Aggregate Delays } \\
\text { (Years) }\end{array}$ & & & & & & 13 & & & 22 & & & 15 & & & 17 & & & 11 & & & 11 & & & & 89 & & \\
\hline
\end{tabular}

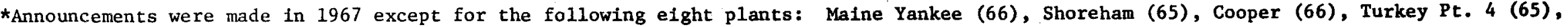
Salem 2 (66), Cook (66), Rancho Seco (66), St. Lucle (68).

†Public hearing delayed. 
APPENDIX C

UNITS ORDERED IN $1968^{1}$

\begin{tabular}{|c|c|c|c|c|c|c|c|c|c|c|c|c|c|c|c|c|c|c|c|c|c|c|c|c|c|c|c|}
\hline $\mathrm{P}_{\mathrm{A}}^{\mathrm{P}} \mathrm{N}_{\mathrm{T}}$ & 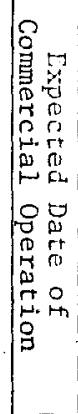 & $\begin{array}{l}r \\
0 \\
0 \\
0 \\
0 \\
0 \\
0 \\
i \\
0 \\
0 \\
0 \\
0 \\
0 \\
0 \\
0 \\
0 \\
0\end{array}$ & 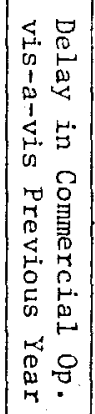 & 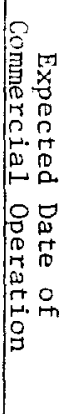 & $\begin{array}{l} \\
0 \\
0 \\
0 \\
0 \\
0 \\
0 \\
0 \\
0 \\
0 \\
0 \\
0 \\
0 \\
0 \\
0 \\
0 \\
0 \\
0 \\
\end{array}$ & 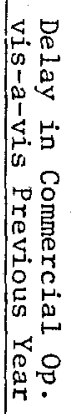 & 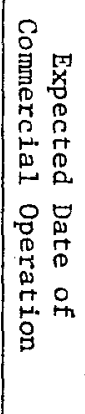 & $\begin{array}{l} \\
\\
0 \\
0 \\
0 \\
0 \\
0 \\
0 \\
0 \\
0 \\
0 \\
0 \\
0 \\
0 \\
0 \\
0 \\
0 \\
\end{array}$ & 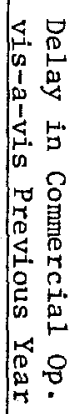 & 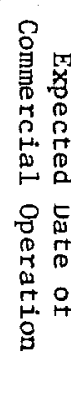 & $\begin{array}{l} \\
\\
0 \\
0 \\
0 \\
0 \\
0 \\
0 \\
0 \\
0 \\
0 \\
0 \\
0 \\
0 \\
0 \\
0 \\
0 \\
0 \\
0 \\
0 \\
\end{array}$ & 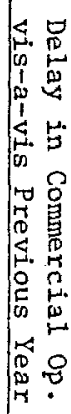 & 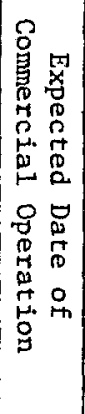 & $\begin{array}{l} \\
0 \\
0 \\
0 \\
0 \\
0 \\
0 \\
+1 \\
0 \\
0 \\
0 \\
0 \\
0 \\
0 \\
0 \\
0 \\
\infty \\
\end{array}$ & 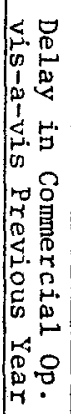 & 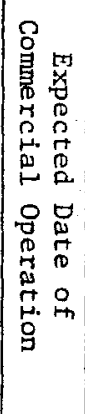 & 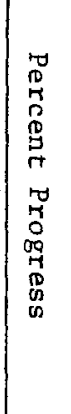 & 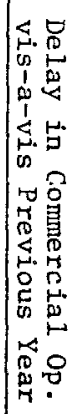 & 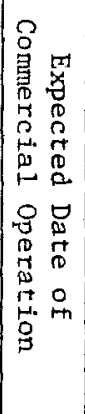 & $\begin{array}{c} \\
0 \\
0 \\
0 \\
0 \\
0 \\
9 \\
0 \\
0 \\
0 \\
0 \\
0 \\
0 \\
0 \\
0 \\
0 \\
0 \\
0 \\
\end{array}$ & 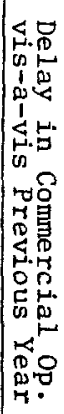 & 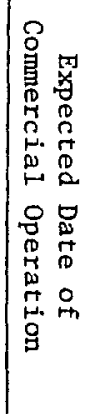 & $\begin{array}{l} \\
\\
0 \\
0 \\
0 \\
0 \\
9 \\
9 \\
7 \\
0 \\
10 \\
0 \\
00 \\
0 \\
0 \\
0 \\
0\end{array}$ & 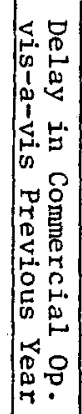 & \multirow[t]{2}{*}{ 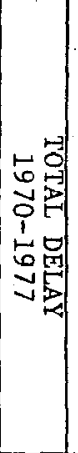 } & \multirow[t]{2}{*}{ 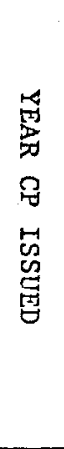 } & \multirow[t]{2}{*}{ 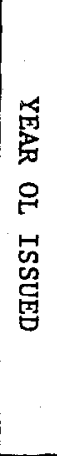 } \\
\hline & \multicolumn{3}{|c|}{1970} & \multicolumn{3}{|c|}{$\frac{1}{1971}$} & \multicolumn{3}{|c|}{$\frac{1}{1972}$} & \multicolumn{3}{|c|}{1973} & \multicolumn{3}{|c|}{1974} & \multicolumn{3}{|c|}{1975} & \multicolumn{3}{|c|}{1976} & \multicolumn{3}{|c|}{1977} & & & \\
\hline 1. Brunswick 1 & 75 & 5 & & 76 & 15 & 1 & 73 & 35 & -1 & 75 & 50 & & 75 & 65 & & 77 & 75 & 2 & 77 & 96 & & 77 & & & 2 & 70 & 76 \\
\hline 2. Brunswick 2 & 74 & 10 & & 74 & 30 & & 74 & 65 & & 74 & 80 & & 75 & 90 & 1 & 75 & & & & & & & & & 1 & 70 & 74 \\
\hline 3. Arnold 1 & 73 & & & 74 & 25 & 1 & 73 & 70 & -1 & 74 & 96 & 1 & 74 & & & 75 & & 1 & & & & & & & $\frac{2}{2}$ & 70 & 74 \\
\hline 4. Sequoyah 1 & 73 & & & 74 & 25 & 1 & 74 & 45 & & 75 & 55 & 1 & 76 & 90 & 1 & 77 & 69 & 1 & 78 & 80 & 1 & 78 & & & 5 & 70 & \\
\hline 5. Sequnyah 2 & 74 & & & 75 & 15 & 1 & 75 & 35 & & 76 & 45 & 1 & 77 & 60 & 1 & 78 & 69 & 1 & 79 & 70 & 1 & 79 & & & 5 & 70 & \\
\hline 6. Midland 1 & 74 & & & 76 & & 2 & 18 & & 2 & 80 & & 2 & 80 & 5 & & 82 & 10 & 2 & 82 & 17 & & 82 & & & 8 & 72 & \\
\hline 7. Midland 2 & 75 & & & 77 & & 2 & 79 & & $\frac{5}{2}$ & 79 & 5 & & 79 & $\frac{2}{10}$ & & 81 & 10 & $\frac{2}{2}$ & 81 & 17 & & 81 & & & $\frac{5}{6}$ & 72 & \\
\hline 8. Susquehana 1 & 77 & & & 78 & & $\overline{1}$ & 79 & & I & 79 & & & 80 & 5 & 1 & 80 & 13 & & 80 & 33 & & 80 & & & 3 & 73 & \\
\hline 9. Susquehana 2 & 79 & & & 80 & & 1 & 81 & & 1 & 81 & & & 82 & 5 & 1 & 82 & $\frac{5}{5}$ & & 82 & 22 & & 82 & & & $\frac{5}{3}$ & 73 & \\
\hline 10. Diablo 2 & 74 & & & 75 & 5 & $\frac{1}{1}$ & 76 & 12 & 1 & 76 & 35 & & 76 & 50 & & 77 & 60 & 1 & 78 & 83 & 1 & 78 & & & $\frac{5}{4}$ & 70 & \\
\hline 11. Fermi 2 & 74 & & & 75 & & 1 & 76 & & 1 & 77 & 40 & $I$ & 79 & 45 & 2 & 80 & & 1 & 80 & 45 & & 80 & & & 6 & 72 & \\
\hline 12. Davis Besse 1 & 74 & & & 75 & 15 & 1 & 75 & 35 & & 75 & 55 & & 76 & 68 & 1 & 76 & 90 & & 77 & 99 & 1 & 77 & & & 3 & 71 & \\
\hline 13. Trojan & 74 & & & 75 & 10 & 1 & 74 & 55 & -1 & 74 & 75 & & 75 & 85 & 1 & 75 & 95 & & 76 & & 1 & & & & 2 & 71 & 75 \\
\hline 14. Fitzpatrick & 73 & & & 73 & 35 & & 73 & 75 & & 74 & 93 & 1 & 74 & 99 & & 75 & & $I$ & & & & & & & 2 & 70 & 74 \\
\hline $\begin{array}{c}\text { Aggregate Delays } \\
\text { (Years) }\end{array}$ & & & & & & 14 & & & 5 & & & 7 & & & 9 & & & 12 & & & 5 & & & & 52 & & \\
\hline $\begin{array}{l}\text { 15. Carolina P\&L } \\
\text { Unit } 42^{2}\end{array}$ & & & & & & & & & & & 0 & $\mathbf{p}$ & $\mathrm{E}$ & $\mathrm{N}$ & & & & & & & & & & & & & \\
\hline 16. Verplanck ${ }^{3}$ & 75 & & & 77 & 78 & 1 & & & & $\bar{D}$ & $E$ & $\mathrm{~L}$ & A & $\mathrm{Y}$ & $\mathrm{D}$ & & & & & & & & & & & & \\
\hline $\begin{array}{c}\text { Aggregate Delays } \\
\text { (Years) }\end{array}$ & & & & & & 1 & & & & & & & & & & & & & & & & & & & & & \\
\hline
\end{tabular}

1. Announcements were made in 1968 except for the following four plants: Midland 1, 2, Susquehana 1, Trojan. These announcements were made in 1967.

2. $821 \mathrm{MW}$ station supplied by GE was announced on January $24,1968$.

3. Consolidated Edison 1,125 MW, GE-BWR (Peeksville, New York) is delayed due to uncertainty on cooling system. Announcements were made on January $10,1968$. 


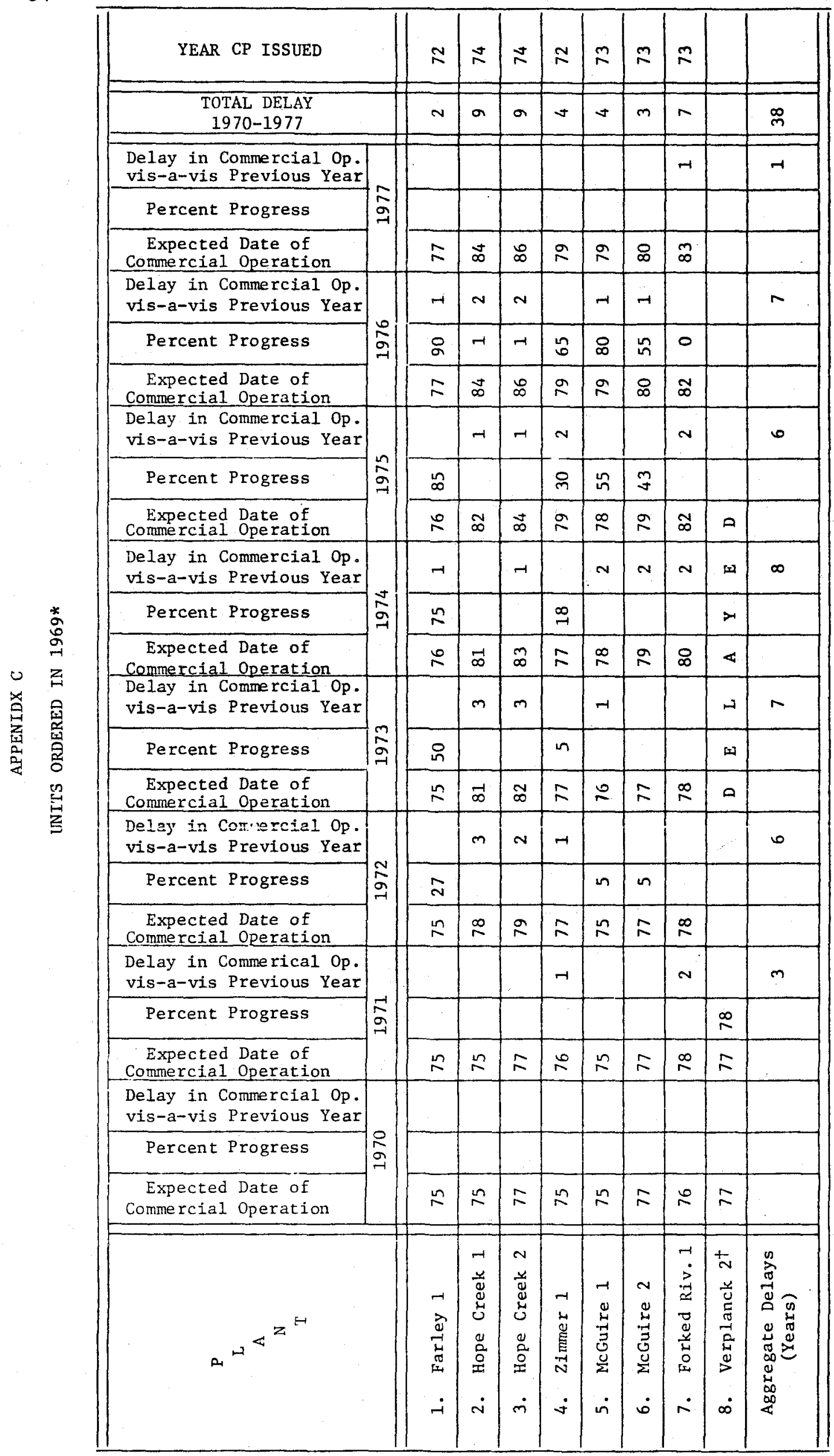


APPENDIX $\mathrm{C}$

UNITS ORDERED IN $1970^{1}$

\begin{tabular}{|c|c|c|c|c|c|c|c|c|c|c|c|c|c|c|c|c|c|c|c|c|c|c|c|c|c|c|}
\hline 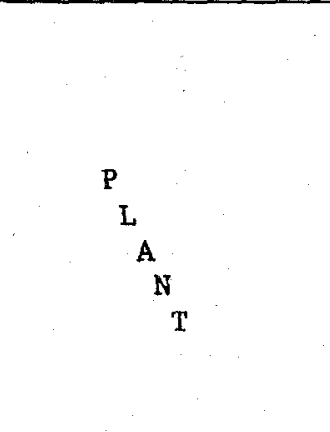 & 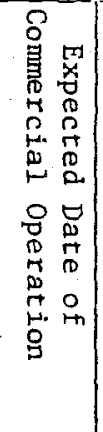 & $\begin{array}{l}0 \\
0 \\
0 \\
\tilde{n} \\
0 \\
0 \\
\pi \\
0 \\
0 \\
0 \\
0 \\
0 \\
0 \\
0 \\
0\end{array}$ & 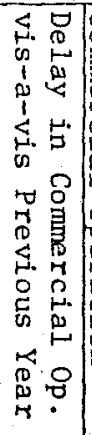 & 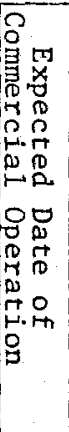 & 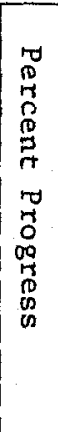 & 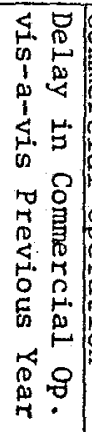 & 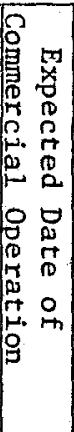 & $\begin{array}{l}0 \\
0 \\
0 \\
0 \\
0 \\
0 \\
0 \\
0 \\
0 \\
0 \\
0 \\
0 \\
0 \\
0 \\
0 \\
0 \\
0 \\
0 \\
0\end{array}$ & 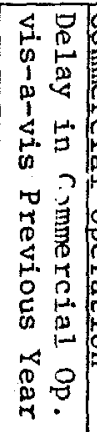 & 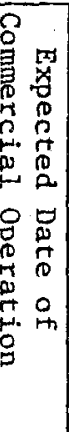 & 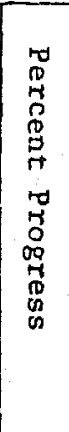 & 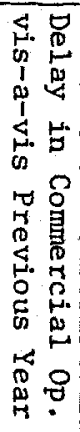 & 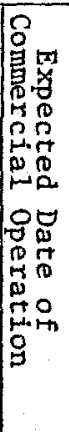 & $\begin{array}{l}0 \\
0 \\
0 \\
0 \\
0 \\
0 \\
0 \\
0 \\
1 \\
0 \\
0 \\
0 \\
0 \\
0 \\
0 \\
0 \\
0 \\
0\end{array}$ & 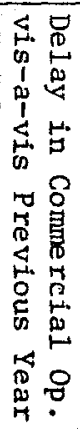 & 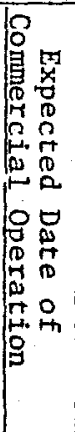 & $\begin{array}{l}0 \\
0 \\
0 \\
0 \\
0 \\
0 \\
0 \\
7 \\
+0 \\
0 \\
0 \\
0 \\
0 \\
0 \\
0 \\
0 \\
0 \\
0\end{array}$ & 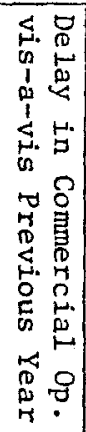 & 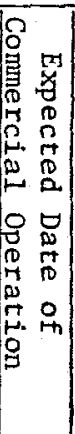 & $\begin{array}{c}0 \\
0 \\
0 \\
0 \\
0 \\
0 \\
0 \\
0 \\
0 \\
0 \\
0 \\
0 \\
0 \\
0 \\
0 \\
0 \\
0 \\
0\end{array}$ & 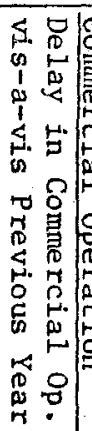 & 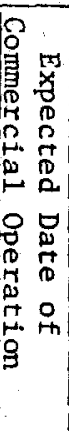 & $\begin{array}{l}0 \\
0 \\
0 \\
0 \\
0 \\
0 \\
0 \\
0 \\
0 \\
0 \\
0 \\
0 \\
0 \\
0 \\
0 \\
0 \\
0 \\
0\end{array}$ & 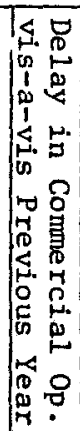 & \multirow[t]{2}{*}{ 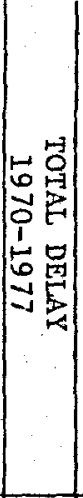 } & \multirow[t]{2}{*}{$\begin{array}{l}2 \\
8 \\
0 \\
0 \\
0 \\
0\end{array}$} \\
\hline & \multicolumn{3}{|c|}{1970} & \multicolumn{3}{|c|}{1971} & \multicolumn{3}{|c|}{1972} & \multicolumn{3}{|c|}{1973} & \multicolumn{3}{|c|}{1974} & \multicolumn{3}{|c|}{1975} & \multicolumn{3}{|c|}{1976} & \multicolumn{3}{|c|}{1977} & & \\
\hline 1. North Anna 2 & 75 & & & 75 & 50 & & 75 & 50 & & 75 & 40 & 1 & 76 & 60 & & 77 & 55 & 1 & 78 & 74 & 1 & 78 & & & 3 & 71 \\
\hline 2. San Onofre 2 & 75 & & & 76 & & 1 & 78 & & 2 & 78 & & & 80 & 5 & 2 & 81 & 8 & 1 & 81 & 27 & & 81 & & & 6 & 73 \\
\hline 3. San Onofre 3 & 76 & & & 77 & & 1 & 79 & & 2 & 79 & & & 81 & 5 & 2 & 83 & 8 & 2 & 83 & 27 & & 83 & & & 7 & 73 \\
\hline 4. Hatch 2 & 76 & & & 76 & & & 77 & 5 & 1 & 78 & 15 & 1 & 78 & 25 & & 79 & 30 & 1 & 79 & 70 & & 79 & & & 3 & 72 \\
\hline 5. Aguirre 2 & 75 & & & 76 & & 1 & 78 & 5 & 2 & & & & & & & & & & & & & & & & 3 & \\
\hline 6. Arkansas 2 & 76 & & & 77 & & 1 & 77 & 7 & & 77 & 16 & & 77 & 37 & & & 49 & & 78 & 76 & 1 & 78 & & & 2 & 72 \\
\hline 7. LaSalle 1 & 75 & & & 75 & & & 77 & & 2 & 78 & & 1 & 78 & 5 & & 78 & 15 & & 79 & 40 & 1 & 79 & & & 4 & 73 \\
\hline 8. LaSa11e 2 & 76 & & & 76 & & & 78 & & 2 & 19 & & 1 & 79 & 5 & & 79 & 10 & & 79 & 35 & & 80 & & 1 & 4 & 73 \\
\hline 9. Bellefonte 1 & 77 & & & 77 & & & 79 & & 2 & 79 & & & 79 & & & 80 & 5 & 1 & 80 & 24 & & 80 & & & 3 & 74 \\
\hline 10. Bellefonte 2 & 78 & & & 78 & & & 79 & & 1 & 80 & & 1 & 80 & & & 81 & 5 & 1 & 81 & 16 & & 81 & & & 3 & 74 \\
\hline 11. Watts Bar 1 & 76 & & & 77 & & 1 & 77 & & & 78 & 5 & 1 & 78 & 13 & & 78 & 25 & & 79 & 51 & 1 & 79 & & & 3 & 73 \\
\hline 12. Watts Bar 2 & 77 & & & 77 & & & 78 & & 1 & 78 & 5 & & 79 & 13 & 1 & 79 & 25 & & 80 & 43 & 1 & 80 & & & 3 & 73 \\
\hline 13. Waterford 3 & & & & 77 & & & 77 & & & 783 & & 1 & 79 & & 1 & 81 & 2 & 2 & 81 & 17 & & 81 & & & 4 & 74 \\
\hline 14. Farley 2 & 77 & & & 77 & & & 77 & & & 77 & 15 & & 77 & 30 & & 77 & 45 & & 79 & 40 & 2 & 79 & & & 2 & 72 \\
\hline 15. Waterford 44 & & & & 78 & & & & & & & & & & & & & & & & & & & & & & \\
\hline $\begin{array}{c}\text { Aggregate Delays } \\
\text { (Years) }\end{array}$ & & & & & & 5 & & & 15 & & & 7 & & & 6 & & & 9 & & & 7 & & & 1 & 50 & \\
\hline
\end{tabular}

1. Announcements are made in 1970 for all units except North Anna (67)

2. Original location Guayama, P.R. is canceled. New project NORCO-NP-1 is announced in September of 1974 .

3. Public hearing and antitrust delays.

4. Louisiana Power and Light 1,165 MW (C-E, PWR: Westinghouse) announced September $24,1970$. 
APPENDIX C

UNITS ORDERED IN 1971

\begin{tabular}{|c|c|c|c|c|c|c|c|c|c|c|c|c|c|c|c|c|c|c|c|c|c|c|c|}
\hline $\begin{array}{l}\mathrm{P} \\
\mathrm{L} \\
\mathrm{A} \\
\mathrm{T}\end{array}$ & 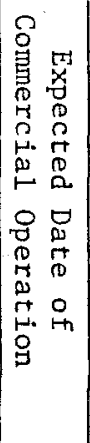 & $\begin{array}{l}0 \\
0 \\
0 \\
0 \\
0 \\
0 \\
0 \\
0 \\
\pi \\
0 \\
7 \\
0 \\
0 \\
00 \\
0 \\
0 \\
0 \\
0 \\
0\end{array}$ & 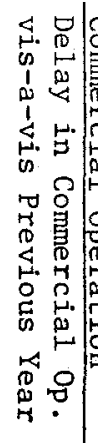 & 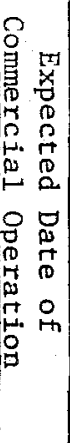 & 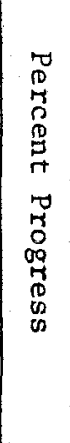 & 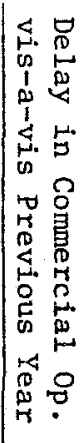 & 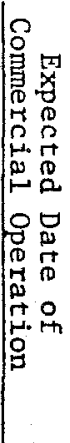 & $\begin{array}{l}n \\
0 \\
0 \\
0 \\
0 \\
0 \\
0 \\
\pi \\
0 \\
0 \\
0 \\
0 \\
00 \\
0 \\
0 \\
0 \\
0 \\
0\end{array}$ & 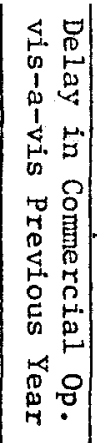 & 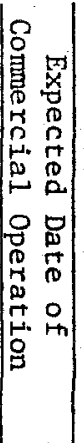 & $\begin{array}{l}7 \\
0 \\
0 \\
0 \\
0 \\
0 \\
0 \\
0 \\
0 \\
0 \\
09 \\
0 \\
0 \\
0 \\
0\end{array}$ & 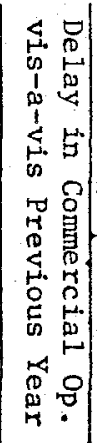 & 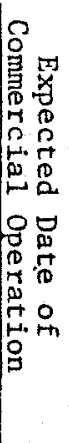 & $\begin{array}{c}0 \\
0 \\
0 \\
0 \\
0 \\
8 \\
0 \\
0 \\
0 \\
0 \\
0 \\
0 \\
0 \\
0 \\
0 \\
0\end{array}$ & 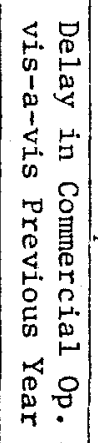 & 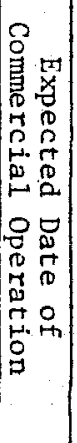 & $\begin{array}{l}0 \\
0 \\
0 \\
0 \\
0 \\
D \\
7 \\
+1 \\
0 \\
1 \\
0 \\
0 \\
0 \\
0 \\
0 \\
0 \\
0\end{array}$ & 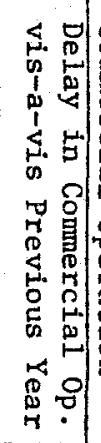 & 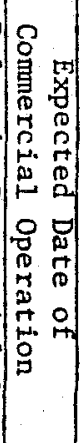 & $\begin{array}{l}0 \\
0 \\
0 \\
7 \\
0 \\
0 \\
0 \\
0 \\
0 \\
7 \\
0 \\
0 \\
0 \\
1 \\
0 \\
0 \\
0\end{array}$ & 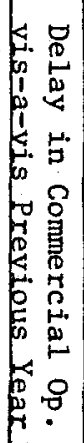 & \multirow[t]{2}{*}{ 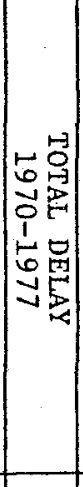 } & \multirow[t]{2}{*}{ 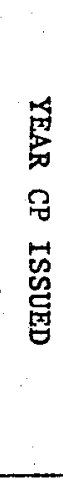 } \\
\hline & \multicolumn{3}{|c|}{1971} & \multicolumn{3}{|c|}{1972} & \multicolumn{3}{|c|}{1973} & \multicolumn{3}{|c|}{1974} & \multicolumn{3}{|c|}{1975} & \multicolumn{3}{|c|}{1976} & \multicolumn{3}{|c|}{1977} & & \\
\hline 1. Mendochino $1^{1}$ & 77 & & & 79 & & 2 & & & & & & & & & & & & & & & & 2 & \\
\hline 2. Mendochino 2 & 77 & & & 79 & & 2 & & & & & & & & & & & & & & & & 2 & \\
\hline 3. Summer 1 & 77 & & & 77 & & & 78 & & 1 & 78 & 5 & & 79 & 17 & 1 & 79 & 45 & & 80 & & $I$ & 3 & 73 \\
\hline 4. WPPSS 22 & 77 & & & 77 & & & 77 & 2 & & 78 & 10 & 1 & 78 & 23 & & 80 & 35 & 2 & 80 & & & 3 & 73 \\
\hline 5. Harris 1 & 77 & & & 77 & & & 78 & & 1 & 81 & & 3 & 84 & 5 & 3 & 84 & $<5$ & & 84 & & & 7 & \\
\hline 6. Harris 2 & 78 & & & 78 & & & 79 & & 1 & 82 & & 3 & 86 & 5 & 4 & 86 & $<5$ & & 86 & & & 8 & \\
\hline 7. Harris 3 & 79 & & & 79 & & & 80 & & 1 & 83 & & 3 & 90 & 5 & 7 & 90 & $\leq 5$ & & 90 & & & 11 & \\
\hline 8. Harris 4 & 80 & & & 80 & & & 81 & & 1 & 84 & & 3 & 88 & 5 & 4 & 88 & $<5$ & & 88 & & & 8 & \\
\hline 9. Byron 1 & 78 & & & 78 & & & 79 & & 1 & 80 & & 1 & 80 & 1 & & 80 & 15 & & 81 & & 1 & 3 & 75 \\
\hline 10. Byron 2 & 79 & & & 79 & & & 80 & & 1 & 81 & & 1 & 82 & 1 & 1 & 82 & 10 & & 82 & & & 3 & 75 \\
\hline 11. North Anna 3 & 77 & & & 77 & & & 77 & & & 78 & 5 & 1 & 80 & 5 & 2 & 81 & 4 & 1 & 82 & & 1 & 5 & 74 \\
\hline 12. North Anna 43 & 78 & & & 78 & & & 78 & & & 79 & 2 & 1 & 81 & 2 & 2 & 81 & 2 & & 83 & & 2 & 5 & 74 \\
\hline 13. Vogtle 14 & 78 & & & 80 & & 2 & 80 & & & & & & & & & 83 & 0 & 3 & 83 & & & 5 & 74 \\
\hline 14. Vogtle 2 & 79 & & & 81 & & 2 & 81 & & & & & & & & & 84 & 0 & 3 & 84 & & & 5 & 74 \\
\hline 15. Beaver valley 2 & & & & 78 & & & 78 & & & 81 & & 3 & 81 & & & 82 & & 1 & 82 & & & 4 & 74 \\
\hline 16. Nine Mile Point 2 & & & & 78 & & & 78 & & & 80 & & 2 & 82 & 1 & 2 & 82 & 5.5 & & 82 & & & 4 & 74 \\
\hline 17. Sunmit 1 & & & & 79 & & & 79 & & & 80 & & 1 & 81 & & 1 & & & & & & & & \\
\hline 18. Summit 2 & & & & 82 & & & 82 & & & 82 & & & 84 & & 2 & & & & & & & & \\
\hline 19. Fulton 1 & 79 & & & 79 & & & 81 & & 2 & 84 & & 3 & & & & & & & & & - & & \\
\hline 20. Fulton 2 & 79 & & & 81 & & 2 & 83 & & 2 & 86 & & 3 & & & & & & & & & & & \\
\hline $\begin{array}{c}\text { Aggregate Delays } \\
\text { (Years) }\end{array}$ & & & & & & 6 & & & 11 & & & 29 & & & 29 & & & 10 & & & 5 & 90 & \\
\hline
\end{tabular}

1. PG \& E Units. Alternate sites under consideration. Aggregate Delays (Years) are not shown for this plant.

2. WPPSS announcement was made in February of 1967 , a11 the rest were made in 1971.

3. Future status of this unit is currently under review.

4. Georgia Power Company units were suspended in September of 1974. 
APPENDIX C

UNITS ORDERED IN $1972^{1}$

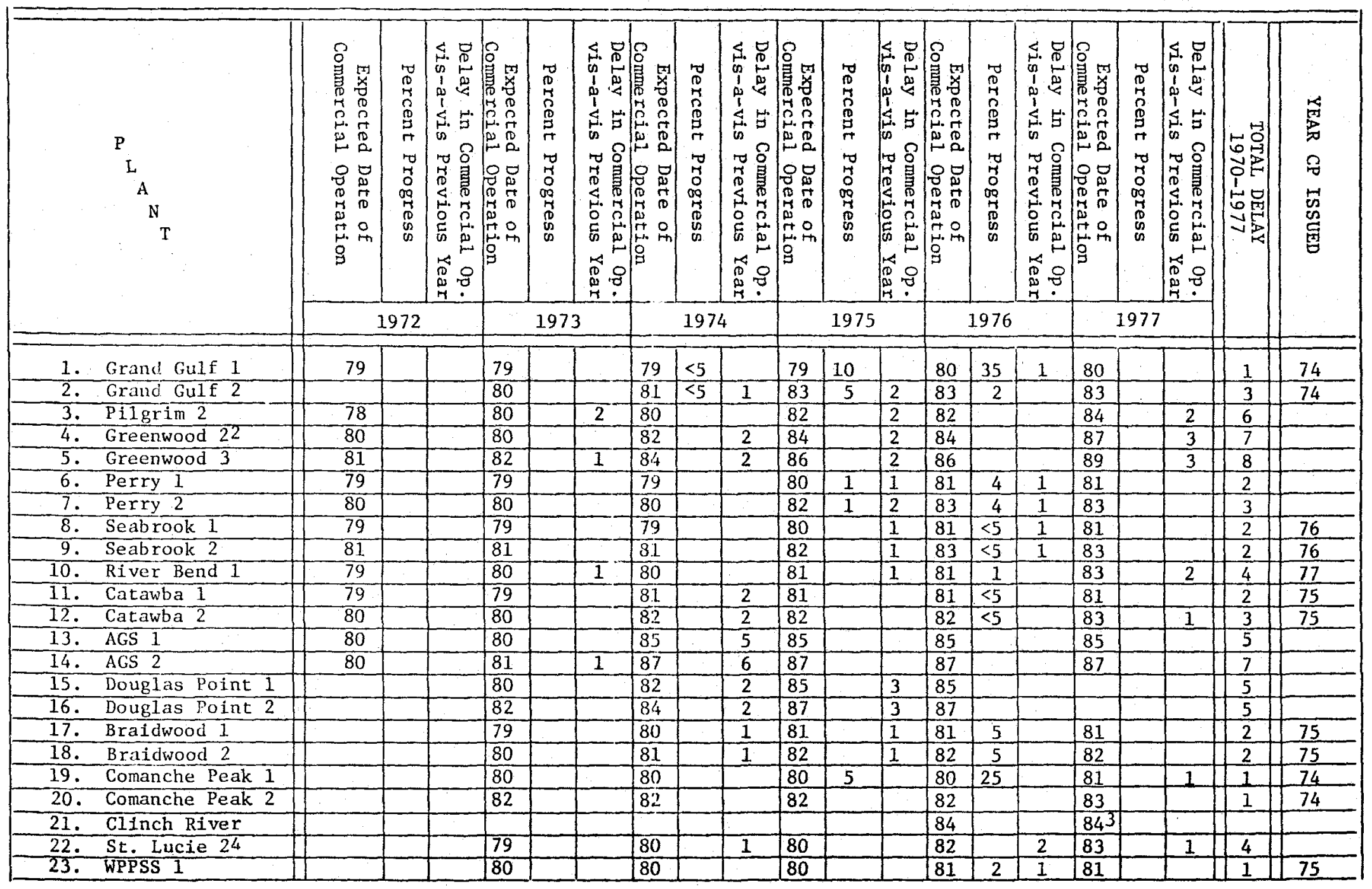

-CONTINUED- 
APPENDIX C

UNITS ORDERED IN $1972^{1}$

-CONTINUED-

\begin{tabular}{|c|c|c|c|c|c|c|c|c|c|c|c|c|c|c|c|c|c|c|c|c|}
\hline \multirow[t]{2}{*}{ 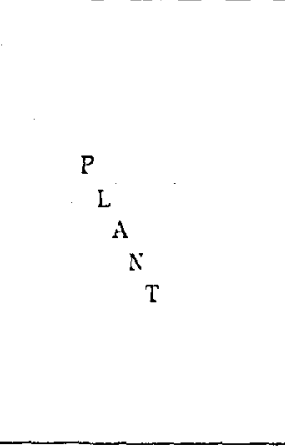 } & 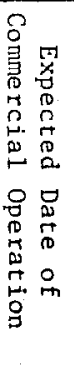 & 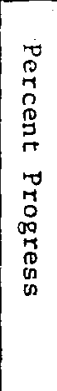 & 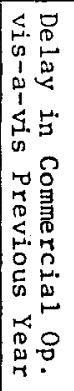 & 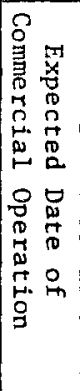 & \begin{tabular}{l|} 
\\
0 \\
0 \\
0 \\
0 \\
0 \\
0 \\
7 \\
0 \\
5 \\
0 \\
0 \\
0 \\
0 \\
0 \\
0 \\
0
\end{tabular} & 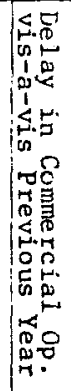 & 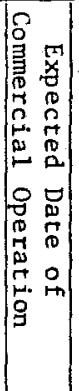 & $\begin{array}{l}0 \\
0 \\
0 \\
0 \\
0 \\
0 \\
0 \\
0 \\
0 \\
0 \\
0 \\
0 \\
0 \\
0 \\
0 \\
0 \\
0 \\
0\end{array}$ & 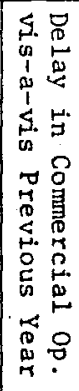 & 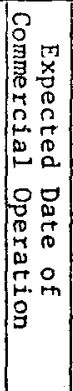 & $\begin{array}{l}7 \\
0 \\
0 \\
0 \\
0 \\
9 \\
7 \\
7 \\
7 \\
0 \\
09 \\
0 \\
0 \\
0 \\
0 \\
0\end{array}$ & 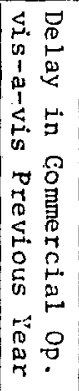 & 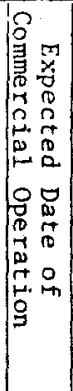 & $\begin{array}{c}7 \\
0 \\
0 \\
7 \\
0 \\
0 \\
0 \\
7 \\
0 \\
0 \\
7 \\
0 \\
0 \\
0 \\
0 \\
0 \\
0 \\
0\end{array}$ & 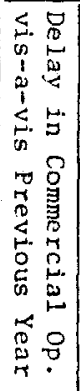 & 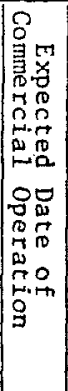 & $\begin{array}{l}0 \\
0 \\
0 \\
0 \\
0 \\
0 \\
0 \\
0 \\
0 \\
0 \\
0 \\
0 \\
0 \\
0 \\
0 \\
0 \\
0 \\
0\end{array}$ & 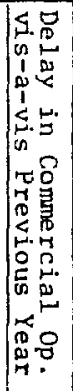 & \multirow[t]{2}{*}{ 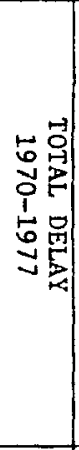 } & \multirow[t]{2}{*}{ 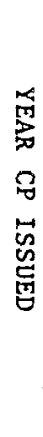 } \\
\hline & \multicolumn{3}{|c|}{1972} & \multicolumn{3}{|c|}{1973} & \multicolumn{3}{|c|}{1974} & \multicolumn{3}{|c|}{1975} & \multicolumn{3}{|c|}{1976} & \multicolumn{3}{|c|}{1977} & & \\
\hline 24. Hartsville 1 & & & & 80 & & & 80 & & & 81 & & 1 & 83 & 1 & 2 & 83 & & & 3 & \\
\hline 25. Hartsville 2 & & & & 81 & & & 81 & & & 82 & & 1 & 84 & 1 & 2 & 84 & & & 3 & \\
\hline 26. Hartsville 3 & & & & 81 & & & 81 & & & 82 & & 1 & 83 & 1 & 1 & 83 & & & 2 & \\
\hline 27. Haresville 4 & & & & 82 & & & 82 & & & 83 & & 1 & 84 & 1 & 1 & 84 & & & 2 & \\
\hline 28. Barton 1 & & & & 82 & & & 84. & & 2 & 83 & & -1 & & & & & & & & \\
\hline 29. Bartan 2 & & & & 83 & & & 85 & & 2 & 84 & & -1 & & & & & & & & \\
\hline 30. Surry 35 & & & & 80 & & & 80 & & & 83 & & 3 & 86 & .5 & 3 & & & & 6 & \\
\hline 31. Surry 4 & & & & 81 & & & 81 & & & 84 & & 3 & 87 & .5 & 3 & & & & 6 & \\
\hline 32. Fermi 36 & & & & 81 & & & & & & & & & & & & & & & & \\
\hline 33. SCE/HTGR 17 & 81 & & & $82^{8}$ & & & 83 & & & & & & & $\cdot$ & & & & & & \\
\hline 34. SCE/HTGR 2 & 82 & & & $83^{9}$ & & & & & & & & & & & & & & & & \\
\hline 35. Quanicasse 1 & & & & 81 & & & & & & & & & & & & & & & & \\
\hline 36. Quanicasse 2 & & & & 82 & & & & & & & & & & & & & & & & \\
\hline 37. Perryman 1 & 79 & & & & & & & & & & & & & & & & & & & \\
\hline 38. Perryman 2 & 80 & & & & & & & & & & & & & & & & & & & \\
\hline $\begin{array}{c}\text { Aggregate Delays } \\
\text { (Years) }\end{array}$ & & & & & & 5 & & & 27 & & & 32 & & & 20 & & & 14 & 98 & \\
\hline
\end{tabular}

1. Announcement Order year are the same for all units except Grand Gulf 1, 2 (71) and AGS 1, 2 (71).

2. Engineering and construction suspended for financlal reasons.

3. United States Government.

4. Construction suspended in November of 1976. Florida Power and Light.

5. Virginia Electric Company $859 \mathrm{MW}, \mathrm{B} \& \mathrm{~W}-\mathrm{PWR}$, announcement was made in September of 1972 . Construction Permit was 1ssued in December of 1974 .

6. Detroft Edison, 1,220 MW, GE-BWR, Portland Oregon was announced Apri1 5, 1972.

7. Desert site, $770 \mathrm{MW}$, announcement made in May of 1972.

8. Vidal 1 .

9. Vidal 2. 
UNITS ORDERED IN 1973

\begin{tabular}{|c|c|c|c|c|c|c|c|c|c|c|c|c|c|c|c|c|c|c|c|c|c|}
\hline $\begin{array}{l}\mathrm{P} \\
\mathrm{L} \\
\mathrm{A} \\
\mathrm{N} \\
\mathrm{T}\end{array}$ & 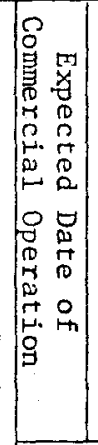 & 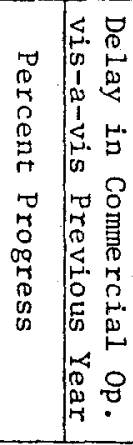 & 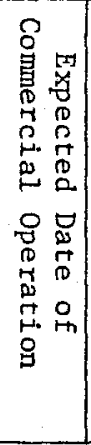 & 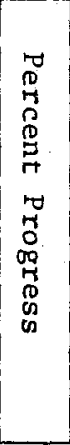 & 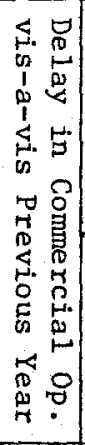 & 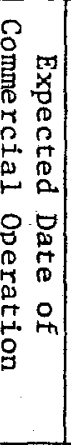 & 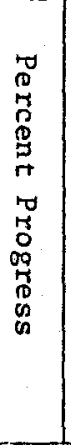 & 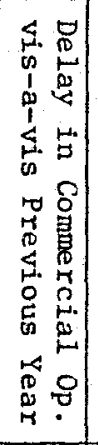 & 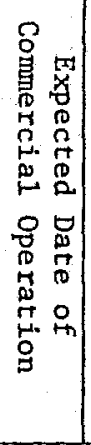 & 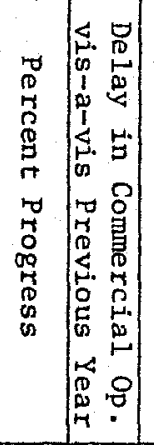 & 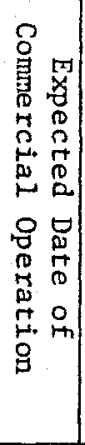 & $\begin{array}{l}0 \\
0 \\
0 \\
0 \\
0 \\
0 \\
0 \\
0 \\
0 \\
0 \\
0 \\
0 \\
0 \\
0 \\
0 \\
0 \\
\end{array}$ & 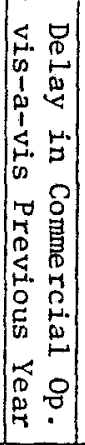 & 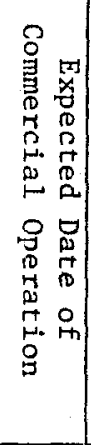 & $\begin{array}{l} \\
\\
0 \\
0 \\
0 \\
0 \\
0 \\
0 \\
0 \\
0 \\
0 \\
0 \\
0 \\
0 \\
0 \\
0 \\
0 \\
0 \\
\\
\end{array}$ & 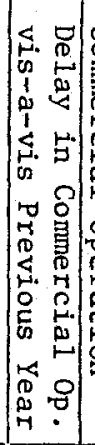 & 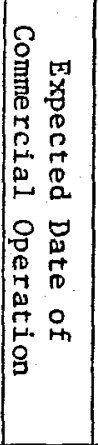 & $\begin{array}{l} \\
0 \\
0 \\
1 \\
0 \\
0 \\
0 \\
0 \\
0 \\
0 \\
0 \\
00 \\
0 \\
0 \\
0 \\
0 \\
\end{array}$ & 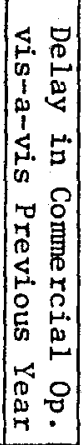 & \multirow[t]{2}{*}{ 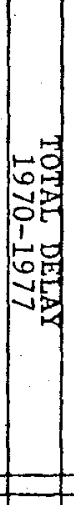 } & \multirow[t]{2}{*}{ 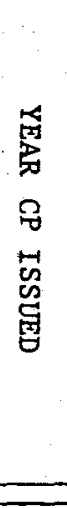 } \\
\hline & \multicolumn{2}{|c|}{1971} & \multicolumn{3}{|c|}{1972} & \multicolumn{3}{|c|}{1973} & \multicolumn{2}{|c|}{1974} & \multicolumn{3}{|c|}{1975} & \multicolumn{3}{|c|}{1976} & \multicolumn{3}{|c|}{1977} & & \\
\hline 1. Clinton 1 & & & & & & 80 & & & 80 & & 81 & & 1 & 81 & 5 & & 81 & & & 1 & 76 \\
\hline 2. Clinton 2 & & & & & & 82 & 83 & & 83 & 1 & 84 & & 1 & 84 & 0 & & 88 & & 4 & 6 & 76 \\
\hline 3. Blue Hills 1 & & & & & & 81 & & & 83 & 2 & 85 & & 2 & 89 & & 4 & 89 & & & 8 & \\
\hline 4. Millstone 3 & & & & & & 80 & & & 80 & & 79 & & -1 & 82 & 10 & 3 & 82 & & & 2 & 74 \\
\hline 5. Pebble Springs 1 & & & & & & & & & 81 & & 83 & & 2 & 85 & & 2 & 85 & & & 4 & \\
\hline 6. Allens Creek 11 & & & & & & 80 & & & 80 & & & & & 85 & & 5 & 85 & & & 5 & \\
\hline 7. Perkins 1 & & & & & & 81 & 83 & & 83 & 1 & 83 & & & 85 & & 2 & 85 & & & 3 & \\
\hline 8. Perkins 2 & & & & & & 81 & 84 & & 85 & 3 & 85 & & & 87 & & 2 & 87 & & & 5 & \\
\hline 9. Perkins 3 & & & & & & 81 & 84 & & 87 & 5 & 87 & & & 89 & & 2 & 90 & & 1 & 8 & \\
\hline 10. Cherokee 1 & & & & & & 82 & 84 & & 84 & 1 & 84 & & & 84 & $<1$ & & 84 & & & 1 & \\
\hline 11. Cherokee 2 & & & & & & 82 & 84 & & 86 & 3 & 86 & & & 86 & $<1$ & & 86 & & & 3 & \\
\hline 12. Cherokee 3 & & & & & & 82 & 84 & & 88 & 5 & 88 & & & 88 & $\angle 1$ & & 89 & & 1 & 6 & \\
\hline 13. Jamesport 1 & & & & & & 81 & & & 81 & & 82 & & 1 & 83 & & 1 & 84 & & 1 & 3 & \\
\hline 14. Future 12 & & & & & & & & & 81 & & 83 & & 1 & 85 & & 2 & 87 & & 2 & 5 & \\
\hline 15. Future 2 & & & & & & & & & 82 & & 84 & & 2 & 87 & & 3 & 89 & & 2 & 7 & \\
\hline 16. South Texas 1 & & & & & & 80 & & & 80 & & 80 & & & 80 & 2.5 & & 80 & & & 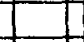 & 75 \\
\hline 17. South Texas 2 & & & & & & 82 & & & 82 & & 82 & & & 82 & $<1$ & & 82 & & & & 75 \\
\hline 18. WPPSS 3 & & & & & & 81 & & & 81 & & 81 & & & 83 & & 2 & 83 & & & 2 & \\
\hline 19. River Bend 2 & & & 81 & & & 82 & & & 82 & & 83 & & & 83 & 1 & & 85 & & 2 & 2 & 77 \\
\hline 20. Palo Verde 1 & & & & & & 81 & & & 81 & & 82 & & 1 & 82 & & & 82 & & & 1 & 76 \\
\hline 21. Palo Verde 2 & & & & & & 83 & 5 & & 82 & -2 & 84 & & 2 & 84 & & & 84 & & & & 76 \\
\hline 22. Palo Verde 3 & & & & & & 83 & 5 & & 84 & & 86 & & 2 & 86 & & & 86 & & & 2 & 76 \\
\hline 23. 1990 Unit $^{3}$ & & & & & & 85 & & & 90 & 5 & 90 & & & 90 & & & 90 & & & 5 & \\
\hline 24. 1992 Unit & & & & & & 86 & & & 92 & $\frac{6}{6}$ & 92 & & & 92 & & & 92 & & & 6 & \\
\hline
\end{tabular}


-CONTINUED-

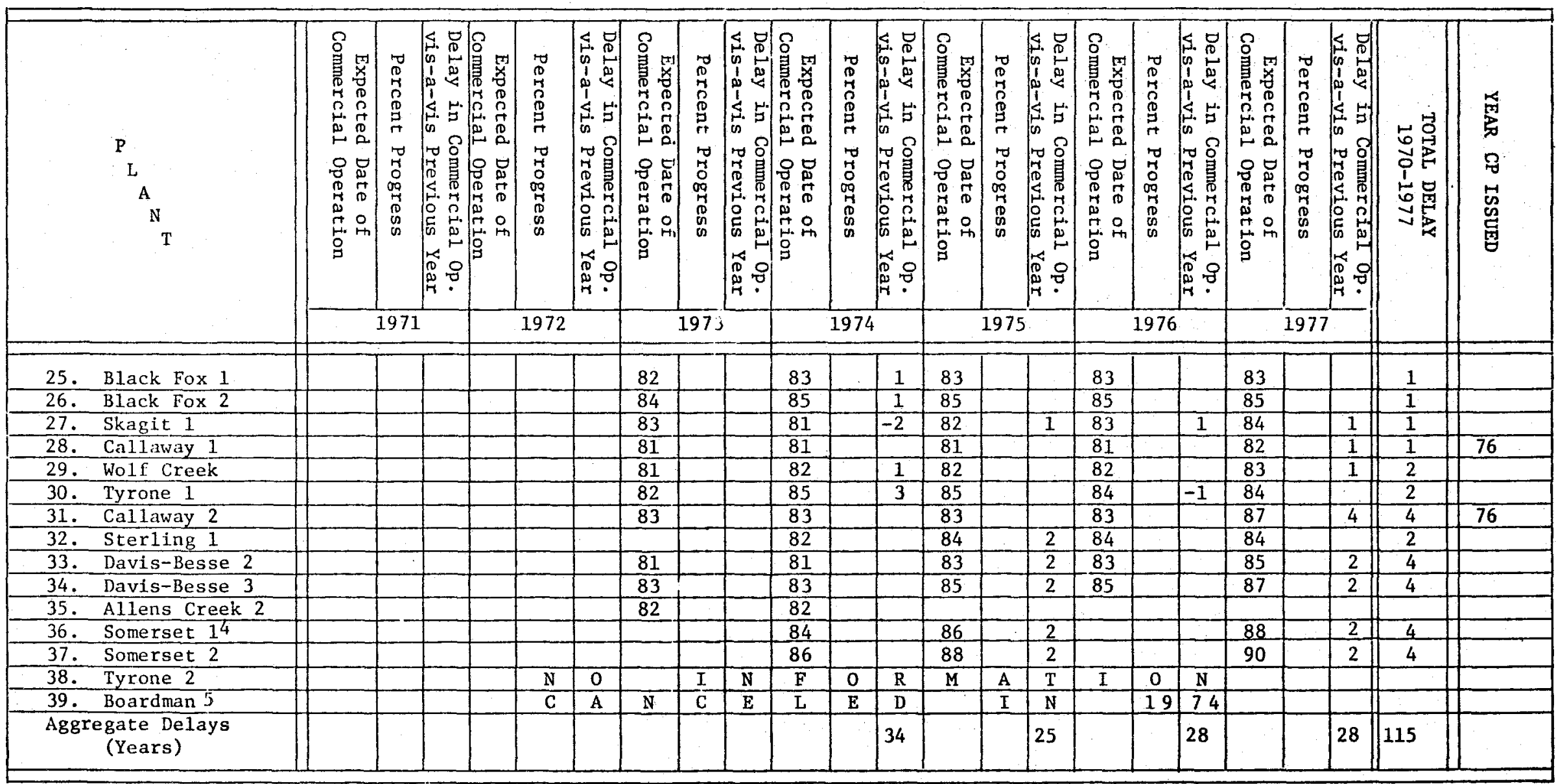

1. Units 1 and 2 were deferred in September of 1975. Unit 1 was reactivated in October of 1976. Unit 2 was canceled.

2. Formally Koshkonong 1, 2, alternative sites under consideration.

3. Corresponds to former AGS 3, 4 .

4. NYSG \& E, $1200 \mathrm{MW}, \mathrm{GE}-\mathrm{BWR}$, announced 7/13/73, later known as Nuclear Unit 1, 2 (New York).

5. Portland GE, $1260 \mathrm{MW}, \mathrm{B} \& \mathrm{~W}-\mathrm{PWR}$, Portland Oregon was announced on February 16, 1972. 
APPENDTX C

UNITS ORDERED IN 1974

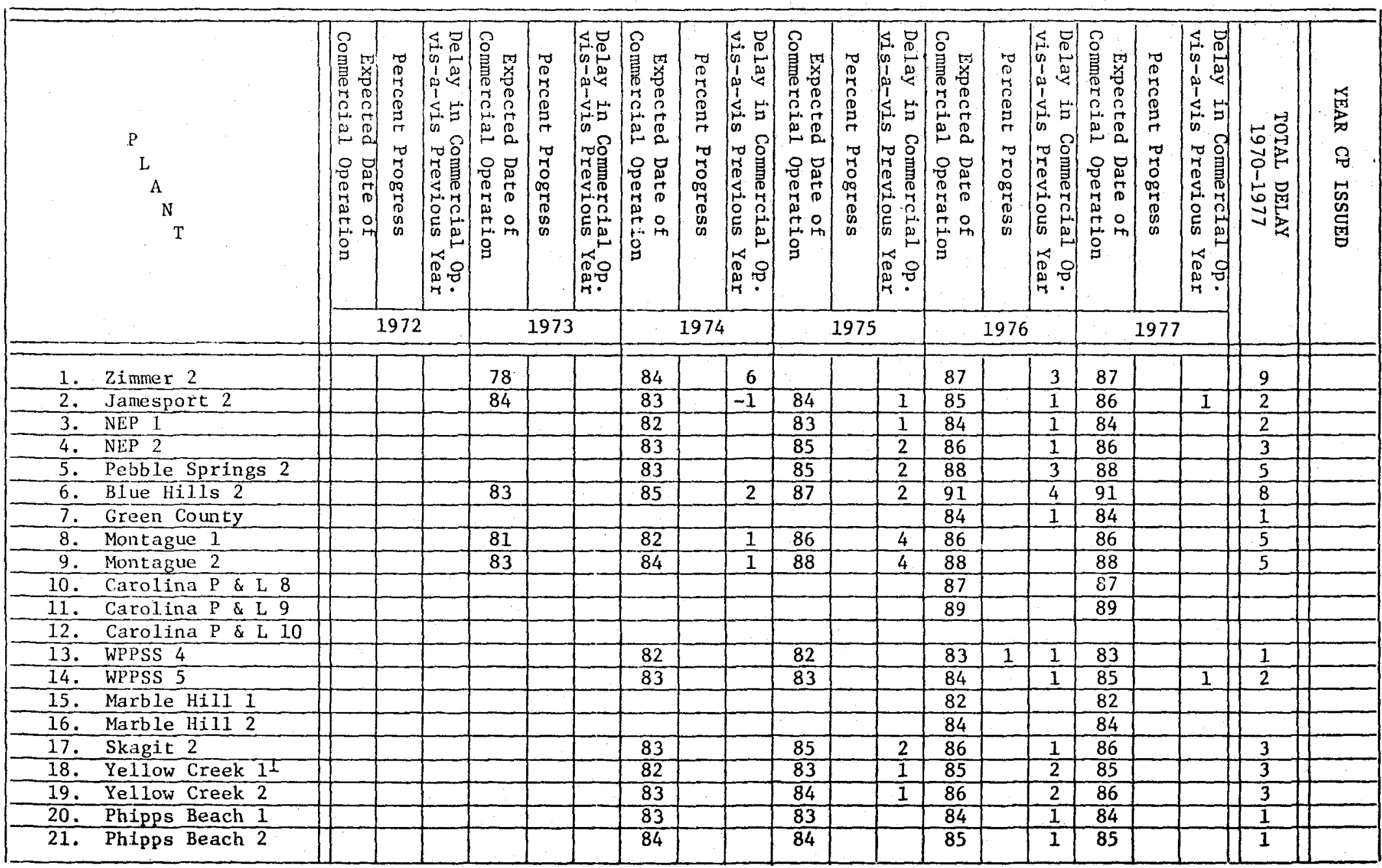


APPENDIX C

UNITS ORDERED IN 1974

-CONT INUED-

\begin{tabular}{|c|c|c|c|c|c|c|c|c|c|c|c|c|c|c|c|c|c|c|c|c|}
\hline $\begin{array}{l}\mathrm{P} \\
\mathrm{L} \\
\mathrm{N} \\
\mathrm{T}\end{array}$ & 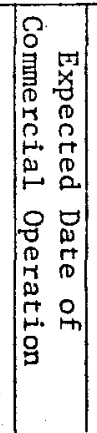 & 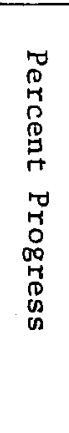 & 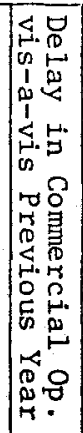 & 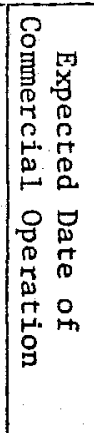 & $\begin{array}{c} \\
0 \\
0 \\
7 \\
0 \\
0 \\
0 \\
0 \\
0 \\
0 \\
00 \\
0 \\
0 \\
0 \\
0\end{array}$ & 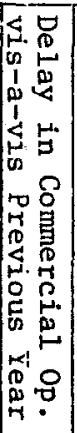 & $\mid \begin{array}{ll}0 & \\
0 & \\
1 & 0 \\
0 & 0 \\
0 & 0 \\
0 & 0 \\
0 & 0 \\
0 & 0 \\
0 & 0 \\
0 & 0 \\
0 & 0 \\
0 & 0 \\
0 & 0 \\
0 & 0 \\
0 & m \\
0 & \end{array}$ & 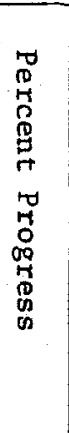 & 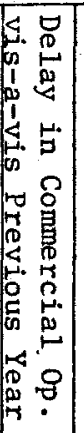 & 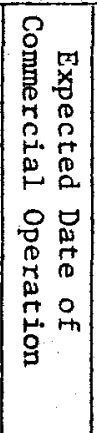 & $\begin{array}{l} \\
0 \\
0 \\
0 \\
0 \\
0 \\
0 \\
0 \\
0 \\
0 \\
0 \\
0 \\
0 \\
0 \\
0 \\
0 \\
0 \\
\end{array}$ & 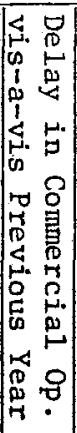 & 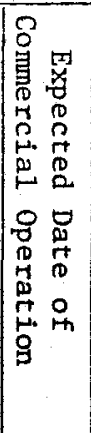 & $\begin{array}{l}0 \\
0 \\
0 \\
0 \\
0 \\
0 \\
0 \\
0 \\
+1 \\
0 \\
0 \\
0 \\
0 \\
0 \\
0 \\
0 \\
0 \\
0 \\
0 \\
0\end{array}$ & 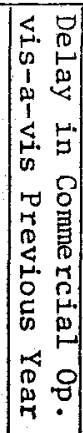 & 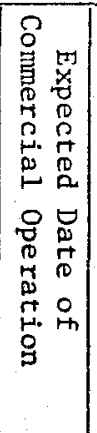 & $\begin{array}{l}\overrightarrow{0} \\
0 \\
0 \\
0 \\
0 \\
ت \\
\overrightarrow{0} \\
0 \\
\overrightarrow{0} \\
0 \\
0 \\
0 \\
0 \\
0\end{array}$ & 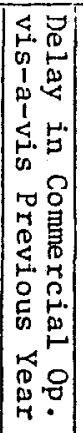 & \multirow[t]{2}{*}{ 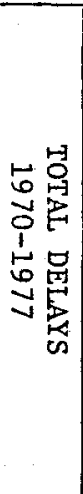 } & \multirow[t]{2}{*}{ 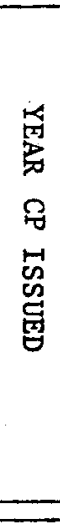 } \\
\hline & \multicolumn{3}{|c|}{1972} & \multicolumn{3}{|c|}{1973} & \multicolumn{3}{|c|}{1974} & \multicolumn{3}{|c|}{1975} & \multicolumn{3}{|c|}{1976} & \multicolumn{3}{|c|}{1977} & & \\
\hline 22. Fort Calhoun 2 & & & & & & & & & & 83 & & & 83 & & & 83 & & & & \\
\hline 23. NORCO-NP 1 & & & & & & & 81 & & & 85 & & & & & & & & & & \\
\hline 24. Sears Island & & & & & & & & & & 84 & & & 86 & & 2 & & & & 2 & \\
\hline 25. Barton 3 & & & & & & & 85 & $\mathrm{C}$ & A & $\mathrm{N}$ & $\mathrm{C}$ & $\mathrm{E}$ & $\mathrm{L}$ & $E$ & $\mathrm{D}$ & & 19 & 76 & & \\
\hline Barton 4 & & & & & & & 86 & $\mathrm{C}$ & $\bar{A}$ & $\mathbf{N}$ & $\mathrm{C}$ & E & $\mathrm{L}$ & E & D & & 19 & 76 & & \\
\hline 27. Florida Power 2 & & & & & & & * & C & $\bar{A}$ & $\mathbf{N}$ & $\mathrm{C}$ & $\bar{E}$ & $\mathrm{~L}$ & E & $\mathrm{D}$ & & 19 & 76 & & \\
\hline 23. Florida Power 3 & & & & & & & * & $\mathrm{C}$ & A & $\mathbf{N}$ & $\mathrm{C}$ & $\mathrm{E}$ & $\overline{\mathrm{L}}$ & $\bar{E}$ & $\mathrm{D}$ & & 19 & 76 & & \\
\hline 29. Iowa Power and Light & & & & & & & 83 & $\mathrm{C}$ & A & $\mathrm{N}$ & $\mathrm{C}$ & $E$ & $\mathrm{~L}$ & $E$ & D & & 19 & 76 & & \\
\hline 30. St. Rosalie 1 & & & & & & & 82 & $\bar{c}$ & A & N & $\mathrm{C}$ & $\bar{E}$ & $\overrightarrow{\mathrm{L}}$ & $\mathrm{E}$ & $\bar{D}$ & & 19 & 75 & & \\
\hline 31. St. Rosalie 2 & & & & & & & 84 & & & & & & & & & & & & & \\
\hline 32. Off fhore $1 \& 2$ & & & & $\mathrm{C}$ & $\mathrm{A}$ & $\mathbf{N}$ & C & $E$ & $\mathrm{~L}$ & $E$ & $\mathrm{D}$ & & & & & & & & & \\
\hline $\begin{array}{c}\text { Aggregate Delays } \\
\text { (Years) }\end{array}$ & & & & & & & & & 9 & & & 20 & & & 25 & & & 2 & 56 & \\
\hline
\end{tabular}

1. Site moved from Atlanta to Mississippi.

${ }^{\star}$ Indefinite.

2. Site undetermined. 

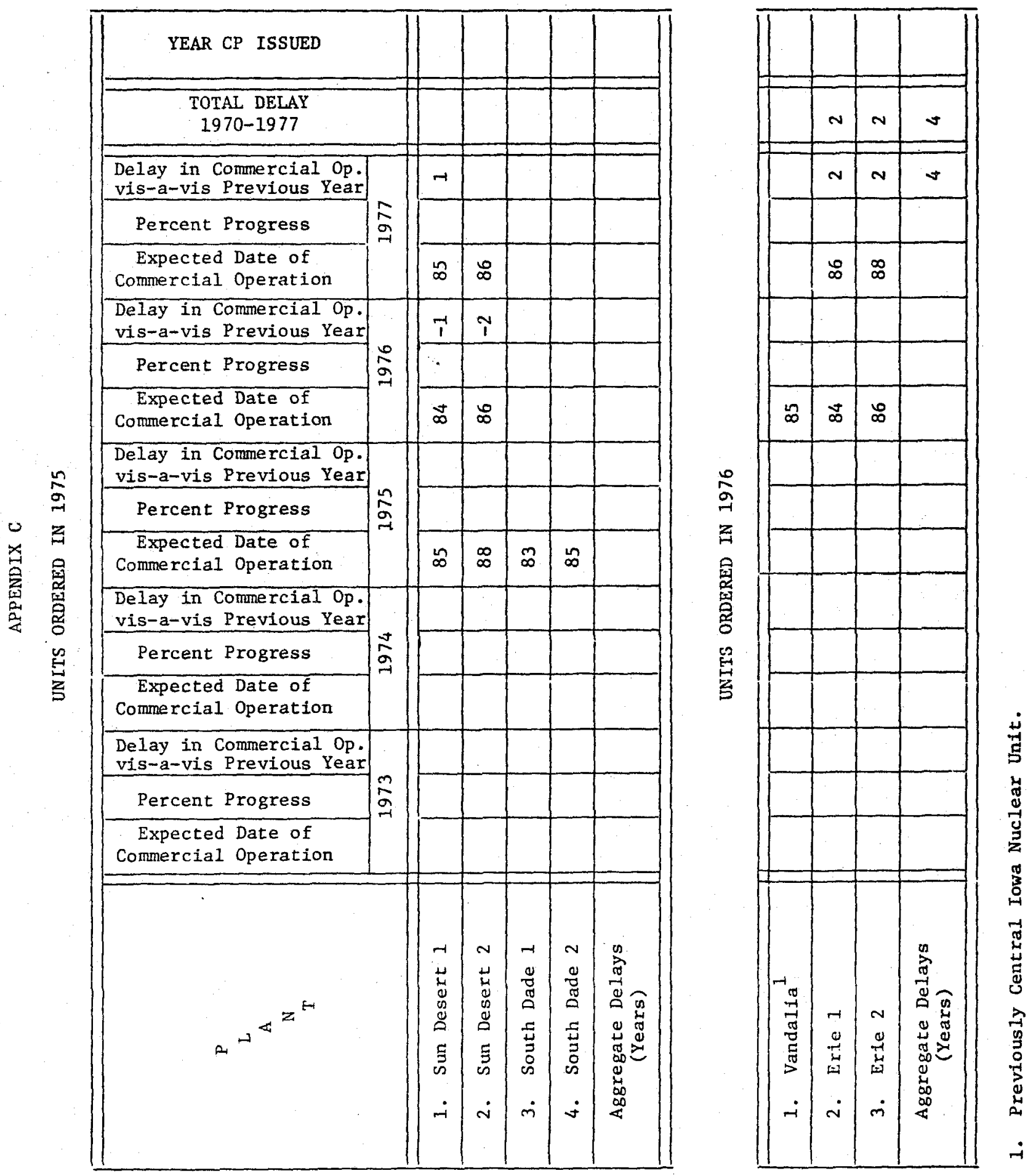


\section{BIBLIOGRAPHY}

Atomic Energy Commission, "Power Plant Capital Costs: Current Trends and Sensitivity to Economic Parameters," WASH-1345, Washington, October 1974.

Bupp, I., Derian, J., Donsimoni, M., Treite1, R., "Trends in Light Water Reactor Capital Costs in the United States: Causes and Consequences," CPA-74-8, December 1974, Center for Policy A1ternatives, Massachusetts Institute of Technology, Cambridge, Massachusetts.

Brush, H., 1977 Update, Power Plant Economics, Bechtel Power Corporation, January $21,1976$.

Burness, H. Stuart, Montgomery, W. David and Quirk, James P., "The Turnkey Era in Nuclear Power," Social Science Working Paper No. 175, California Institute of Technology, August 1977.

Davis, W., Economics of Nuclear Power, Bechtel Power Corporation, January 13, 1975. 
Edison Electric Institute, "The Edison Electric Institute's Comments and Critique of the Council on Economic Priorities Report Power Plant Performance and its Iater Update," July 1977.

Komanoff, C., Power Plant Performance: Nuclear And Coal Capacity Factors and Economics, Council of Economic Priorities, New York, 1976.

Mooz, W., "A Cost History of the Light Water Reactor," WN-9494-NSF Rand, November 1976.

Perry, Robert, et al., "Development and Commercialization of the Light Water Reactor, 1946-1976," R-2180-NSF, Rand Corporation, June 1977. 